\title{
CITY OF SAN LUIS OBISPO OPEN SPACE VEGETATION MANAGEMENT PLAN
}

\author{
A Professional Project \\ presented to \\ the Faculty of California Polytechnic State University, \\ San Luis Obispo
}

\author{
In Partial Fulfillment \\ of the Requirements for the Degree \\ Master of City and Regional Planning
}

by Danielle Rose Althaus

June 2014 
(C)2014

Danielle Rose Althaus

ALL RIGHTS RESERVED 
TITLE:

AUTHOR:

DATE SUBMITTED:

COMMITTEE CHAIR:

COMMITTEE MEMBER:

COMMITTEE MEMBER:
City of San Luis Obispo Open Space Vegetation Management Plan

Danielle Rose Althaus

June 2014

W. David Conn, D. Phil.

Professor, City and Regional Planning

Kenneth C. Topping, AICP

Lecturer, City and Regional Planning

Robert Hill

Natural Resources Manager,

City of San Luis Obispo 


\begin{abstract}
City of San Luis Obispo Open Space Vegetation Management Plan

Danielle Rose Althaus
\end{abstract}

This Master's Professional Project is focused on the development of a draft Vegetation Management Plan for the City of San Luis Obispo Open Space properties. The purpose of the plan is to provide a comprehensive document which identifies how the city is addressing wildfire preparedness in city-owned open space properties. Methods used in plan development include a literature review, content analysis, geographic information systems (GIS), a course audit, and consultation with city staff and other stakeholders. Each open space property is identified in the plan, describing its location, vegetation, topography, assets, access points, water supply, evacuation routes, historical fire data, predominant risk exposure, current wildfire preparedness plan, priority ranking, and a proposed implementation plan. 


\section{ACKNOWLEDGMENTS}

This project would not have been possible without motivation from Rodger Maggio and Robert Hill. I would like to thank the both of you for your continuous encouragement and support throughout this process. I would also like to thank my Committee Chair, David Conn, for his advice, constructive criticism, and praise. A special thank you to Ken Topping for his expertise and input on the development of this project. Lastly, thank you to Daniel Turner for allowing me to audit your course about WildlandUrban Fire Protection which helped me significantly in comprehensively understanding the fundamentals of wildfire preparedness and firefighting. 


\section{TABLE OF CONTENTS}

LIST OF FIGURES.

viii

\section{CHAPTER}

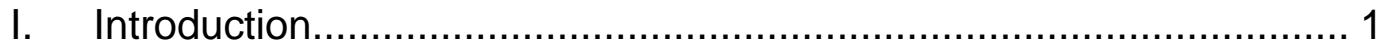

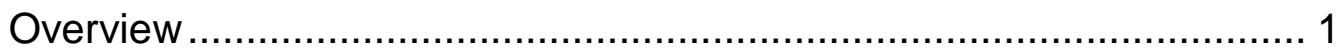

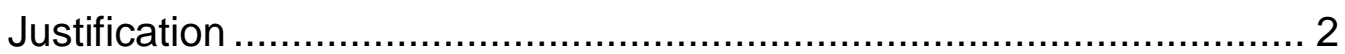

Theoretical Framework ................................................................. 4

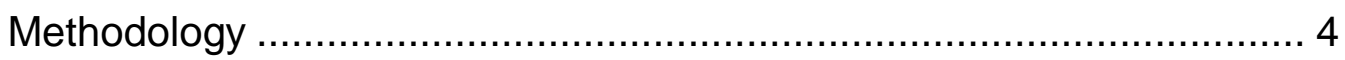

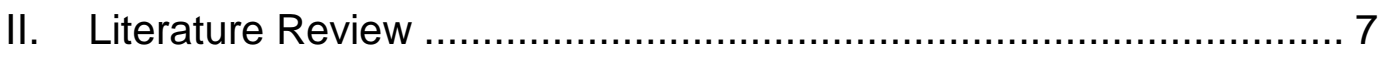

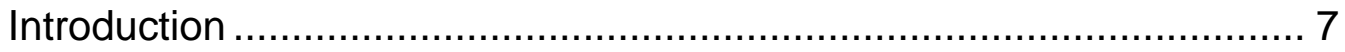

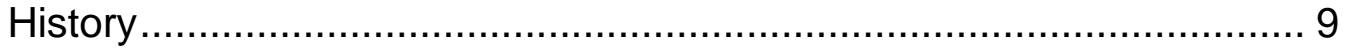

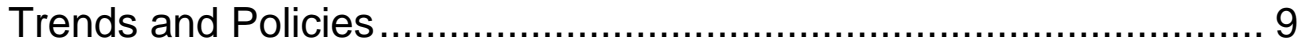

Wildfire Preparedness and Planning ......................................... 12

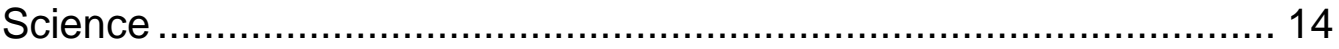

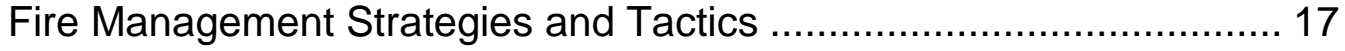

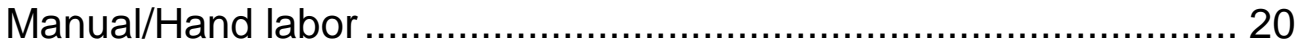

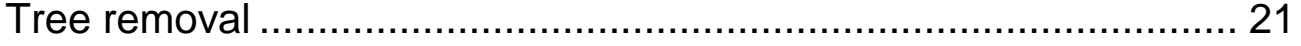

Mechanical ......................................................................... 21

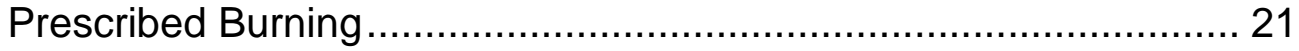

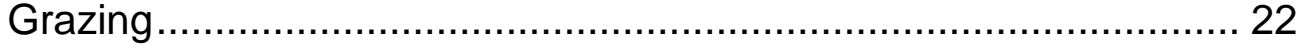

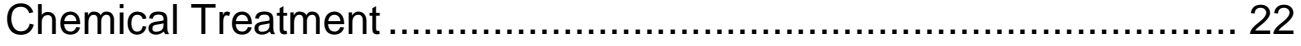

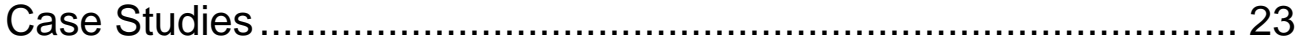

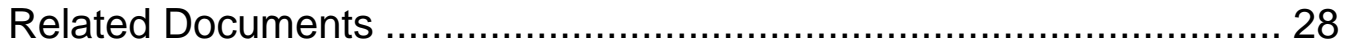

San Luis Obispo General Plan ................................................. 28

Conservation Guidelines for Open Space Lands, City of San Luis

Obispo ............................................................................. 31

Conservation Plans, City of San Luis Obispo ................................ 32

Local Hazard Mitigation Plan, City of San Luis Obispo ................... 33

Local Hazard Mitigation Plan, County of San Luis Obispo ............... 35

Community Wildfire Protection Plan, County of San Luis Obispo..... 36 
III. Discussion of Lessons Learned and Recommendations ................. 38

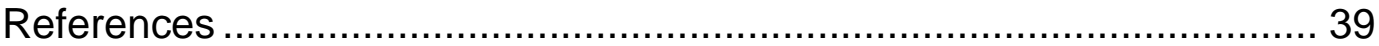

Appendix A: City of San Luis Obispo Open Space Vegetation

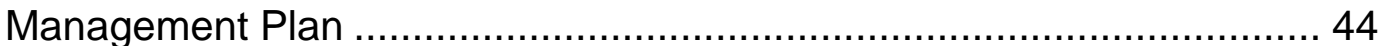




\section{LIST OF FIGURES}

Figure 1. Fire Hazard Severity Ranking of Fuels..........................16 


\section{Introduction}

\section{Overview}

The City of San Luis Obispo is located in San Luis Obispo County on the Central Coast of California, with a population of about 45,000 people (U.S. Census Bureau, 2010 Census). There are 12 large open space lands totaling about 4,000 acres, as well as additional conservation easements, all operated by the City. The Conservation and Open Space Element of the General Plan requires that each Open Space in San Luis Obispo have its own Open Space Conservation Plan, and that each of those plans shall contain a Wildfire Preparedness Plan. The content developed for each open space in the Management Plan is consistent with General Plan, and is contributing to, deriving information from, and adding to the Wildfire Preparedness Plan sections in the Conservation Plans for each Open Space.

The final product is a comprehensive Vegetation Management Plan for the City of San Luis Obispo's Open Spaces. There is geographic mapping of the open spaces, including but not limited to: vegetation maps, fire hazard severity zones, access routes, and fire hydrants. The Management Plan discusses each Open Space, its assets, vegetation, and a management program, as well as any other relevant information. 
The Management Plan is consistent with the San Luis Obispo General Plan and Conservation Plans. It also contains criteria for evaluation of Open Spaces and determination of an implementation plan with a priority ranking of objectives.

\section{Justification}

Wildfire management is an important topic and pertinent to the field of City and Regional Planning. Current literature suggests that wildfires are becoming increasingly frequent and destructive to lives and property, while costing millions of dollars annually. Climate change is also heightening the likelihood of wildfires occurring, specifically with longer periods of drought and hotter weather expected in California (City of San Luis Obispo, 2014).

Residential development is continuously encroaching on wildland areas already at risk for wildfires; these areas are known as the WildlandUrban Interface ("WUI"). The California Fire Safe Council defines Wildland-Urban Interface as "Any area where wildland fuels threaten to ignite combustible homes and structures. The location where humans and their development meet or are intermixed with wildland fuels" (California Fire Safe Council, 2013). Suppression of wildfires has remained the default method of management in the WUI, even though suppression 
allows wildfires to eventually become more catastrophic and is "turning the American West into a tinderbox" (Tullis, 2013). Wildfires have been brought to national attention in most recent years, with major fires in California, Arizona, and Colorado. A news article recently reported that "wildfires across America brought 1,093 primary residences across the country to cinders in 2013. In total, 32 percent of U.S. homes lie in danger of falling prey to the flames of a wildfire, according to the National Interagency Fire Center in Boise, Idaho, - and it is almost a certainty that some of those homes will be threatened this year" (Roach, 2014, p.1). Additionally, it is important to collaborate with local agencies, community members, and other potential stakeholders in order to properly plan for the prevention and management of wildfires with the purpose of protecting lives, property, and resources.

This is an ideal time for the development of a Management Plan for a number of reasons. The City of San Luis Obispo recently updated its Local Hazard Mitigation Plan (LHMP) and the County of San Luis Obispo is updating its Community Wildfire Protection Plan (CWPP). In addition, the Fire Department is required to make a Vegetation Management Plan for the City in order to fulfil insurance requirements, as well as completing steps in the LHMP and CWPP process. Lastly, the Conservation and Open Space Element of the General Plan requires each Open Space to have a Wildfire Preparedness Plan, which some of the Open Spaces do 
not currently have, and the Management Plan can provide useful information to begin the process of developing those plans.

\section{Theoretical Framework}

This project builds on theory developed in the fields of wildfire preparedness and planning.

\section{Methodology}

The methods that were used in developing the Vegetation Management Plan were as follows:

1. Literature review of relevant theories and practices for wildfire preparedness. Case studies of existing Wildfire Preparedness and Vegetation Management Plans and Guidelines.

2. Content analysis of the following documents, so as to remain consistent between the policies, guidelines, and background information:

a. City of San Luis Obispo General Plan

b. Conservation Guidelines for Open Spaces in the City of San Luis Obispo 
c. Conservation Plans, City of San Luis Obispo:

i. Bishop Peak Natural Reserve

ii. Cerro San Luis Conservation Plan

iii. Irish Hills Conservation Plan

iv. Johnson Ranch Conservation Plan

v. South Hills Conservation Plan

vi. Stenner Springs Natural Reserve Draft Conservation Plan

vii. Reservoir Canyon Natural Reserve Conservation Plan

d. Local Hazard Mitigation Plan, City of San Luis Obispo

e. Local Hazard Mitigation Plan, County of San Luis Obispo

f. Community Wildfire Protection Plan, County of San Luis Obispo

3. Consultation with City Staff and other stakeholders, including:

a. Regular meetings with the City of San Luis Obispo Natural Resources Manager and the City of San Luis Obispo Fire Marshall.

b. Attendance at meetings on the update of the San Luis Obispo County Community Wildfire Protection Plan.

c. Attendance at meetings on the update of the San Luis Obispo Local Hazard Mitigation Plan.

4. Course Audit of NR 455: Wildland-Urban Fire Protection, taught by Professor Daniel Turner 
5. Geographic Information Systems: Utilized Geographic Information Systems to analyze fire history, vegetation, access, fire station locations, assets, fire hazard severity zones, trails, and any other information that was necessary.

6. There were two sections of the Vegetation Management Plan which were completed by the City of San Luis Obispo Fire Marshall, Rodger Maggio:
a. Overview of the City of San Luis Obispo
b. Fire Department Overview 


\section{Literature Review}

\section{Introduction}

This literature review focuses on wildfire preparedness and the wildland urban interface from a hazard mitigation perspective, addressing: what hazard mitigation is and why hazard mitigation is necessary; the history of wildfires in the United States and its relevance to planning; the science behind wildfires; fire management strategies and vegetation management plan guidelines; relevant documents and plans addressing wildfire preparedness; and important principles and lessons for planners, such as assessment and implementation measures that can and are being taken in order to mitigate the impact of wildfires.

Proactive mitigation strategies are needed for multiple reasons and are addressed in the book Managing Fire in the Urban Wildland Interface. These reasons are:

- "Recommendations after significant past fires are not being translated into viable solutions;

- Suppression alone is not sufficient; [and]

- Destructive impacts to the community and the environment from UWI fire are significant" (Blonski, Miller \& Rice, 2010, p.8). 
Therefore, there is a need for improved proactive planning and policies to plan for wildfire management and mitigation.

There are four steps in hazard planning: preparedness, mitigation, response, and recovery. Preparedness is "the range of deliberate, critical tasks and activities necessary to build, sustain, and improve the operational capability to prevent, protect against, respond to, and recover from incidents" (Federal Emergency Management Agency [FEMA] 2011a, p.4.2). The next component is Mitigation, which is aimed to reduce or eliminate risk and reduce potential effects of an incident. The third component is Response, which follows an incident that occurred and addresses the "short-term, direct effects of an incident" (FEMA, 2011a, p.4.11). The final phase of hazard planning is Recovery, in which the goal is "to return the community's systems and activities to normal" (FEMA, 2011a, p. 4.14). A Vegetation Management plan is a step in the Mitigation phase, which FEMA defines as the "process used to identify risks and vulnerabilities associated with natural disasters and to develop long term strategies for protecting people and property in future hazard events" (FEMA, 2011b). It is important to utilize each step as necessary, but localities can be better equipped to minimize impacts of disasters with Mitigation planning.

Hazard mitigation is essential for a number of reasons. First of all is for the protection of lives, property, and resources. One report states that "between 1985 and 1994 more than 9,000 homes were destroyed and 
cost on average 300 million per year" (Fried, Torn \& Mills, 2004). In addition, with development continuing to encroach on the wildland urban interface, more land is at stake. A study done by CoreLogic, a California financial research company, found that 10 million of the 17 million homes that were built between 1990 and 2008 were in the WUI (Weeks, 2012). There are also numerous benefits of mitigation planning, such as: increased public awareness and support for mitigation actions; money saved through regulatory actions; and the development of partnerships with diverse stakeholders and expanding resources (FEMA, 2012b).

\section{History}

\section{Trends and Policies}

Trends in wildfire management have shifted in the United States throughout history. In the late $19^{\text {th }}$ century, a number of massive wildfires throughout the Midwest gained national attention, and in the beginning of the early $20^{\text {th }}$ century, there was a movement of the Bureau of Land Management and the National Forest Service taking over lands, obtaining most of the wildfire prone lands in the country. After a drought in 1910, there were a series of wildfires that exploded and 4 million acres burned in Washington, Oregon, Montana, Idaho, California, South Dakota, and Nebraska, after which the CCC and the National Forest Service took a stance on full suppression and attempted to put out every single fire 
(Schwab, Meck \& Simone, 2005). However, wildfires help to naturally burn off the fuel load of dead materials on the forest floor; therefore, when the fires are suppressed and the fuel load is building up instead of being burned off, any ignition can be incredibly dangerous and produce a strong fire. As Busenberg (2004) points out: "in essence, this choice focused attention on wildfire suppression while failing to focus attention on wildland fuel reduction" (p. 150).

Since the 1950's, development has been continuously encroaching in the wildland urban interface, increasing the threat of wildfires affecting development throughout the United States. Consequently, massive wildfires have been destroying lives and property and costing millions of dollars, particularly in California, where "between 2003-2012, an average of \$400 million was spent annually fighting wildfires" (Kenward \& Raja, 2013, para. 3). Busenberg (2004) argues that "for more than nine decades, the central goal of American wildfire policy was to protect natural resources and human communities from damages caused by wildfires. Yet the consequences of this wildfire policy greatly increased the risk of wildfire damages in America" (p. 145).

Starting in the 1960s, attitudes began to shift as conservationists argued that wildfires could play a beneficial role in ecosystems, and in 1978 the Forest Service changed policy from controlling and suppressing to managing wildfires (Weeks, 2012). Some of the benefits of forest fires are pest control, removal of non-native species, nutrients from ashes, 
removal of undergrowth, and increased fire dependent species (National Park Service, 2014).

Prescribed burns, also known as controlled burns, were adopted as policies in the 1990's. Prescribed burning has some advantages and disadvantages, and it requires adequate resources, as well as the trust and awareness of a surrounding community. Trust and resources are both critical factors, particularly after 2000 , due to the "prescribed burns at National Park Service sites in Arizona and New Mexico expand[ing] out of control," causing a review of the fire hazards in the WUI, and deeming the risks '“more complex and extensive' than understood in the original fire plan" (Weeks, 2012, p. 951-953).

The 2000's are facing problematic times with drought, development increase, and more intense fires. In 2003 there were 739,000 acres burned and 3,600 homes lost in California (Reams, Haines, Renner, Wascom \& Kingre, 2005). As Weeks (2012) states, "Record-setting heat and intense drought have made 2012 one of the worst wildfire seasons in a decade of intense fires. Climate change, residential development in fireprone rural areas and the impact of past firefighting policies have combined to put many areas of the United States at risk, especially in the West" (p. 941). Wildfires have been brought to national attention in most recent years, with major fires in California, Arizona, and Colorado. An NBC News article recently reported that: "Wildfires across America brought 1,093 primary residences across the country to cinders in 2013. In 
total, 32 percent of U.S. homes lie in danger of falling prey to the flames of a wildfire, according to the National Interagency Fire Center in Boise, Idaho, - and it is almost a certainty that some of those homes will be threatened this year" (Roach, 2014, p.1). In addition, experts say that wildfires are a heightened threat due to climate change making areas hotter and drier, fuel buildup from continuous suppression instead of allowing smaller fires to burn naturally, and people moving from cities into fire-prone areas and still expecting the protection of their property (Weeks, 2012, p.943). Additionally, as Busenberg (2004) stated: "the success of ... a fuel reduction program may well depend on a process of learning and adaptation overtime" (p. 153). Furthermore, there are many fuel management strategies available in addition to prescribed burning, and these approaches are best selected on a case by case basis and are further examined in the "Fire Management Strategies" section of this document. Flexibility and adaptation are necessary for successful policies and plans for wildfire preparedness.

\section{Wildfire Preparedness and Planning}

Various laws and regulations have been passed regarding hazard mitigation and wildfire preparedness that pertain to planning. To start with, the Federal Disaster Mitigation Act of 2000 (DMA 2000) provides the "legal basis for FEMA mitigation planning requirements for state, local, and Indian tribal governments as a condition of mitigation grant 
assistance" (FEMA, 2013, para. 1). The DMA 2000 requires localities to adopt a Local Hazard Mitigation Plan (LHMP) in order to obtain grant eligibility. FEMA is the Federal Emergency Management Agency, and its mission as stated on its website is: "to support our citizens and first responders to ensure that as a nation we work together to build, sustain, and improve our capability to prepare for, protect against, respond to, recover from, and mitigate all hazards" (FEMA, 2012a, para. 1). The LHMP that is required to obtain eligibility for grants must include: a planning process, an assessment of risks, a mitigation strategy, and a plan maintenance and updating process (California, State of, 2003a). In addition to the LHMP, California requires a Safety Element as part of the General Plan. The goal of the Safety Element is to "reduce the potential risk of death, injuries, property damage, and the economic and social dislocation resulting from hazards" (California, State of, 2003a, p. 90). The Safety Element is used to develop action oriented policies and implementation measures that should correspond with the data collected, and other examples such as access and evacuation routes, road and structural identification, roadway widths, and water supply. An example of a policy that might appear in the Safety Element is that "no development shall be approved unless the local government can make a finding that development can be reasonably accessed and served in the case of a wildfire" (California, State of, 2003b, p. 8). 
Mitigation strategies may be addressed in multiple documents, yet they must still remain consistent throughout all of them. Some examples of common mitigation strategies include prevention methods, reduction of impacts, property protection, and response actions. An important method of prevention is educating the public, such as informing residents about why certain codes and ordinances are in place, which can help to gain support for planning policies as well as guide responsible behavior. Some other mitigation options are fuel reduction, fire-safe building standards, proper land use planning, and increase of fire suppression response capabilities of the fire department (Schwab, Meck, \& Simone, 2005, p. 54).

There are many guidelines and websites available to planners, such as those produced by The Governor's Office of Planning and Research, FireWise.org, and FEMA, all of which can greatly assist with assessment and mitigation measures that can be implemented in a community.

\section{Science}

In order to effectively manage wildfires, it is essential to understand the fundamentals behind fire. There are some important aspects to comprehend when learning about wildfires, such as the physics or 
components that make fire, elements that influence in the spread of wildfires, and the types of fire spread.

The physics of fire is basic, as fire requires only three things to burn: oxygen, fuel, and heat. This is known as the "Fire Triangle." In order to suppress a fire, one of those three components needs to be eliminated, such as reducing heat by applying water (Blonski et al., 2010). The flammability of vegetation (fuel) can vary among different types. An example is that fires involving eucalyptus trees are easily intensified due to an oily resin in the tree; in contrast, there are species such as dogwood which are fire resistant (Schwab, Meck \& Simone, 2005). It is important to note that the fuel that works well in igniting a fire (such as dry wood) is not necessarily what is needed to sustain a fire once it is going strong. This knowledge can be used when assessing the landscape and surrounding ecosystem in order to plan, such as using certain landscaping practices in mitigation.

There are three elements that influence the spread of wildfires: fuel, topography, and weather (Blonski et al., 2010). Fuel is whatever can burn, such as trees or houses, and it varies and can strengthen or deplete a fire's strength. For example, there are light fuels such as grasses and twigs, medium fuels such as fences and shrubs, and heavy fuels such as trees and homes (Blonski et al., 2010). There can also be breaks in fuel, such as an area that was previously burned and has not recovered yet, in which case there can be a decrease in the spread of the fire. Another 
factor that contributes to the spread of wildfires is topography, or the natural features of a landscape. Fire moves faster uphill when there are steep slopes or saddles; therefore, steep topography is another important factor when assessing hazards. A final element that can affect the spread of wildfires is weather, specifically in terms of temperature, humidity, and wind (FEMA, 2001). Figure 1 reproduces a table from the FEMA How-To Guide (2001), which can be used as an example to evaluate whether the wildfire hazard risk is moderate, high, or extreme based on these factors.

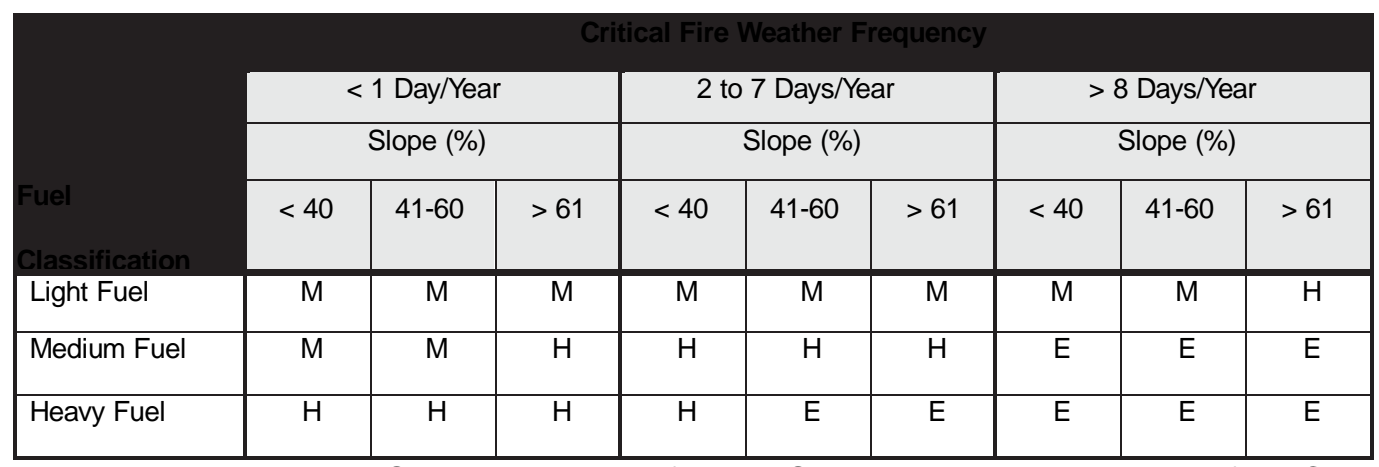

Figure 1. Fire Hazard Severity Ranking of Fuels. Source: Urban Wildland Interface Code: 2000. $M=$ Moderate hazard $H=$ High hazard $E=$ Extreme hazard. Retrieved from:

(Federal Emergency Management Agency, 2001)

Additionally, there are different types of fire spread: ground fires, surface fires, and crown fires. Ground fires burn in litter and roots below the ground level; surface fires burn in grasses and shrubs, may move rapidly, and are found at the ground level; and crown fires or aerial fuels burn in the tops of trees and are especially difficult to control (National Park Service, 2014 and United States Department of Interior 2010). The US Department of the Interior (2010) also discusses ladder fuels, which 
"provide vertical continuity between ground and aerial fuels, thereby allowing fire to carry from surface fuels into the crowns of trees or shrubs with relative ease" (p.24). As Blonski et al. (2010) explains, fires can be transferred through mechanisms of convection, radiation, or embers. Convection is defined as "transfer of heat by the movement of gas or liquid; convection, conduction, and radiation are the principal means of energy transfer" (Blonski et al., 2010, p. 357). Radiation is defined as "propagation of energy in free space by virtue of joint, undulatory variations in the electric or magnetic fields in space" (Blonski et al., 2010, p. 365). Radiation causes materials to ignite through proximity, and can occur from distances of 100 feet or more. The last transfer mechanism occurs when embers separate from the fire, are carried by winds, and ignite new fires through convection or radiation (Blonski et al., 2010).

\section{Fire Management Strategies and Tactics}

There are multiple fire management strategies and tactics available for wildfire prevention and preparedness, such as providing adequate staffing and resources, fuel or vegetation management, and requiring homeowners to have "defensible space," which is an area on a parcel or in a community where vegetation is modified to reduce wildfire threat. This section examines current literature on wildfire preparedness programs, 
vegetation management techniques, and case studies of guidelines and examples of other vegetation management plans.

Reams et al. (2003) surveyed administrators of wildfire risk reduction programs from 25 states about their programs. The responses from the surveys provided new insights about the efforts, goals, objectives, and obstacles that the managers of the programs are facing.

The objectives of the research by Reams et al., (2003) were to report on the current programs, specifically the perceived obstacles, as well as to examine trends in proactive management strategies. The major obstacles facing program managers in wildfire risk reduction were found to be "budget limitations, public apathy, shortages of technical staff, and resistance by property owners to removal of dangerous fuel buildup and ongoing vegetation management" (Reams et al., 2003, p. 823). Two trends in proactive management strategies, were found to be of particular importance: collaborative pre-fire planning and regular program evaluations. A majority of the respondents participated in collaborative planning, with the number of partners ranging from 1-22, with the main goal being "more effective plans" (Reams et al., 2003, p. 823). The research found that program evaluations were conducted for various reasons, and that the managers evaluated progress based upon various measurements. Some examples of performance indicators were the number of workshops or educational programs conducted in a certain 
period of time or how many properties reduced their hazardous fuel (Reams et al., 2003).

Another planning strategy that could potentially be useful in the process is Adaptive Management. Adaptive management can be described as a "systematic process for continually improving management policies and practices by learning from the outcomes of operational programs" (Senecah, 2004, p. 21). This method of planning could be useful in vegetation management, particularly due to the multiple factors that contribute to the decision making and the fact that there is not yet a clear guide on exactly what should be done and where. As Balint, Stewart, Desai \& Walters (2011) comment, "the logic of applying adaptive management to address uncertainty is compelling" and "under conditions of uncertainty, risks from adaptive management may be lower than risks from conventional approaches" (p. 99). This method may work well in the implementation and review phase of the vegetation management plan.

There are many vegetation management techniques available, each with its own advantages and disadvantages, cost, limitations, and purpose. Vegetation management techniques are determined through site specific evaluation depending on factors such as resources available, topography, vegetation, or location.

In the "Fuel Management" chapter of California's I-Zone: UrbanWildland Fire Prevention \& Mitigation, Franklin (1996) lists some useful definitions pertinent to vegetation management: 
- Fire line - narrow line, 2' to 10' wide, from which all vegetation is removed;

- Fire break - specifically, a fire line wider than 10 feet, prepared each year;

- Fire lane - an access line, prepared either ahead of the fire or in advance of the fire season forming the basis for a fire break;

- Fire control line - the mineral soil line used for firing out an area;

- Fuel break - a strategically located wide block, or strip on which a cover of heavy dense vegetation has been changed to lower fuel volume;

- Fuel break system - a system of relatively large open areas, interconnected by fuel breaks;

- Fuel modification practice - the broad approach to fuel management on a large area of wildland;

- Fuel modification treatment - an individual treatment or technique used to modify fuels. (p. 187-188)

The following paragraphs paraphrase sections from Managing Fire in the

Wildland Interface by Blonski, Miller, \& Rice (2010), in which several vegetation management techniques are explained, including average costs, limitations, and advantages and disadvantages:

\section{Manual/Hand labor}

Skilled laborers prune, cut, or remove weeds or shrubs by hand or manual tools, such as a weed whip, "weed wrench," or chain saws, for example. This method is slow, yet selective, and is useful for small-scale sites. It is best used in spot applications and areas with sensitive environmental concerns. The timing can be staggered throughout the growing season, and some limiting factors such as poison oak or availability of labor should be taken into consideration. Some advantages are: it can be selective; it is possible to execute in most conditions; it is quiet; and there is the least amount of soil disturbance. Some disadvantages are that this method is expensive, slow, short term, and can be difficult to schedule. The cost can vary from $\$ 10,000$ to $\$ 1,500$ per acre, depending on the timing, size of the project, and level of specificity required. 


\section{Tree removal}

Tree removal can vary from individual trees to removal of an entire overstory. This process can be selective with limited impacts, and also generates considerable debris that should be removed or sold commercially. Some limiting factors to consider are the social and political acceptance of tree removal, the topography of the area, and slope stability. Advantages of tree removal include:

selectiveness, reducing of spotting potential, cost effectiveness, and potential commercial value. Disadvantages of tree removal are: expense, follow-up treatment and removal of debris, potentially restricting physical conditions, and erosion potential. Lastly, the cost can be approximately $\$ 3,000-5,000$ per acre.

\section{Mechanical}

Mechanical treatments, such as grading, chipping, mowing, involve the "removal of weeds, shrubs, and small trees with use of tractor or other machinery" (p. 343). This method is ideal for larger areas or for fuel breaks and is often used with other techniques and are maintained annually. Cost is about $\$ 500$ per day with a contracted service and can modify one-half acre an hour. Some limitations are that mechanical treatments cannot be used on slopes over $30 \%$, the machines can be hard to maneuver or be selective, the equipment can weigh up to 20 tons and cannot be used on unstable soils, and there is a concern for the distribution of exotic species. Advantages of mechanical treatments: some species may benefit from mowing, this process can be efficient in larger flat areas, it can be effective in poison oak, there are minimal health concerns, it is a relatively fast process, and it can be an appropriate roadside treatment. Some disadvantages are: grading can shift natural soil profiles, mowing or disking may disturb ground nesting birds or burrowing animals, there is a required scheduling and supervising process, the effects are generally short term machinery is not suitable for steep terrain, and there are considerable maintenance, noise, and access issues associated with the equipment.

\section{Prescribed Burning}

Prescribed burning is "reintroducing fire into the ecosystem," which reduces overall volume, increases moisture of remaining fuel by removing dead and dry material, reduces fuel bed height, and changes structure through vertical and horizontal separation ( $p$. 345). There are a number of steps that need to be taken before a prescribed burn can be performed, such as coordinating with regulating agencies, obtaining approval and permits, and notifying the surrounding community and public agencies. Prescribed burning is most effective in certain vegetation such as grasslands, 
Eucalyptus groves, or oak woodland, and timing is critical due to weather constrictions. It is the "fasted, most thorough, and can be the least expensive method of removing fuel from an area" (p.345). Some advantages addressed are: that it is cost effective, it supports plants that have adapted to fire, it promotes new growth, it creates a natural-appearing boundary, it can be relatively quiet with minimal soil disturbance, it is effective in steep terrain or overstory, and it can release nutrients. Potential disadvantages of prescribed burning are: prescribed burning can be politically or socially unpopular, there is a minimum size of five acres, there is a risk of escaped fire, it requires extensive preparation, expertise, scheduling, equipment, coordination, and supervision, there are health considerations from smoke and poison oak, and there are short term visual impacts.

\section{Grazing}

Grazing is the "intentional use of animals to consume vegetation, thus reducing the amount or density of fuel," is usually done through private contract or lease arrangements, and it can occur approximately once every three years or two successive years out of six (p. 346). Grazing is ideal for grass or shrub areas, and the costs can vary from $\$ 300$ to $\$ 1,000$ per acre. Some things to consider would be the foraging preferences of the animals, fencing, water sources, predators, availability of livestock, protection of certain plant species, and public safety. Some advantages are: it is a historical land use, minimal health concerns are involved, it is quiet, can be used in areas with overstory, there is potential for revenue, and it is an excellent tool for grasslands. Disadvantages of grazing are: availability of livestock, environmental concerns for soil erosion, sensitive species, and water quality, livestock do not necessarily eat all undesirable plants, there is sometimes a strong odor associated, it requires a specialized management, and there can be some visual impacts.

\section{Chemical Treatment}

Vegetation can be killed or reduced through chemical treatment in limited areas, however, public health and environmental concerns have limited the use of these treatments. Some techniques include: chemicals that prevent germination of seeds and kill sprouted plants for firebreaks and roadside treatments; Roundup and Garlon 4-a for eradication of eucalyptus re-sprouting; Foliar application with Roundup of French Broom and Eucalyptus re-sprouts; and roadside spraying in areas of high ignition risk. Although it can be fairly inexpensive, the repetition required makes this process costly. Additionally, other limiting factors include: environmental sensitivity; timing; and effectiveness. Advantages of chemical treatment: the 
process is selective if done by hand; can be done in most physical conditions, such as wet ground and steep slopes; it is relatively quiet and quick; and there are minimal soil or erosion impacts. Some disadvantages: environmental and political sensitivity; expense; it requires follow up treatment; there are potential health hazards to the applicator, residents, and visitors; environmental damage to plants, wildlife, soil, water; timing; and government requirements. (pp. 339-349)

\section{Case Studies}

The following plans and guidelines provide a basic understanding of the structure and process of creating a Vegetation Management Plan. First is the "Town of Hillsborough Vegetation Management Strategy \& Guidelines," which offers recommendations for strategies and prioritization of projects. Second is the "Ventura Vegetation Management Plan," which provides a structure for document development. Another plan is the US Department of the Interior "Wildland Fire Management Guidelines." Lastly, the United States Forest Service "Vegetation Management Planning Guide" is a comprehensive step-by-step planning guide.

The "Town of Hillsborough Vegetation Management Strategy \& Guidelines," written by May and Associates, Inc., (2008) has two goals which are relevant to San Luis Obispo's Plan: 1) "protect natural resources;" and 2) "reduce fuel load, improve fire protection, [and] maintain forest health" (p.24). The plan states that "successful fuel management includes strategic planning and implementation of treatments ranging in scale from site-specific to landscape level" (May and 
Associates, Inc., 2008, p.30). There are a number of methods addressed in this document, including fuel and fire breaks, fire resistant landscaping, and grazing. A firebreak is explained as eliminating "all vegetation and combustible growth within a defined corridor (often a fire road) to prevent fires from spreading" (p. 34). The fuel reduction area "reduces the fuel mass and structure of flammable vegetation and combustible growth, thereby limiting the intensity of fire and slowing its rate of spread" (p.34). Another strategy is creating a shaded fuel break, which is "reducing density of underbrush," which reduces the fuel load, while still maintaining the natural habitat (p. 35). These can be achieved through mechanical methods such as mowing, thinning, or chipping. The guidelines also point out that this type of management can also lead to negative environmental impacts, such as the disruption of wildlife corridors or interference with nesting season, and therefore these strategies should be limited to the least ecologically sensitive areas and only permitted in certain seasons, to protect plant and wildlife species.

The guidelines state that "there is no ideal method" to select and prioritize projects, however, these guidelines use a system based upon the National Park Service as a potential example (May and Associates, Inc., 2008, p. 64). The suggested procedure involves a number of steps, including: creating a panel of stakeholders and experts; visually synthesizing data; identifying selection criteria; assessing capacity, 
capability and timeframe; gathering technical data; preparing project priorities; and finalizing a list of projects (May and Associates, Inc., 2008).

The "Ventura Vegetation Management Plan," written by Bob Roper (2005), was used for the City of San Luis Obispo Open Space Vegetation Management Plan as a guideline based upon professional recommendations as well as similarity of location and vegetation. The structure of the document consists of an "Executive Summary," a "Description of the County and the Fire Protection District," a "General Description of the Current Fire Situation," and individual "Project Descriptions" (Roper, 2005, p. 2).

The "Wildland Fire Management Guidelines," written by the United States Department of the Interior (2010), is a handbook that is intended for use as a resource for development of fire management programs. Due to areas varying in features such as topography and vegetation, "creativity and flexibility are encouraged" in this guide (US Department of the Interior, 2010, p. 1). This document addresses plan development, agreements, prescribed fires, fuels management, fire prevention and education, and definitions and acronyms. A useful section of these guidelines discusses different components of fuels and the "Time-lag Concept," which is explained as:

"The more moisture a given piece of fuel holds, the longer it takes to reach a given temperature and the longer it will take to burn. Fuels gain and lose moisture constantly depending on conditions. In the case of live plants this moisture content is a result of plant morphology and how much moisture the plant has available to it from the soil. In the case of dead fuels, moisture content is gained 
or lost from exposure to the ambient moisture content of the atmosphere. In dead fuels, the relationship between size, moisture content, and fire behavior is known as the time-lag concept" (p. 22)

Another concept addressed is the "live fuel moisture" which is for living fuels and depends on the season, plant, weather, and soil conditions. Live and dead fuel moisture generally gets measured on a regular basis, as this can control fire intensity and is important for fire prediction models.

These guidelines also discuss fire prevention and education, specifically efforts that can be taken to increase awareness of prescribed burning. These guidelines recommend holding public meetings, creating educational brochures, and having other methods of outreach pertaining to prescribed burning efforts.

The template this document provides for a management plan includes:

- Introduction

- Relationship to Land Management Planning/Fire Policy

- Wildfire Fire Management Strategies

o General Management Considerations

o Wildland Fire Management Goals

- Wildland Fire Management Options

o Description of Strategies

- Wildland Fire Management Program Components

o Wildland Fire Suppression Actions

o Wildland Fire Use

o Prescribed Fire

o Non-Fire Fuel Applications

o Emergency Rehabilitation and restoration

- Organization and Budget

- Monitoring and Evaluation

- Glossary

- Appendix (US Department of the Interior, 2010, p. 42) 
This template was utilized as a resource for creating the Management Plan for San Luis Obispo.

The "Vegetation Management Planning Guide: Planning and Implementation for Developed Sites in Region 2" by the United States Forest Service (2002) is meant to be used for wildland urban interfaces in National Forest System lands, yet some of the guidelines can be applied to San Luis Obispo. The goal of the guidelines is to have comprehensive planning, and the guidelines point out that "to meet goals requires careful thought, an interdisciplinary approach to planning and implementation, and a long-term vision" (United States Forest Service [USFS], 2002, p.7). The guide recommends a seven step process for developing a vegetation management plan:

1. Compile and assess data that includes:

a. Physical site conditions

b. Vegetation assessment

c. Disease and insect site visits

d. Hazard tree surveys

e. Fuels and defensible space

f. History of vegetation management

g. Physical improvements and uses

2. Describe desired future conditions

3. Compare existing conditions to desired future conditions

4. Identify alternative methods to achieve future conditions

5. Select an alternative and outline actions

6. Implement actions

7. Monitor actions. (USFS, 2002, p.9)

For each step of the process, the guide explains strategies to gather information, such as conducting an inventory of vegetation including "dominant tree species," "understory species," and other 
"general observations" (USFS, 2002, p. 10). This guide also addresses

how to make a "communication plan" for the preferred project actions. The communication plan should consider: "interpretation (signs, pamphlets, newspaper articles, campfire talks); scoping (newspaper articles, letters); coordination with other agencies, utility companies, local landowners, and/or the concessionaire; prevention of future vegetation damage through education; how the public might help through partnerships and volunteer efforts; [and] the best way to communicate with those who will be affected" (USFS, 2002, p. 15).

\section{Related Documents}

The adopted policy documents in the section are relevant to wildfire planning in San Luis Obispo. In addition, each of these documents required a considerable amount of public input and feedback in their development.

\section{San Luis Obispo General Plan}

The General Plan for the City of San Luis Obispo was last updated in 2007 and is the governing document to guide development and land uses in the city, with goals, policies, and programs that are to be implemented. San Luis Obispo's General Plan contains a number of elements: Land 
Use, Circulation, Housing, Noise, Safety, Conservation and Open Space, Parks and Recreation, and Water and Wastewater. The most relevant elements that address wildfire planning in San Luis Obispo are Conservation and Open Space, and Safety.

In the Safety Element, the policies related to fire are primarily concerning development standards for fire-resistant materials in buildings and having adequate services for fire prevention and response. San Luis Obispo is also described as an area that has been shaped by fire, and the plan states that "where the burning of natural vegetation is a threat to people's lives and property, plant fuels are often managed by replacement planting, grazing, plowing, or mechanical clearing" (City of San Luis Obispo [City of SLO], 2007, p. 5-9). The plan also addresses the areas with highest wildfire hazard potential: "the Irish Hills, Santa Lucia foothills, Cerro San Luis Obispo, Bishop Peak, and Islay Hill;" additionally, "fire hazards in wildlands are often compounded by their distance from firefighting resources" (City of SLO, 2007, p.5-9). This could pose an issue for Open Space areas that are located farther away from firefighting resources, which is one of the reasons why the City also relies on mutual aid agreements.

In September, 2012, Senate Bill No. 1241 amends the Safety Element. It states:

This bill would revise the safety element requirements for state responsibility areas and very high fire hazard severity zones, as specified, and require the safety element, upon the next revision of the housing element on or after January 1, 2014, to be reviewed 
and updated as necessary to address the risk of fire in state responsibility areas and very high fire hazard severity zones, taking into account specified considerations, including, among others, the most recent version of the Office of Planning and Research's "Fire Hazard Planning" document. The bill would also require the office to, at the next update of its general plan guidelines, include these provisions, or a reference to these provisions and any other materials related to fire hazards or fire safety it deems appropriate. By imposing new duties on a city or county with regard to reviewing and updating its general plan, the bill would impose a statemandated local program. (California Legislative Information, 2012, para. 2)

The Conservation and Open Space Element has a few policies and programs that address wildland fires, which are as follows:

8.5.4 Fire prevention activities. Except in an emergency, fire prevention activities such as fuel clearance or thinning, grading, prescribed burns or other activities shall be conducted pursuant to an approved Conservation Plan, and under the supervision of the Natural Resources Manager and Fire Marshall. Habitat preservation shall be given equal priority with fire prevention. (City of SLO, 2007, p. 6-52)

This is necessary to keep in mind when planning, especially when considering the number of factors that contribute to decision making about fire prevention, specifically habitat and wildlife preservation. The other policy in the Conservation and Open Space Element related to wildfire prevention is:

8.7.2 Enhance and restore open space. The City will do the following in support of open space enhancement and restoration, in coordination with other agencies and organizations, and will encourage individuals, organizations, and other agencies to take the same actions within their areas of responsibility: ... J. Following adequate public review, adopt conservation plans for open space areas under City easement or fee ownership. The plans shall include a resource inventory, needs analysis, acceptable levels of change, grazing, monitoring, and wildlife (including listed species, sensitive species, and species of local concern) management and 
implementation strategies, including wildfire preparedness plans. (City of SLO, 2007, p. 6-56-57)

The Conservation Guidelines are addressed in the next section.

\section{Conservation Guidelines for Open Space Lands, City of San Luis Obispo}

The Conservation Guidelines document consists of background information and policies intended to guide the preparation of Conservation Plans that will be/are prepared for each Open Space property in San Luis Obispo.

Policy 4.1 titled "Land and Vegetation Management" states that "the City will monitor and manage vegetation to meet prescribed goals for the land (LV10). Management strategies such as the use of selective livestock grazing (LV1); physical pruning/removal of unwanted or problematic vegetation (LV6); erosion and sediment control (LV7); application of Integrated Pest Management practices (LV12; LV13); and prescribed burning of native vegetative communities (LV8), will be implemented where necessary" (City of San Luis Obispo Administration Department, 2002, p.12). These management strategies have been arranged in an appendix in the original document (LV is "Land and Vegetation"), and are used in preparing Conservation Plans for individual Open Spaces.

Livestock grazing may be permitted as determined by the Natural Resources Program with public input, and will only be allowed during 
"specific times of the year when the risk of damage to the resource is minimal, and grazing privileges may be revoked at any time at the City's discretion" (City of San Luis Obispo Administration Department, 2002, p.12-13).

Furthermore, the City is required to create individual Wildfire Preparedness Plans in collaboration with CAL FIRE, which will be included in each respective Open Space's Conservation Plan. Vegetation should be continuously monitored, and "the plan will identify appropriate firefighting methods for use in City open spaces that have minimal impact on the natural resources represented on the site, providing the use of such methods does not put property or human life at risk (LV9) (City of San Luis Obispo Administration Department, 2002, p.13).

\section{Conservation Plans, City of San Luis Obispo}

The City of San Luis Obispo is in the process of developing a Conservation Plan for each Open Space. Currently, there are Conservation Plans for the following Open Spaces:

- Bishop Peak Natural Reserve

- Cerro San Luis Conservation Plan

- Irish Hills Conservation Plan

- Johnson Ranch Conservation Plan

- South Hills Conservation Plan

- Stenner Springs Natural Reserve Draft Conservation Plan 
- Reservoir Canyon Natural Reserve Conservation Plan (Draft)

The Conservation Plans are also required to include Wildfire Preparedness Plans for each Open Space Parcel. Each of the Conservation Plans goes through a public input period in its development process. Content from the Conservation Plans provides a basis of background information for the Vegetation Management Plan.

\section{Local Hazard Mitigation Plan, City of San Luis Obispo}

The Local Hazard Mitigation Plan (LHMP) addresses potential hazards in San Luis Obispo such as floods, earthquakes, tsunamis, and wildfires, and policies and programs to reduce impacts of these hazards. San Luis Obispo's City Council approved the most recent update of the LHMP in March of 2014, and as of June 2014 it is in the review process with California Office of Emergency Services (Cal OES) and will then await approval from FEMA.

Responses to a survey released during plan development found that respondents' "Level of Concern" for wildfires was 2.01 on a scale of 03, with 3 being of highest concern (City of San Luis Obispo [City of SLO], 2014 , p. 12). Wildfires were second to earthquakes, which had a score of 2.27. Additionally, in the Risk Assessment and Prioritization section, data was analyzed for each hazard based on Probability, Impacts (affected area, primary and secondary impacts), and Level of Concern. The total 
scores were then determined, with Wildland Fires being ranked second in priority, after Earthquakes/Liquefactions (City of SLO, 2014, p. 21).

The City LHMP (2014) states that San Luis Obispo is considered a "Community at Risk" and "is confronted with one of the more hazardous wildfire risks in the County because of its location near the foothills of the Santa Lucia Mountains and the Irish Hills, with increased wildfire risk in these foothills as well as on Chumash Peak, Bishop Peak, Cerro San Luis, and Islay Hill" (p. 40). There are a few actions written in the document for wildfire mitigation. The first is Action Number: 2.A.10, which states to "enhance partnerships with CAL Fire and the local Fire Safe Council for fuel reduction efforts" and is a new proposed hazard mitigation action that wasn't on the last LHMP. (City of SLO, 2014, p.113). The California Fire Safe Council is a non-profit organization that serves as a grants clearinghouse for wildfire prevention. Another proposed high priority action, Number 2.A.8, is to "continue to conduct current fuel management programs and investigate and apply new and emerging fuel management techniques" in coordination with the Fire Department, Natural Resources Director, Parks and Recreation. The potential funding sources proposed are FEMA and Fire Safe Council grants. This action could "reduce the potential for wildland fires by improving and expanding the current fuel management program." (City of SLO, 2014, p. 117). 


\section{Local Hazard Mitigation Plan, County of San Luis Obispo}

The County LHMP was approved in December 2013 by the County Board of Supervisors and the Flood Control and Water Conservation District, and as of June 2014 it is still being reviewed by Cal OES and FEMA. The LHMP for the county addresses similar issues to the City LHMP.

The 2011 County LHMP is the prior adopted document which was approved by FEMA and Cal OES. This LHMP states that the risk of wildfire in San Luis Obispo County is ranked "High" to "Very High," due to "the fuels, topography, and weather conditions of the county" (San Luis Obispo County [SLO County], 2011, p.114). The County LHMP considers the City of San Luis Obispo a wildland/urban interface area; therefore, there is a Fire Prevention Code which has been adopted by the City which has requirements for hazardous fire areas such as fire-resistant roofing materials (SLO County, 2011, p. 114). Goal 5 in the LHMP is related to wildland fires, which states: "Minimize the level of damage and losses to people, existing and future critical facilities and infrastructure due to wildland fires" (SLO County, 2011, p. 172). The objectives and mitigation actions related to this goal are as follows:

Objective 5.1: Develop a comprehensive approach to reducing the level of damage and losses due to wildland fires through vegetation management, weed abatement, code enforcement, GIS mapping, and planning processes ...

Mitigation Action 5.B: In order to assist fire prevention efforts and to better manage large fire when the occur, continue to improve GIS mapping and tracking efforts by gathering and maintaining relevant GIS data layers and imagery and utilizing the best available mapping applications and software. 
Mitigation Action 5.C: Work with the San Luis Obispo County Fire Safe Council to initiate fuel thinning and chipping projects in high priority areas. Collaborate with property owner and regulatory agencies in order to utilize prescribed fire on private and state owned lands in the county.

Mitigation Action 5.D: Create and maintain fuel breaks in strategic locations.

Mitigation Action 5.E: Utilizing grant funding, develop a Community Wildfire Protection Plan for the County that will: Assess the fire hazard in the county; Prioritize treatment areas; Enhance collaboration among all fire agencies and stakeholders; and streamline environmental review process. (SLO County, 2011, p. 172-173)

The 2011 LHMP for the County helps to guide mitigation policies for each city in its jurisdiction, including San Luis Obispo.

The most recent (2013) version of the County LHMP identifies hazards and ranks them based upon probability, impacts, and public concern based on a survey. Using this system, wildfire in the county is considered "Significant," on a ranking of "limited - moderate - significant," scoring a 57.20 out of 74 (San Luis Obispo County, 2013 p.36).

\section{Community Wildfire Protection Plan, County of San Luis Obispo} The Community Wildfire Protection Plan (CWPP) for the County of San Luis Obispo (2013) was developed collaboratively by interested parties and stakeholders, such as representatives from CAL FIRE SLO, Fire Chiefs from all involved Cities, representatives from the Bureau of Land Management, and the San Luis Obispo County Community Fire Safe 
Council. The CWPP is a "planning and assessment tool" which "identifies and prioritizes pre fire and post fire management strategies and tactics meant to reduce the loss of values at risk within the County" (p. iv). This plan acts as a "key component of the Healthy Forest Restoration Act (HFRA) of 2003," and "serves as a mechanism for community input and identification of areas presenting high fire hazard risk as well as identification of fire hazards potential projects intended to mitigate such risk" (p.1). The contents of the CWPP include: a County Overview, such as population and housing, vegetation, weather, and fire history; different communities and agencies that participated in the collaboration process; Values at Risk, including assets and priority communities; pre-fire management strategies and tactics; and plan recommendations and management. 


\section{Discussion of Lessons Learned and Recommendations}

I believe that the process and methodology utilized in the plan development was effective. I enhanced my GIS skills and learned a significant amount about different wildfire management techniques and how to determine the best practices in the field. I also gained a particular interest in the balance between natural resources management and wildfire protection, as well as a better understanding of the planning process and collaboration involved in producing these plans.

Some recommendations I have for the future are to maintain interagency collaboration, which the City already does well. Additionally, I recommend that Fire Modeling be done for each of the Open Spaces in order to further understand the potential fire behavior. I also suggest that there be continuous outreach and education to local communities, particularly those adjacent to open space properties at high risk. The City should update the Vegetation Management Plan as necessary, and reflect and evaluate effectiveness of the projects that are implemented, subsequently revising procedures as best seen fit. Lastly, I recommend that the City complete the Conservation Plans for Terrace Hill and Laguna Lake Open Spaces. 


\section{References}

Balint, P. J., Stewart, R. E., Desai, A., \& Walters, L. C. (2011). Adaptive management. In Wicked environmental problems: Managing uncertainty and conflict (pp. 79-102). Retrieved from http://link.springer.com/chapter/10.5822/978-1-61091-047-7_5

Blonski, K., Miller, C., \& Rice, C. L. (2010). Managing fire in the wildland interface. Point Arena, California: Solano Press Books.

Busenberg, G. (2004). Wildfire management in the United States: The evolution of a policy failure. Review of Policy Research, 21(2), 145156. doi: 10.1111/j.1541-1338.2004.00066.x

California Fire Safe Council. (2013). Fire prevention grant terms glossary. Retrieved on March 15, 2014, from http://www.cafiresafecouncil.org/fire-prevention-grant-termsglossaryl

California Legislative Information. (2012, September 13). Senate Bill No. 1241. Retrieved on June 12, 2014, from website: http://leginfo.legislature.ca.gov/faces/billHistoryClient.xhtml

CAL FIRE/San Luis Obispo County Fire, (2013).Community wildfire protection plan (draft). Retrieved from website: http://www.calfireslo.org/CWPP.html

City of San Luis Obispo. (2014). City of San Luis Obispo draft local hazard mitigation plan. Retrieved from website:

http://slocity.org/cityclerk/agendas/2014/020414/ph4localhazardmiti gationplan.pdf

City of San Luis Obispo Administration Department, Natural Resources Program. (2002). Conservation guidelines for open space lands of the city of San Luis Obispo. Retrieved from City of San Luis Obispo website:

http://www.slocity.org/naturalresources/download/SLO_opnspcWE B.pdf

City of San Luis Obispo, Community Development Department. (2007). City of San Luis Obispo general plan. Retrieved from website: http://www.slocity.org/communitydevelopment/Long Range/generalplan.asp 
Federal Emergency Management Agency. (2001). State and local mitigation planning how-to guide: Understanding your risks identifying hazards and estimating losses (FEMA 386-2). Retrieved from FEMA website:

http://www.fema.gov/library/viewRecord.do?id=1880

Federal Emergency Management Agency. (2002). Federal Emergency Management Agency resource record details: Disaster mitigation act of 2000. Retrieved on March 15, 2014, from http://www.fema.gov/library/viewRecord.do?id=1935

Federal Emergency Management Agency, Emergency Management Institute. (2011 a). Fundamentals of emergency management: Independent study 230.b. Retrieved on March 15, 2014, from http://training.fema.gov/EMIWeb/IS/IS230B/IS230bCourse.pdf

Federal Emergency Management Agency. Federal Emergency Management Agency fact sheet: State and local mitigation planning. (2011 b). Retrieved from http://www.fema.gov/pdf/media/factsheets/2011/mit_state_local_pla n.pdf

Federal Emergency Management Agency. (2012 a). Federal Emergency Management Agency: About the agency. Retrieved on March 15, 2014, from http://www.fema.gov/about

Federal Emergency Management Agency. (2012 b). Federal Emergency Management Agency: Mitigation planning. Retrieved on March 15, 2014, from http://www.fema.gov/library/viewRecord.do?id=2066

Federal Emergency Management Agency. (2013, September 26). Disaster mitigation act of 2000. Retrieved on March 15, from http://www.fema.gov/medialibrary/assets/documents/4596?id=1935

Franklin, S. E. (1996). Fuel management. In R. Slaughter (Ed.), California's I-Zone: Urban-wildland fire prevention \& mitigation: Instructors guide (pp. 184-193). PreFire Engineering Division.

Fried, J. S., Torn, M. S., \& Mills, E. (2004). The impact of climate change on wildfire severity: A regional forecast for northern California. Climate Change, 64, 169-191. Retrieved from http://evanmills.lbl.gov/pubs/pdf/wildfire_and_climate_change.pdf 
Kenward, A., \& Raja, U. (2013, August 28). Nearly Half of All Western Wildfire Costs Go To California | Climate Central. Retrieved June 13, 2014, from http://www.climatecentral.org/news/nearly-half-of-allwildfire-costs-go-to-california-16406

May and Associates, Inc. Town of Hillsborough, Public Works. (2008). Town of Hillsborough vegetation management strategy \& guidelines (including project selection for open space lands). Retrieved from May and Associates, Inc. website: http://www.hillsborough.net/civica/filebank/blobdload.asp?BlobID=4 838

National Park Service, US Department of the Interior (2014). Fire and aviation management: Fire spread. Retrieved on April 1, 2014, from http://www.nps.gov/fire/wildland-fire/learning-center/fire-indepth/fire-spread.cfm

Pearce, L. (2003). Disaster management and community planning, and public participation: how to achieve sustainable hazard mitigation. Natural hazards, 28, 211-228. Retrieved from http://link.springer.com/article/10.1023/A:1022917721797

Reams, M. A., Haines, T. K., Renner, C. R., Wascom, M. W., \& Kingre, H. (2005). Goals, obstacles and effective strategies of wildfire mitigation programs in the wildland-urban interface. Forest Policy and Economics, 7, 818-826. Retrieved from http://www.sciencedirect.com/science/article/pii/S13899341050004 $7 \mathrm{X}$

Roach, J. (2014, April 12). "'That was home:' Residents rebuild in wildfire prone areas." NBC News. Retrieved on April 15, 2014, from http://www.nbcnews.com/science/environment/was-homeresidents-rebuild-wildfire-prone-areas-n75871

Roper, B. County of Ventura, Fire Department. (2005). Ventura County fire protection district fire management plan. Retrieved from website: http://fire.countyofventura.org/LinkClick.aspx?fileticket=hlthDPzu3z $\mathrm{c}=\&$ tabid $=56$

San Luis Obispo County, Office of Emergency Services. (2011). San Luis Obispo County local hazard mitigation plan. Retrieved from website: http://www.slocounty.ca.gov/Assets/OES/Plans/Hazard Mitigation Plan 2011.pdf

San Luis Obispo County, Office of Emergency Services. (2013). San Luis Obispo County local hazard mitigation plan public review DRAFT. 
Retrieved from website:

http://www.slocounty.ca.gov/Assets/OES/LHMP.pdf

Schwab, J., Meck, S., \& Simone, J. (2005). Planning for wildfires.

Chicago, IL: American Planning Association.

Senecah, S. L. (2004). Adaptive Management. In R. M. Stapleton (Ed.), Pollution A to Z (Vol. 1, p. 21). New York: Macmillan Reference USA. Retrieved from

http://go.galegroup.com/ps/i.do?id=GALE\%7CCX3408100014\&v=2 $.1 \& u=$ calpolyw_csu\&it=r\&p=GVRL\&sw=w\&asid=050af6e6295fdc0b cfb00cce9780963f

State of California, The Governor's Office of Planning and Research. (2003 a). State of California: General plan guidelines. Retrieved from website:

http://opr.ca.gov/docs/General_Plan_Guidelines_2003.pdf

State of California, The Governor's Office of Planning and Research, (2003 b). Fire hazard planning: General plan technical advice series. Sacramento, CA: The Governor's Office of Planning and Research.

Tullis, P. (2013, September 22). Into the wildfire: What science is learning about fire and how to live with it. The New York Times Magazine, 26-59.

U.S. Census Bureau; Census 2010, Summary File 1: Profile of General Population and Housing Characteristics, Table DP-1; generated by Danielle Althaus; using American FactFinder; $<$ http://factfinder2.census.gov/faces/tableservices/jsf/pages/product view.xhtml?pid=DEC_10_SF1_SF1DP1\&prodType=table>; (14 November 2013).

United States Department of Agriculture, Forest Service. (2002). Vegetation management planning guide: Planning and implementation for developed sites in region 2. Retrieved from website:

http://www.fs.usda.gov/Internet/FSE_DOCUMENTS/fsbdev3_0389 83.pdf

U.S. Department of the Interior, Bureau of Reclamation. (2010). Wildland fire management guidelines. Retrieved from website: http://www.usbr.gov/lands/WFM_Guidelines.pdf 
Weeks, J. (2012). Managing wildfires: Can they be controlled in a warming world?. CQ Researcher, 22(39), 941-964. Retrieved from http://library.cqpress.com/cqresearcher/document.php?id=cqresrre 2012110200\&type $=$ hitlist\&num $=0$ 
Appendix A: City of San Luis Obispo Open Space Vegetation Management Plan 


\section{CITY OF SAN LUIS OBISPO OPEN SPACE}

\section{VEGETATION MANAGEMENT PLAN}




\section{TABLE OF CONTENTS}

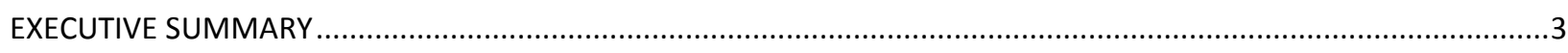

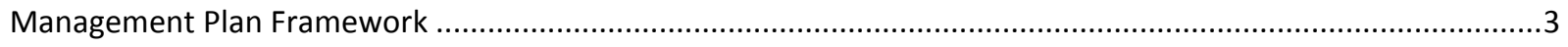

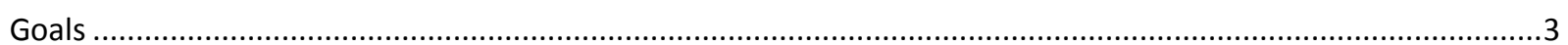

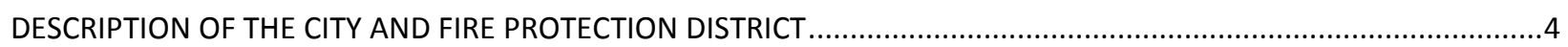

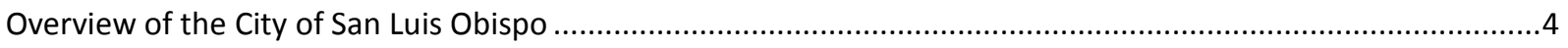

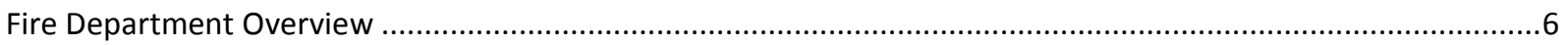

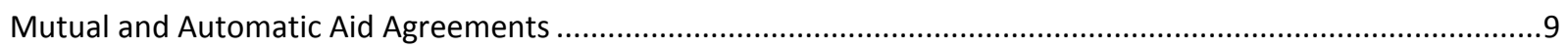

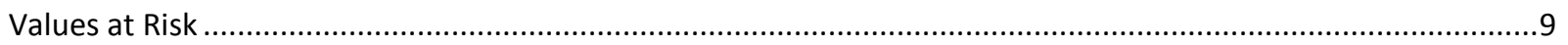

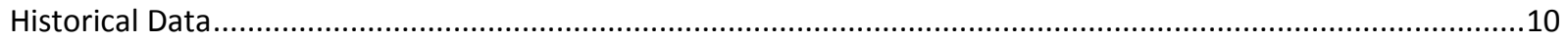

Fire Hazard Severity Zones.....................................................................................................................

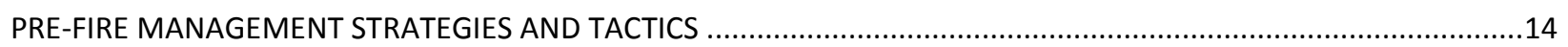

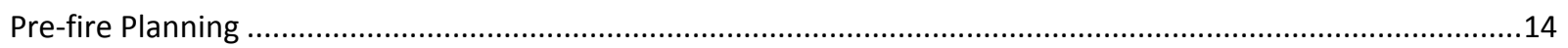

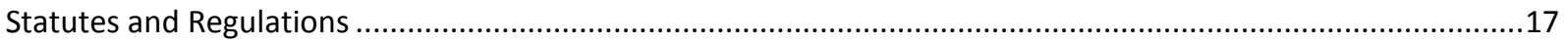

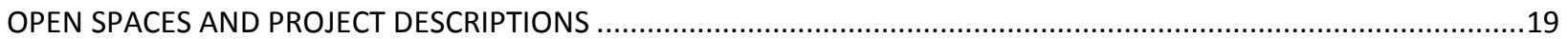

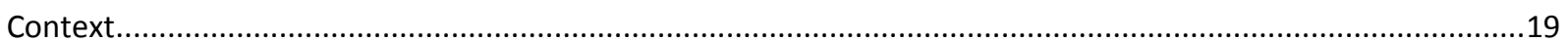

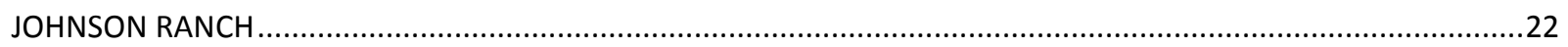

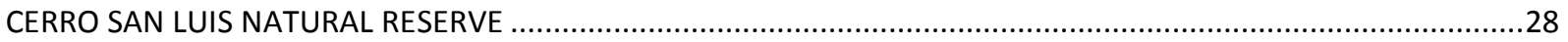

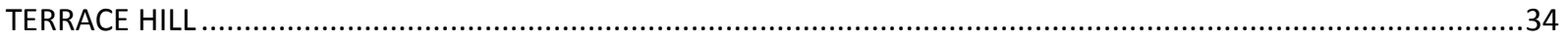

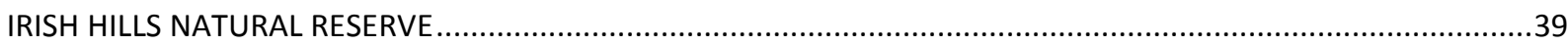

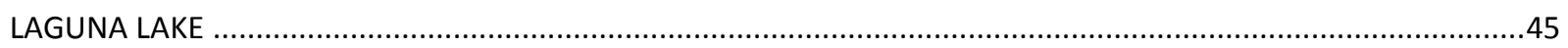

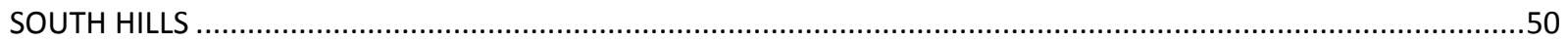

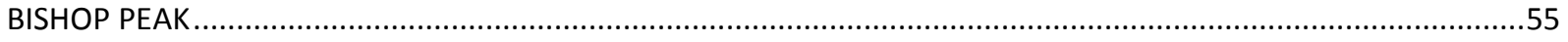

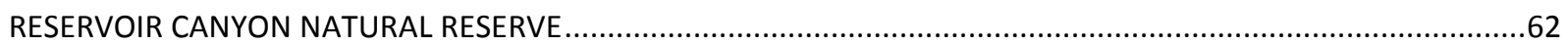

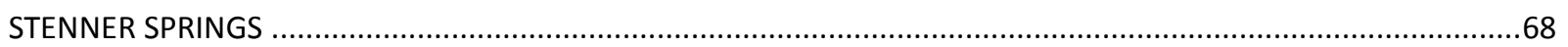

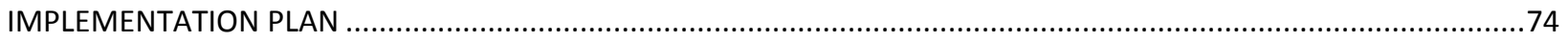

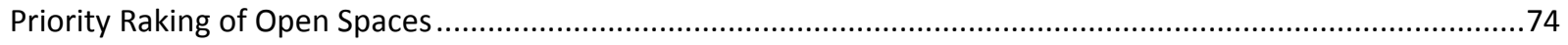

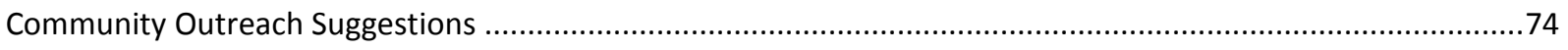

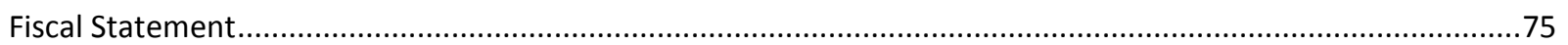

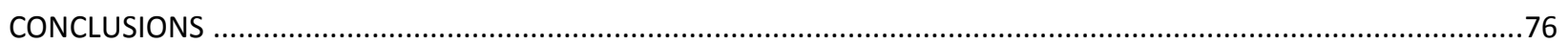

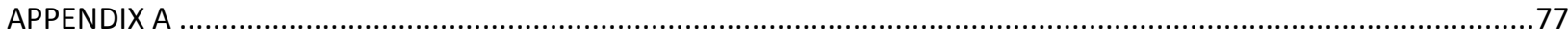

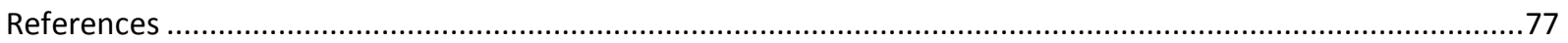

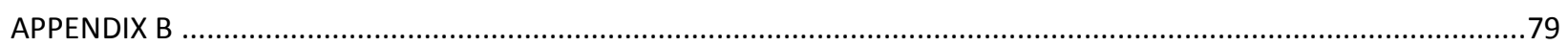

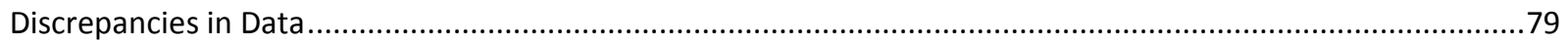


The City of San Luis Obispo is located in San Luis Obispo County on the Central Coast of California, with a population of about 45,000 people (U.S. Census Bureau, 2010 Census). There are 12 large open space lands totaling about 4,000 acres, as well as additional conservation easements, all operated by the City.

This plan is intended to be a comprehensive document which addresses how the City is managing wildfire preparedness in city-owned Open Space properties. This document could be used to organize and prioritize future pre-fire and vegetation management projects in the Open Space properties. Each Open Space property is addressed, identifying its location, vegetation, topography, assets, access points, water supply, evacuation routes, historical fire data, predominant risk exposure, current wildfire preparedness plan, as well as a priority ranking. There is also a proposed implementation plan.

\section{Management Plan Framework}

The Conservation and Open Space Element of the City of San Luis Obispo General Plan requires that each Open Space in San Luis Obispo have its own "Open Space Conservation Plan," and that each of those plans shall contain a "Wildfire Preparedness Plan." The content developed for each open space in the Management Plan will be consistent with General Plan, and be contributing to, deriving information from, and adding to the Wildfire Preparedness Plan sections in the Conservation Plans for each Open Space.

\section{Goals}

The goal of this Vegetation Management Plan is to:

- Reduce total cost and losses of life and property from wildland fire

This will be achieved through the following objectives:

- Describe all open space properties owned by the city

- Assess pre-fire management prescriptions

- Identify high-risk areas and ways to reduce hazards and risks

- Promote continuous multidisciplinary and intergovernmental collaborative efforts to reduce wildland fire risk 


\section{Overview of the City of San Luis Obispo}

The City of San Luis Obispo is located in San Luis Obispo County on the central coastal of California. It is approximately 12.8 square miles, located in a valley surrounded by the Coastal Range. The topography of San Luis Obispo is extremely hilly. Additionally, State Highways 1 and 101, San Luis Creek, Southern Pacific Railroad lines, and mountains split the community.

The City has a fire protection contract with California Polytechnic State University (Cal Poly) to provide emergency services to students and faculty, although the University itself it is not located in the city limits. There are approximately 20,000 students and faculty at the university as of 2011. Cal Poly is recognized internationally for its excellence in preparing undergraduates for careers in applied technical and professional fields. Cal Poly graduates are highly sought after to fill architecture, agriculture, business, computer science and engineering positions.

The Diablo Canyon Nuclear Power Plant, operated by Pacific Gas and Electric Company, consists of two nuclear power generating units. This plant is located on the San Luis Obispo County coast approximately 12 miles southwest of the City. Diablo Canyon has been identified as a potential terrorist target and is on the California National Guard's Critical Asset List. The City is in the Basic Emergency Planning Zone (BEPZ) established by the California Emergency Management Agency (Cal EMA) as required by the Nuclear Regulatory Commission and FEMA.

San Luis Obispo County is primarily a rural and agricultural area encompassing 3,300 square miles of land, 100 miles of coastline, and is home to over 238,000 residents. There are seven cities within the County borders, but large unincorporated areas separate most of them. The County's location and size dictates that individual fire agencies use mutual aid assistance from their neighboring agencies.

\section{Demographics}

The City of San Luis Obispo is a beautiful central coast community with a population of 44,350 . The San Luis Obispo area presents a unique combination of rural living and a sophisticated cultural environment, enhanced by the presence of Cal Poly State University. The City is the County seat and center of County activity, with a daytime population of over 75,000.

\section{Climate}

The climate is pleasant year round with summer temperatures rarely exceeding 90 degrees and it is not uncommon to have winter days in the 70s. The ideal weather provides numerous opportunities for outdoor recreation. San Luis Obispo is a destination location for tourists. 


\section{Water}

The water distribution program delivers potable water from the water treatment plant and wells to customers and fire hydrants via ten pump stations, thirteen water storage facilities, and approximately 170 miles of water mains. It is unlikely this basic distribution pattern will change, since the water treatment plant will continue to be the principal source of treated water for the City.

Growth within the City has placed increased demands on the water distribution system. Additionally, some of the pipes in the system are undersized based on current standards which reduce the fire flow capacity. The undersized pipes will be replaced over time with new 8-inch or larger mains that will improve fire flow capabilities. Even without growth or fire protection requirements, aging pipes must be replaced to avoid major service disruptions and leaks due to deterioration.

There are approximately 170 miles of water distribution pipelines throughout the City. The engineering estimate for the life expectancy of these facilities is 50 years. Complete replacement within the term of life expectancy would require that the City replace an average of $2 \%$ of the system infrastructure each year, which the City has established as the goal.

\section{Transmission System}

Parts of the City's water transmission and distribution system are over 100 years old. Most of the older pipes are made of cast iron. Other pipes are made of asbestos cement (located primarily in the Laguna Lake area), ductile iron or, since the mid-1970's, PVC. Water pipes serve two basic functions. The larger pipes or transmission mains move large volumes of water from one portion of the City to another. They range in size from 12 inches to 30 inches. The smaller pipes or distribution mains are to distribute water within a local area and deliver it to each property in the City. They range in size from 6 inches (in the older portions of the City) to 12 inches. The current minimum standard is 8 inches for distribution mains.

Treated water from the City's water treatment plant is divided into two separate pressure zones before leaving the plant site. The transfer pump station located on the water treatment plant site pumps approximately $50 \%$ of the water into the high pressure zone that provides water to Stenner Canyon Reservoir, Cal Poly, and other portions of the City, generally north and east of the Union Pacific Railroad tracks. The other portion of water flows by gravity to the lower pressure zone areas of the City.

\section{Pressure Zones}

The water delivered from the treatment plant is split into two main distribution networks. About $50 \%$ flows into the City by gravity and the other $50 \%$ is pumped to a storage reservoir at a higher elevation and then flows into the various service areas by gravity and through pressure reducing valves (PRV's). The most apparent strain is in the pumped delivery system. Since electrical power for pumping water is a major expense, a goal is to develop a system which minimizes pumping. The goal of the water supply system is to deliver water at pressures 
between 40 pounds per square inch and 80 pounds per square inch at the customer's meter without using a pressure reducing valve on the pipe connecting the water main to the meter. This pressure range will meet the needs of most irrigation sprinklers and other uses, and provide adequate pressure for fire sprinkler systems. Pressure zones are established in the distribution system to maintain these pressure ranges. The City currently has 16 pressure zones divided between the gravity and pumped delivery systems.

\section{Fire Department Overview}

San Luis Obispo City Fire Department currently protects a population of approximately 45,000 people; however that number increases to over 75,000 during the daytime hours as we are also the county seat. Our department also provides fire protection for California Poly State University (Cal Poly) which adds an additional 20,000 people to our population. We provide services for everything from EMS to structural firefighting, from wildland/WUI fires to structural collapse, and from earthquakes to explosions or terrorist activities. San Luis Obispo is the largest community neighboring the Diablo Canyon Nuclear Power Plant and provides mutual aid to the plant during emergencies.

The emergency response program protects life and property by responding to medical emergencies, fires, hazardous materials incidents, and other emergencies. Program goals are timely responses to emergency calls ( 4 minutes for fire suppression and for medical responses), no loss of life from reported emergencies and minimal property damage from reported emergencies.

\section{Fire Station One}

(2160 Santa Barbara Avenue) The newest firehouse in the city, Fire Station One at Broad and South Streets, and designed to support the Fire Department into the next century, the facility cost about $\$ 3.2$ million. It houses the administrative offices, the Fire Prevention Bureau, and the department's maintenance shop with one mechanic, as well as emergency response vehicles. The station is staffed by a Battalion Chief and a 4-person paramedic truck company. Truck 1 is a 2010 Pierce 1500 GPM Quint with a 100 foot aerial ladder. Station 1 also houses a second line 1993 Pierce 1500 GPM Quint with a 75 foot ladder, Patrol 1, a 2007 Ford F-550 4X4 Type-4 Patrol, and Squad 1, a 1998 Ford E450 Wheeled Coach Emergency Patient Transport.

\section{Fire Station Two}

(126 No. Chorro) This is the oldest station, built in 1954. The station is staffed with a 3-person paramedic engine company. Engine 2 is a 2000 Pierce Lance 1500 GPM Triple-combination pumper. Station 2 also house OES 271, a State owned 2000 KME Westates Type-2 heavy rescue engine. 


\section{Fire Station Three}

(1280 Laurel Lane) Completed in 1960 to cover growth at the south end of the city, Station 3 is located at the corner of Laurel Lane and Augusta Street. The station is staffed by a 3-person paramedic engine company. Engine 3 is a 2003 Pierce Lance 1500 GPM Triple-combination pumper. Station 3 also houses Engine 5, a 1991 Pierce Javelin 1500 GPM Triple-combination pumper (reserve).

\section{Fire Station Four}

(1395 Madonna Road) Constructed in 1978, Fire Station Number Four is located at the intersection of Madonna Road and Los Osos Valley Road. The station is staffed by a 3-person paramedic engine company. Engine 4 is a 1997 Pierce Lance 1500 GPM Triple-combination pumper. Station 4 also houses Engine 6, a 2007 Westmark Type 31000 GPM 4X4 Wildland Unit. 


\section{Open Spaces and Fire Stations in San Luis Obispo, CA}

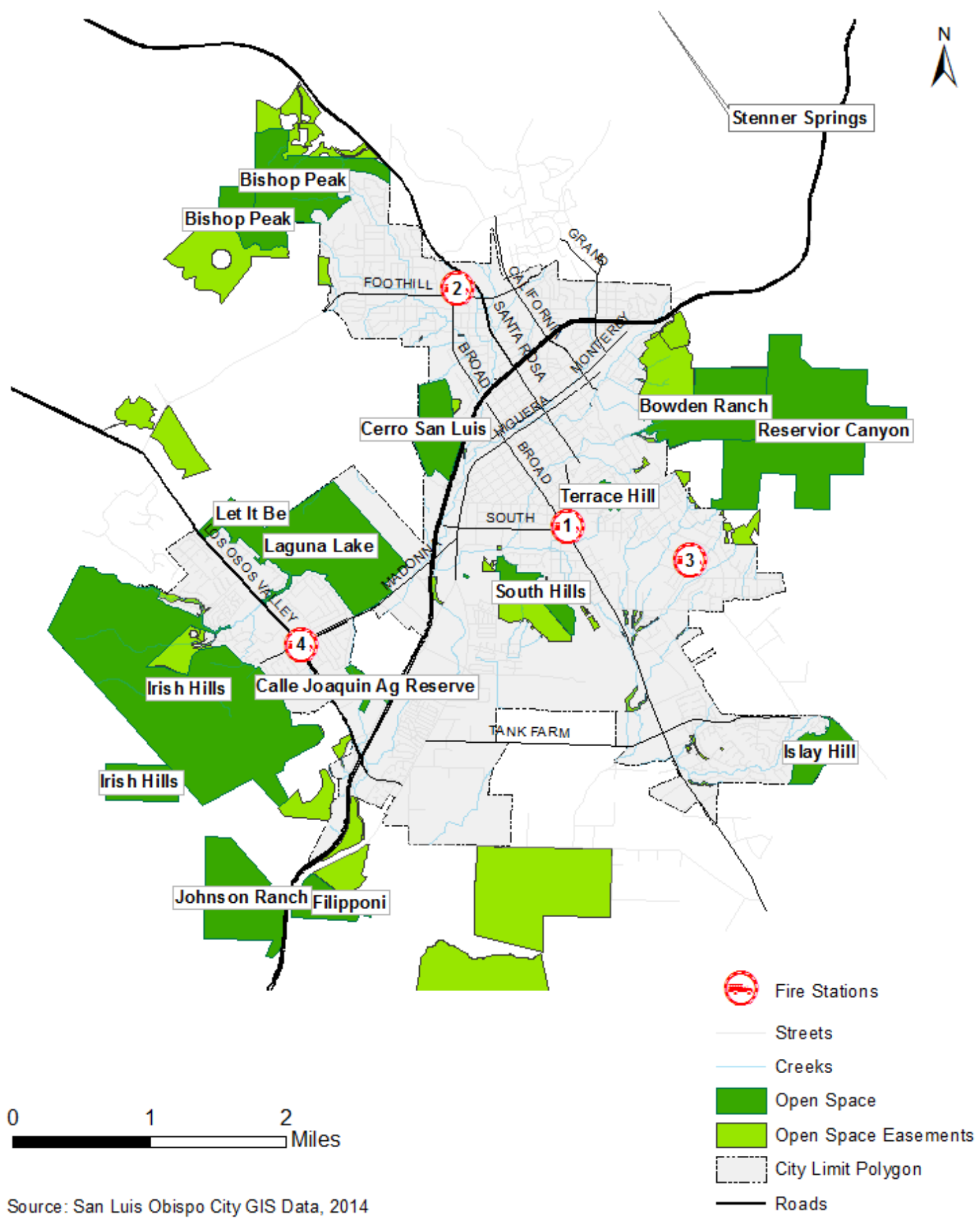

Figure 1. Open Spaces and Fire Stations in San Luis Obispo, CA. 


\section{Mutual and Automatic Aid Agreements}

There is an automatic aid agreement with CAL Fire that whichever agency is closest to the incident with available resources will respond, regardless if it is in city owned property or not. Any Open Space areas that are adjacent to the State Responsibility Area (SRA) is located in a Mutual Threat Zone; therefore, CAL Fire will also commit the resources to protect the area. The "State Responsibility Area" is an area where the State of California is financially responsible for prevention and suppression of wildfires.

\section{Values at Risk}

\section{Open Space}

The Open Space Properties that are addressed in this plan are as follows:

- Johnson Ranch

- Cerro San Luis

- Terrace Hill

- Irish Hills

- Laguna Lake

- South Hills

- Bishop Peak

- Reservoir Canyon Natural Reserve

o Reservoir Canyon

o Bowden Ranch

- Stenner Springs 


\section{Historical Data}

\section{Open Spaces and Fire History in San Luis Obispo, CA}

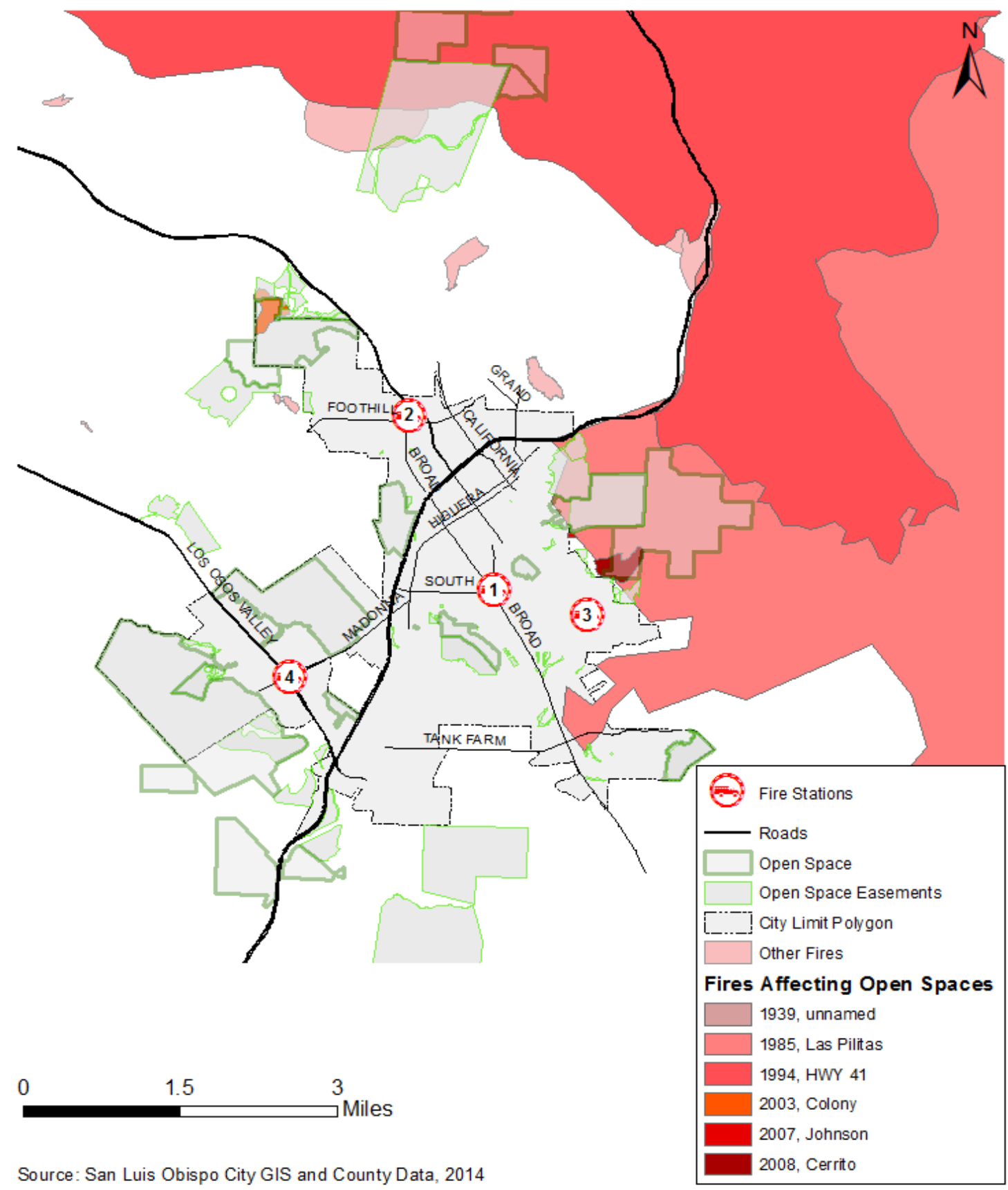

Figure 2. Open Spaces and Fire History in San Luis Obispo, CA. 
Description of the shape file:

CAL FIRE, USDA Forest Service Region 5, BLM, NPS, Contract Counties and other agencies jointly maintain a comprehensive fire perimeter GIS layer for public and private lands throughout the state. The data covers fires back to 1878. For the National Park Service, Bureau of Land Management, and US Forest Service, fires of 10 acres and greater are reported. For CAL FIRE, timber fires greater than 10 acres, brush fires, fires greater than 50 acres, grass fires greater than 300 acres, and fires that destroy three or more residential dwellings or commercial structures are reported. (CAL FIRE, 2013)

Open Space properties that were affected by these fires reported:

- Bowden Ranch

o Johnson, 2007

o Las Pilitas, 1985

- Reservoir Canyon

o Las Pilitas, 1985

o Cerrito, 2008

o HWY 41, 1994 approached Reservoir Canyon

- Stenner Springs

o Un-named, 1939

o HWY 41, 1994

- Bishop Peak

o Colony, 2003

NOTE: There have been other fires in the open space areas, but not reported on this GIS file due to their small size. A few of these fires were noted in the update to the San Luis Obispo Local Hazard Mitigation Plan. They were the Bishop Peak Fire, which took place in July of 2013 and was a " 1 acre brush fire near Bishop Peak in San Luis Obispo" (City of San Luis Obispo, 2014, p. 38). Another fire that occurred near open space areas was the Bowden Ranch Fire on August 27, 2013, described as a "small brush fire in San Luis Obispo" (City of San Luis Obispo, 2014, p. 38).

\section{Fire Hazard Severity Zones}

Fire Hazard Severity Zones are determined by CAL Fire. They were obtained from San Luis Obispo County GIS Data, and are given a ranking of Moderate, High, or Very High Severity. In wildfire preparedness, a "hazard refers to a fuel complex defined by its volume, type, condition, arrangement, and location" (Blonski, Miller, \& Rice, 2007, p. 7). Figure 3 shows a map of Fire Hazard Severity Zones in San Luis Obispo, and their proximity to Open Spaces. 


\section{Open Spaces and Fire Hazard Severity Zones in San Luis Obispo, CA}

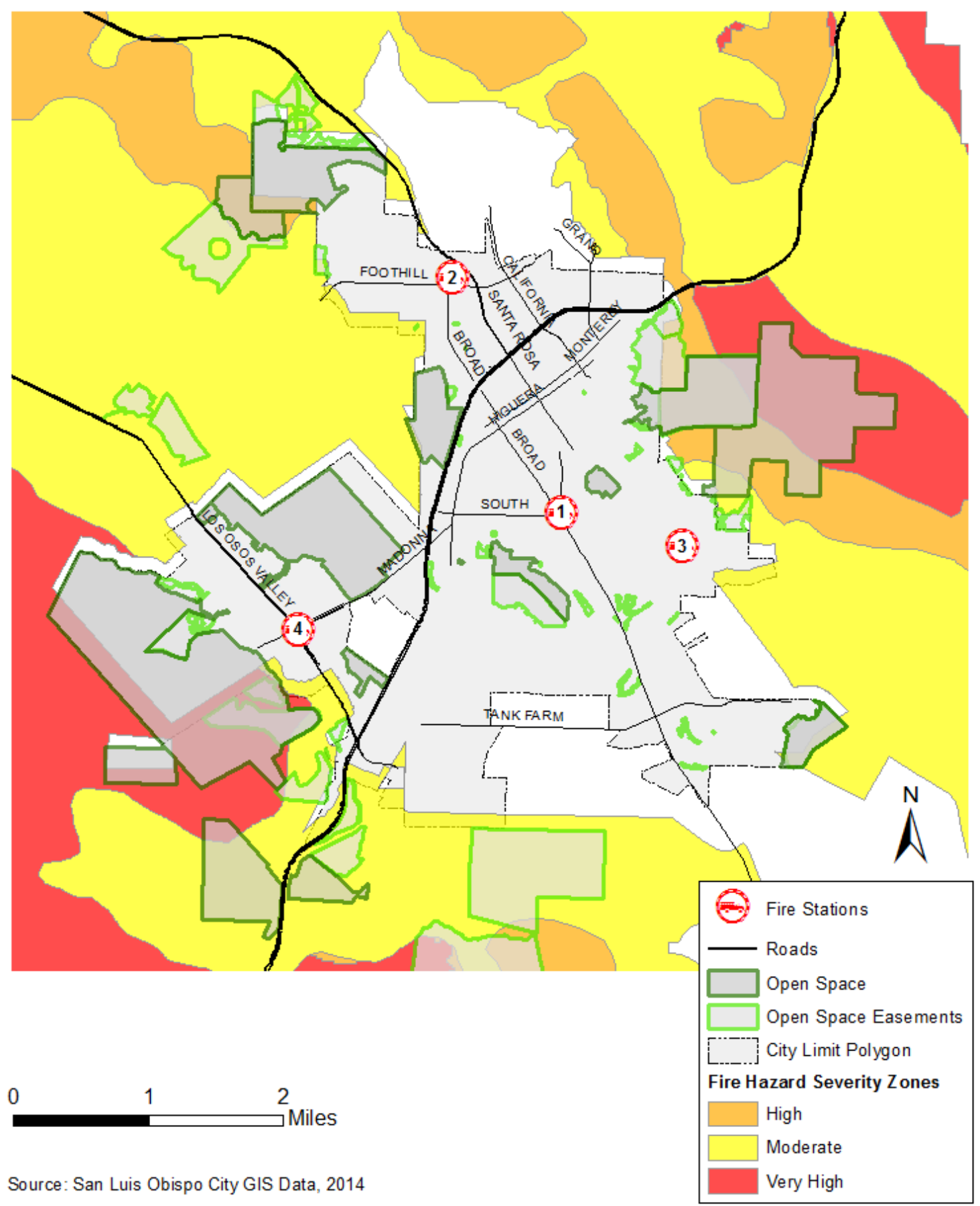

Figure 3. Open Spaces and Fire Hazard Severity Zones in San Luis Obispo, CA. 
Open Space Areas with Very High Fire Hazard Severity Zones:

- Irish Hills

- Johnson Ranch

- Reservoir Canyon

- Bowden Ranch

- Stenner Springs

Open Space Areas with High Fire Hazard Severity Zones:

- Bishop Peak

- Bowden Ranch

- Reservoir Canyon

Open Space Areas with Moderate Fire Hazard Severity Zones:

- Johnson Ranch

- Reservoir Canyon

- Stenner Springs

- Boarder of Bishop Peak

- Boarder of Cerro San Luis

- Boarder of Laguna Lake, however there is no overlap

Open Space Areas not located in Fire Hazard Severity Zones:

- Terrace Hill

- South Hills

- Laguna Lake 


\section{Pre-fire Planning}

There are multiple fire management strategies and tactics available for wildfire prevention and preparedness, such as providing adequate staffing and resources, requiring homeowners to have defensible space, and fuel or vegetation management. Some pre-fire management strategies that are going to be addressed and potentially used as projects are:

- Manual/Hand Labor

- Tree Removal

- Mechanical

- Prescribed Burning

- Grazing

- Chemical Treatment

Vegetation management is not a one-size-fits-all, and the procedure used at each location will vary. In order to determine the best management practice for each open space, there will be numerous factors to consider.

In Managing Fire in the Wildland Interface by Blonski, Miller, \& Rice (2010), there are several vegetation management techniques explained, including average costs, limitations, and advantages and disadvantages:

\section{Manual/Hand labor}

Skilled laborers prune, cut, or remove weeds or shrubs by hand or manual tools, such as a weed whip, "weed wrench," or chain saws, for example. This method is slow, yet selective, and is useful for small-scale sites. It is best used in spot applications and areas with sensitive environmental concerns. The timing can be staggered throughout the growing season, and some limiting factors such as poison oak or availability of labor should be taken into consideration. Some advantages are: it can be selective; it is possible to execute in most conditions; it is quiet; and there is the least amount of soil disturbance. Some disadvantages are that this method is expensive, slow, short term, and can be difficult to schedule. The cost can vary from $\$ 10,000$ to $\$ 1,500$ per acre, depending on the timing, size of the project, and level of specificity required.

\section{Tree removal}

Tree removal can vary from individual trees to removal of an entire overstory. This process can be selective with limited impacts, and also generates considerable debris that should be removed or sold commercially. Some limiting factors to consider are the social and political acceptance of tree removal, the topography of the area, and slope stability. Advantages of tree removal include: selectiveness, reducing of spotting 
potential, cost effectiveness, and potential commercial value. Disadvantages of tree removal are: expense, follow-up treatment and removal of debris, potentially restricting physical conditions, and erosion potential. Lastly, the cost can be approximately $\$ 3,000-$ 5,000 per acre.

\section{Mechanical}

Mechanical treatments, such as grading, chipping, mowing, involve the "removal of weeds, shrubs, and small trees with use of tractor or other machinery" (p. 343). This method is ideal for larger areas or for fuel breaks and is often used with other techniques and are usually maintained annually. Cost is about $\$ 500$ per day with a contracted service and can modify one-half acre an hour. Some limitations are that mechanical treatments cannot be used on slopes over $30 \%$, the machines can be hard to maneuver or be selective, the equipment can weigh up to 20 tons and cannot be used on unstable soils, and there is a concern for the distribution of exotic species. Advantages of mechanical treatments: some species may benefit from mowing, this process can be efficient in larger flat areas, it can be effective in poison oak, there are minimal health concerns, it is a relatively fast process, and it can be an appropriate roadside treatment. Some disadvantages are: grading can shift natural soil profiles, mowing or disking may disturb ground nesting birds or burrowing animals, there is a required scheduling and supervising process, the effects are generally short term machinery is not suitable for steep terrain, and there are considerable maintenance, noise, and access issues associated with the equipment.

\section{Prescribed Burning}

Prescribed burning is "reintroducing fire into the ecosystem," which reduces overall volume, increases moisture of remaining fuel by removing dead and dry material, reduces fuel bed height, and changes structure through vertical and horizontal separation (p. 345). There are a number of steps that need to be taken before a prescribed burn can be performed, such as coordinating with regulating agencies, obtaining approval and permits, and notifying the surrounding community and public agencies. Prescribed burning is most effective in certain vegetation such as grasslands, Eucalyptus groves, or oak woodland, and timing is critical due to weather constrictions. It is the "fasted, most thorough, and can be the least expensive method of removing fuel from an area" (p.345). Some advantages addressed are: that it is cost effective, it supports plants that have adapted to fire, it promotes new growth, it creates a naturalappearing boundary, it can be relatively quiet with minimal soil disturbance, it is effective in steep terrain or overstory, and it can release nutrients. Potential disadvantages of prescribed burning are: prescribed burning can be politically or socially unpopular, there is a minimum size of five acres, there is a risk of escaped fire, it requires extensive preparation, expertise, scheduling, equipment, coordination, and supervision, there are health considerations from smoke and poison oak, and there are short term visual impacts. 


\section{Grazing}

Grazing is the "intentional use of animals to consume vegetation, thus reducing the amount or density of fuel," is usually done through private contract or lease arrangements, and it can occur approximately once every three years or two successive years out of six (p. 346). Grazing is ideal for grass or shrub areas, and the costs can vary from $\$ 300$ to $\$ 1,000$ per acre. Some things to consider would be the foraging preferences of the animals, fencing, water sources, predators, availability of livestock, protection of certain plant species, and public safety. Some advantages are: it is a historical land use, minimal health concerns are involved, it is quiet, can be used in areas with overstory, there is potential for revenue, and it is an excellent tool for grasslands. Disadvantages of grazing are: availability of livestock, environmental concerns for soil erosion, sensitive species, and water quality, livestock do not necessarily eat all undesirable plants, there is sometimes a strong odor associated, it requires a specialized management, and there can be some visual impacts.

\section{Chemical Treatment}

Vegetation can be killed or reduced through chemical treatment in limited areas, however, public health and environmental concerns have limited the use of these treatments. Some techniques include: chemicals that prevent germination of seeds and kill sprouted plants for firebreaks and roadside treatments; Roundup and Garlon 4-a for eradication of eucalyptus resprouting; Foliar application with Roundup of French Broom and Eucalyptus resprouts; and roadside spraying in areas of high ignition risk. Although it can be fairly inexpensive, the repetition required makes this process costly.

Additionally, other limiting factors include: environmental sensitivity; timing; and effectiveness. Advantages of chemical treatment: the process is selective if done by hand; can be done in most physical conditions, such as wet ground and steep slopes; it is relatively quiet and quick; and there are minimal soil or erosion impacts. Some disadvantages: environmental and political sensitivity; expense; it requires follow up treatment; there are potential health hazards to the applicator, residents, and visitors; environmental damage to plants, wildlife, soil, water; timing; and government requirements.

Other necessary pre-fire planning techniques that should be utilized for pre-fire planning is fire prevention information and education of residents and people who use the open space property. This is especially important due to the risk of human-caused ignition, as well as to maintain trust and communication with residents when performing certain vegetation management techniques. This can be done through signage at the open space property, as well as through focused outreach activities with local residents. 


\section{Statutes and Regulations}

There a few statutes and regulations that pertain to vegetation management in the City of San Luis Obispo. There is the Municipal Code on Weed Abatement, the Conservation/Open Space Zoning Code, and the Public Resources Code Section 4291 regarding defensible space.

The City of San Luis Obispo's weed abatement program is written in Municipal Code 8.8: Hazardous Weeds and Debris, subsection "08.020 Nuisance declared - permitting accumulation of weeds and debris unlawful - permission required to burn weeds or debris," which states that "all weeds growing upon private property or streets in the city and all debris on private property or streets in the city are public nuisances. (City of San Luis Obispo, 2014). This makes the property owner responsible for removal of weeds and debris, which can be enforced by the City.

In the City of San Luis Obispo Zoning Regulations, "Chapter 17.32: Conservation/Open Space (C/OS) Zone" states that the purpose of the conservation and open space zone "is intended to prevent exposure of urban development to unacceptable risks posed by natural hazards and to protect natural resources from disruptive alterations" (City of San Luis Obispo, 2010, p. 96). Therefore, it is City responsibility to address potential fire hazards, and protect natural resources from damages.

Public Resources Code (PRC) Section 4291 - "Clearance around Structures" is about defensible space, which states:

"Any person that owns, leases, controls, operates, or maintains any building or structure in, upon, or adjoining any mountainous area of forest-covered lands, brush-covered lands, or grass-covered lands, or any land which is covered with flammable material, shall at all times:

(a) Maintain around and adjacent to such building or structure, a fire break made by removing and clearing away, for a distance of not less than 30 feet on each side thereof or to the property line, whichever is nearer, all flammable vegetation or other combustible growth. This subdivision does not apply to single specimens of trees, ornamental shrubbery, or similar plants which are used as ground cover, if they do not form a means of rapidly transmitting fire from the native growth to any building or structure.

(b) Maintain around and adjacent to any such building or structure, additional fire protection or fire break made by removing all brush, flammable vegetation, or combustible growth which is located from 30 feet to 100 feet from such building or structure or to the property line, whichever is nearer, as may be required by the director if he finds that, because of extra hazardous conditions, a fuel break of only 30 feet from such building or structure is not sufficient to provide reasonable fire and life safety. Grass and other vegetation located more than 30 feet and less than 18 inches in height above the ground may be maintained where necessary to stabilize the soil and prevent erosion. 
(c) Remove that portion of any tree which extends within 10 feet of the outlet of any chimney or stovepipe.

(d) Maintain any tree adjacent to or overhanging any building free of dead or dying wood.

(e) Maintain the roof of any structure free of leaves, needles, or other dead vegetative growth.

(f) Provide and maintain at all times a screen over the outlet of every chimney or stovepipe that is attached to any fireplace, stove, or other device that burns any solid or liquid fuel. The screen shall be constructed of nonflammable material with openings of not more than one-half inch in size.

(g) The director may adopt regulations exempting structures with exteriors constructed entirely of nonflammable materials, or conditioned upon the contents and composition of same, he may vary the requirements respecting the removing or clearing away of flammable vegetation or other combustible growth with respect to the area surrounding said structures.

No such exemption or variance shall apply unless and until the occupant thereof, files with the department, in such form as the director shall prescribe a written consent to the inspection of the interior and contents of such structure to ascertain whether the provisions hereof and the regulations adopted hereunder are complied with at all times" (California Department of Forestry and Fire Protection, 2000).

This code is enforced in the City, specifically near Open Space areas that are a fire hazard. 


\section{Context}

There are 12 large Open Space lands totaling about 4,000 acres, as well as additional conservation easements, all operated by the City. Each Open Space property in San Luis Obispo is unique, with various topography, vegetation, and access points. For each Open Space, there is a description of the following:

- General Description
o Location
o Fuel/Vegetation
o Topography

- Assets at Risk/Structures

- Access

- Water Supply

- Evacuation Routes

- Predominant Risk Exposure

- Pre-Fire Plan and Proposed Projects with a Priority Ranking

Background information was collected from existing Open Space Conservation Plans, San Luis Obispo City and County GIS Data, and collaboration with the City Fire Marshall and Natural Resources Manager.

\section{Vegetation}

Vegetation for each Open Space was analyzed based upon GIS Data from the City and from Open Space Conservation Plans.

GIS Data from the City of San Luis Obispo was utilized to determine the vegetation. This data is more detailed than the County GIS Vegetation Data, and contains the following Types and (Categories):

1. Bay-Oak Woodland

2. Cactus Scrub

3. Chaparral

4. Coastal Sage Scrub (Scrub Habitats)

5. Cultivated Crops

6. Eucalyptus Woodland

7. Freshwater Marsh

8. Non-native Grassland

9. Oak Riparian

10. Oak Woodland (Woodland Habitats)

11. Oak-Sycamore-Bay Riparian 

12. Open Water
13. Other Mixed Riparian
14. Potential Wetland
15. Ruderal (Agricultural/Disturbed Habitats)
16. Seasonal Wetland
17. Serpentine Chaparral (Grassland Habitats)
18. Serpentine Coastal Sage Scrub
19. Serpentine Grassland (Grassland Habitats)
20. Sycamore Riparian
21. Urban Area Dominated By Buildings or Paving (Developed Habitats)
22. Urban Area Dominated by Tree Canopy, Landscaping
23. Willow Riparian
24. Willow-Sycamore Riparian

There were a few discrepancies in the GIS data and consistency between the City Data and a few of the approved Conservation Plans, and those discrepancies are addressed in Appendix B.

Some portions of Stenner Springs Open Space did not have data from the City Vegetation data, therefore the County GIS Vegetation data was used. Additionally, information was derived from the Stenner Springs Natural Reserve Draft Conservation Plan. For the County GIS Vegetation data that was used, the description of the shape file, titled "PLN_VEG_SLOCO_2007," states that it was created in $\mathbf{2 0 0 8}$ to provide a "baseline structural vegetation map and oak survey for the entire county" and adheres to the "National Vegetation Classification System" (County of San Luis Obispo, 2008).

\section{Assets at Risk and Structures}

Assets at risk can be structural or biological. For each open space, there are assets potentially at risk, including infrastructure such as houses, water tanks, and power lines. There could also be rare or endangered species or vegetation, scenic views, or recreation areas that are considered assets in the area.

\section{Access}

This section is based on routes to trailheads and any dirt, paved, or graded access road that is on or near the open space property which can be used for maintenance or emergency purposes.

\section{Water Supply}

Water supply is based on access to fire hydrants near the open space properties and any bodies of water that could be utilized in firefighting. 


\section{Predominant Risk Exposure}

A fire risk is the chance of a fire starting, based upon "the presence and activity of causative agents" (Blonski, Miller, \& Rice, 2007, p. 360). Risks of fire can be natural, such as lightening, or man-made, such as from cigarettes or machinery sparking.

\section{Wildfire Preparedness Plan}

This section restates the Fire Hazard Severity Zone for the property. It also addresses the projects currently occurring in the Open Spaces as outlined in the Conservation Plans, or projects that could take place in the future to manage vegetation and reduce fire hazard on the property. Furthermore, it lists potential future considerations for vegetation management. It then gives a priority ranking, described below.

\section{Priority Ranking Criteria}

Each Open Space is given a Priority Ranking of High, Medium, or Low, based upon evaluation of particular characteristics. The following criteria are taken into account:

- Vegetation

- Topography

- Assets

- Fire history

- Probability of future events 


\section{Johnson Ranch Open Space Aerial Map}
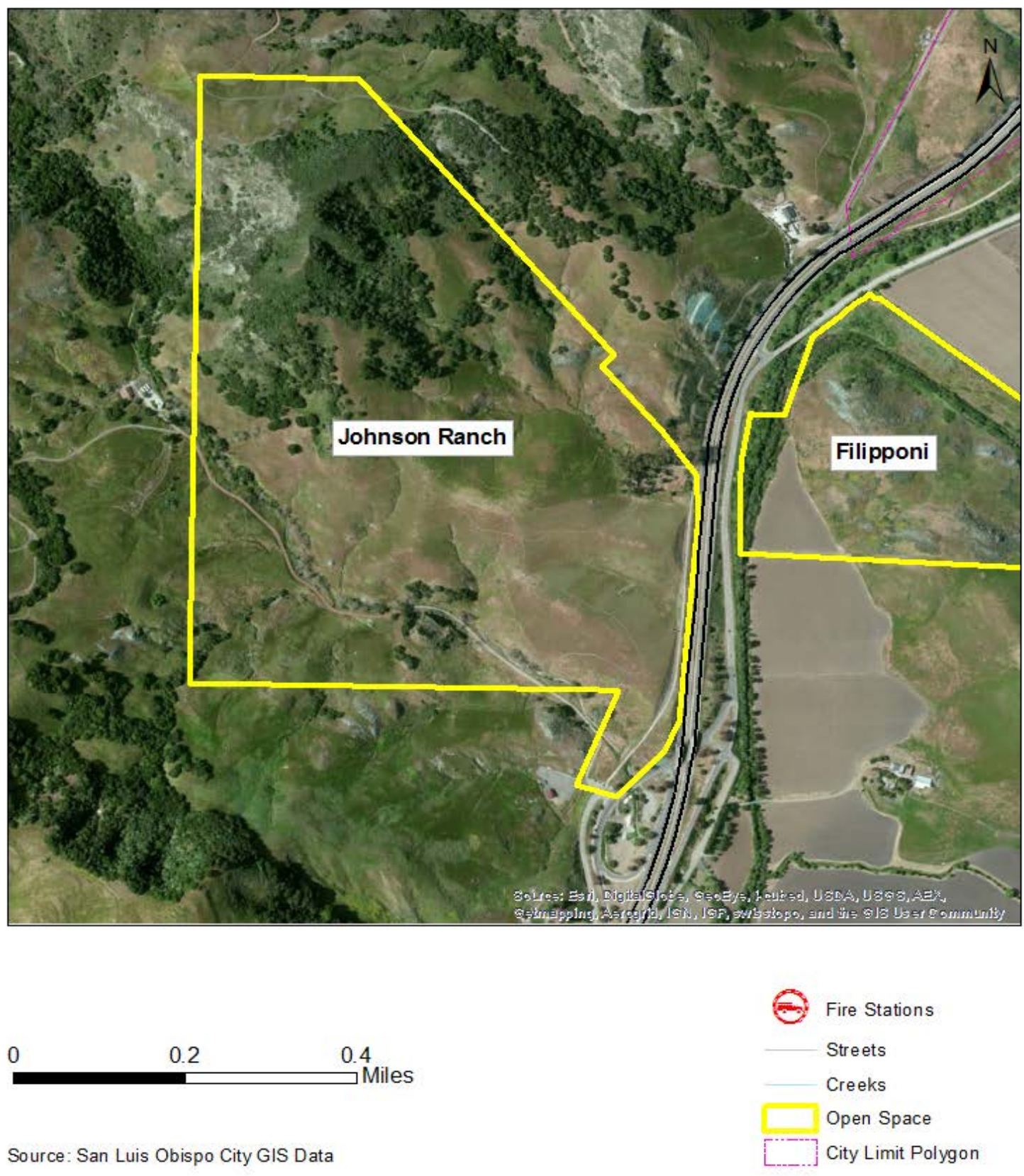

Figure 4. Johnson Ranch Aerial Map. 


\section{Description}

\section{Location}

Johnson Ranch is 242 acres, and is located about 1.5 miles south of the City of San Luis Obispo on the west side of US Highway 101.

\section{Closest Fire Station: Fire Station 4}

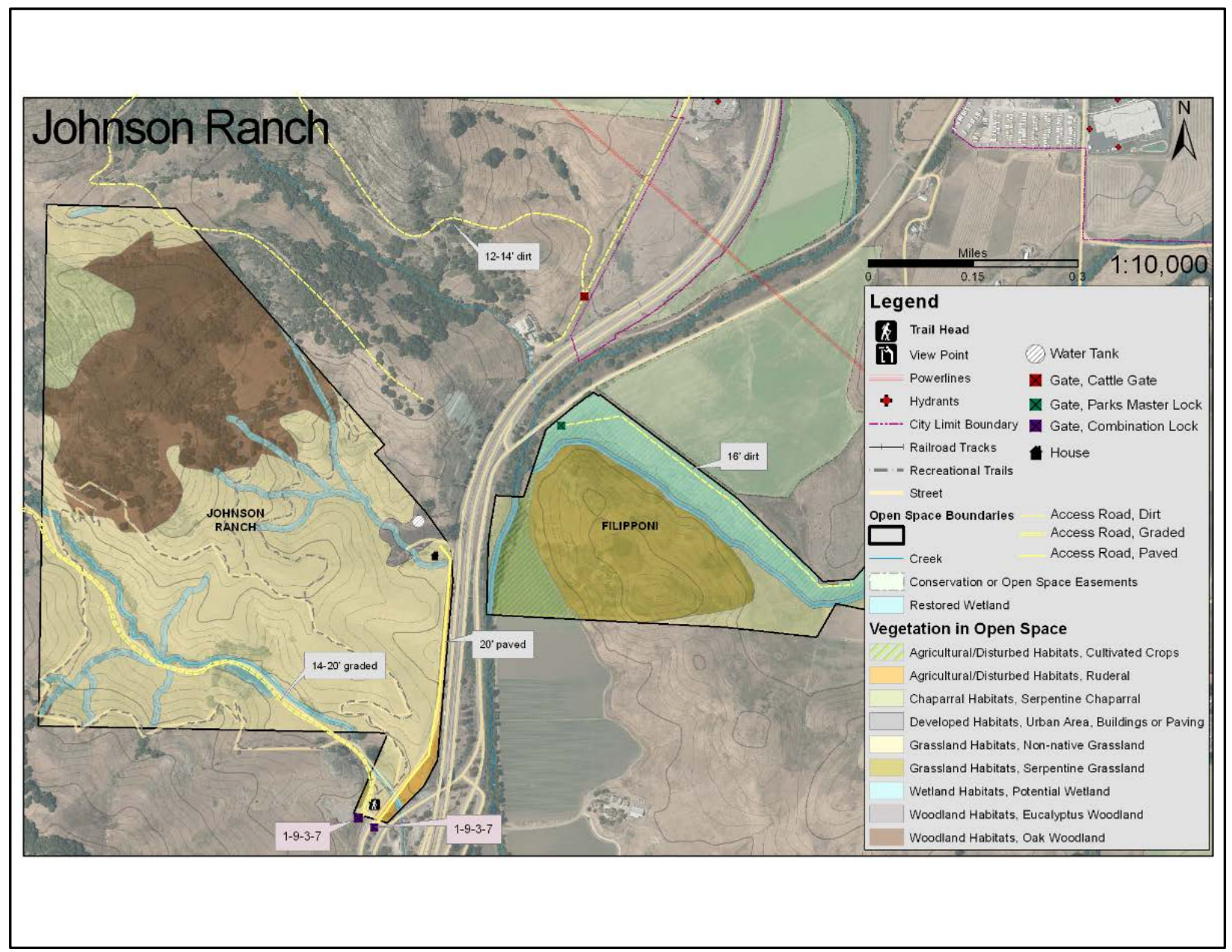

Figure 5. Johnson Ranch Map. 


\section{Johnson Ranch Vegetation Map}
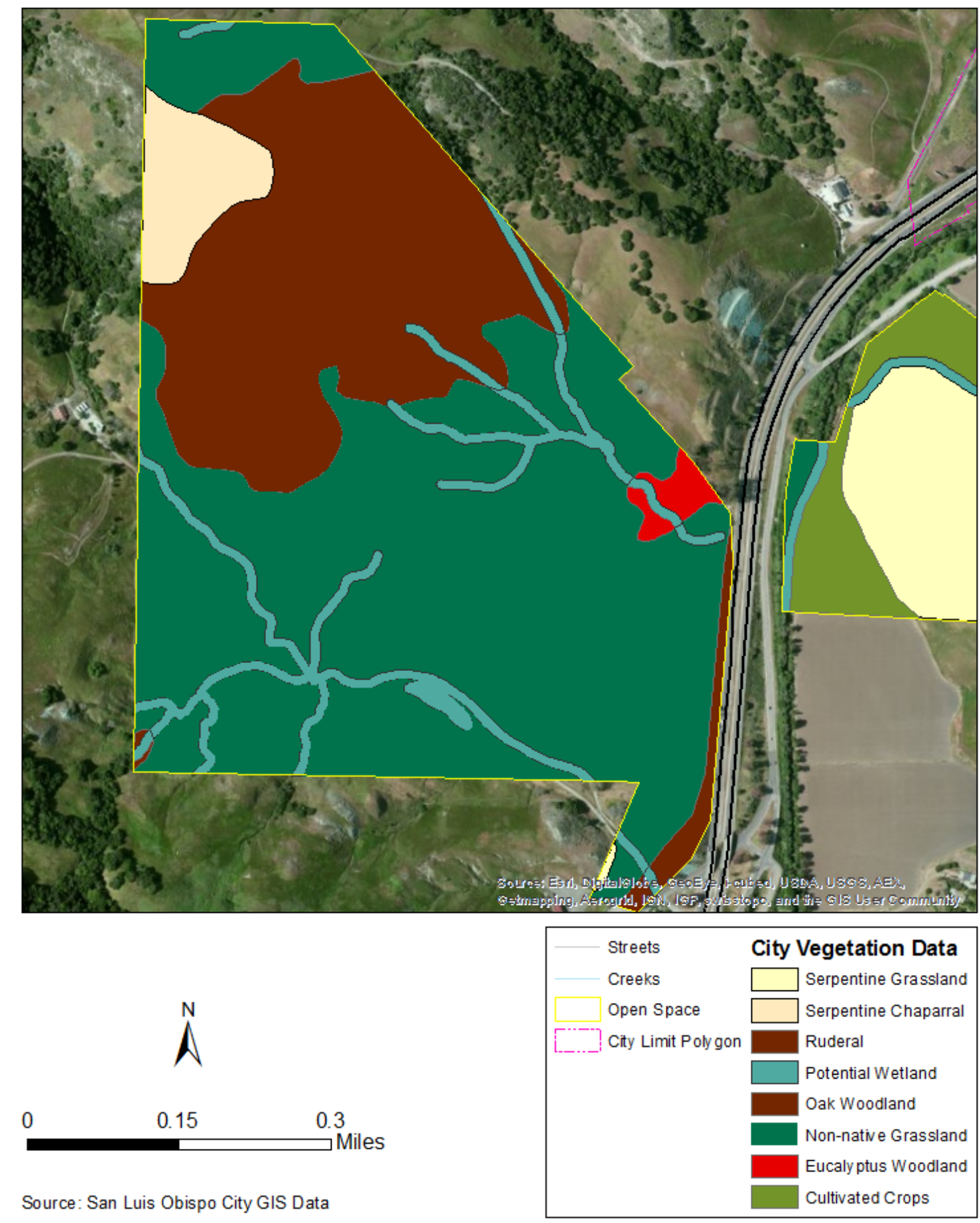

Figure 6. Johnson Ranch Vegetation Map. 


\section{Fuel/Vegetation}

The vegetation in Johnson Ranch consists of Non-native Grassland, Potential Wetlands, Oak Woodland, Eucalyptus Woodland, Ruderal, Serpentine Grassland, and Serpentine Chaparral.

Oak woodland covers about 65 acres on the northern slope of the property.

A majority of the vegetation is Non-native Grassland, located north and south of the Oak Woodland. The northernmost portion is about 8.5 acres, and the rest is located to the south of the Oak Woodland, totaling about 130 acres.

Almost 10 acres of Serpentine Chaparral is found in the northwest portion of the site.

Eucalyptus Woodland is found in the eastern corner of the property and covers approximately 2 acres.

There are potential wetlands found throughout the Open Space along the creeks, concentrated in: the southwest corner covering about 9.5 acres; southeast of the Oak Woodland, totaling about 6 acres; and in the northernmost section of the property, totaling less than a half-acre.

\section{Topography}

Elevation ranges from 80 feet above sea level at the south eastern corner of the property to 761 feet above sea level atop the hill on the northern portion of the site.

\section{Assets at Risk/Structures}

- Buildings on the Johnson Ranch property:
o five sheds
o two barns
o one residence

\section{Access}

The trailhead for the Johnson Ranch Open Space is located at the turnout to the intersection of South Higuera Street and Ontario Road.

There is also a $20^{\prime}$ wide partially paved road used to access the farmhouse on the property, which is used as a residence.

There is another $14^{\prime}-20^{\prime}$ graded road that provides legal access to a neighboring property to the west and is part of an easement which goes along the edge of Dry Creek about 0.75 miles.

Adjacent to the northeastern part of the property is a $12^{\prime}-14^{\prime}$ dirt road that is accessible off of the residential area through a cattle gate. 


\section{Water Supply}

Water resources are limited. There is Dry Creek, which is a small stream that enters Johnson Ranch from the adjacent Miramonte Ranch on the west, and flows in a southeasterly direction for about 0.75 mile to the easterly boundary.

\section{Evacuation Routes}

The turnout to the intersection of South Higuera Street and Ontario Road to HWY 101.

\section{Historical Data}

There is no history of major fires at this open space.

\section{Predominant Risk Exposure}

This Open Space is located off of HWY 101, which is a high risk for fire started by vehicles or people.

\section{Wildfire Preparedness Plan}

\section{Fire Hazard Severity Zone}

Very High \& Moderate

\section{Current Pre-Fire Plan}

The following is from the Jonson Ranch Open Space Conservation Plan:

Due to the fact that Johnson Ranch Open Space is outside of the developed area of the City, if wildfire is to break out, the most attention would be to protecting the buildings on the property. Approximately $60 \%$ of the property is grassland and is grazed which limits the fuel available for fire, but there is chaparral located at the top of the ridge and a grove of eucalyptus trees is located adjacent to the buildings. An active fire hazard abatement program is underway around the buildings and forest litter from the eucalyptus trees is periodically removed to reduce the fuel loading in the area. Mechanical control of fires within the chaparral areas would not be undertaken, due to the steepness and relatively small size of the area. Rangeland fires can be easily contained on the boarders of the chaparral.

Approximately $60 \%$ of the property is grassland and allows grazing, which is currently on a month to month lease. Cattle have access to the entire property. There are fences that are creating two pastures, and one being constructed to prevent livestock from accessing the riparian corridor. A third pasture will be established in the triangular area south of Dry Creek. Grazing will occur generally from March 1 to November 1 , and adjusted as necessary due to water supply and forage conditions. (Havlik \& Otte, 2008, p. 16)

Additionally, there is a tractor that mows along the US 101 Frontage. 


\section{Future Considerations}

If it is ever appropriate to do a prescribed burn, this property would be optimal to consider.

\section{Priority Ranking: High}

Based upon the fact that this area is in the Very High Fire Hazard Severity Zone, hazardous vegetation such as chaparral on the property, and assets at risk, as well as potential risk from being located near the freeway, Johnson Ranch is a high priority to continue to manage. There is already an abatement program underway on the property, and forest litter is removed periodically from Eucalyptus trees. This should continue on a regular schedule. 


\section{Cerro San Luis Natural Reserve Aerial Map}
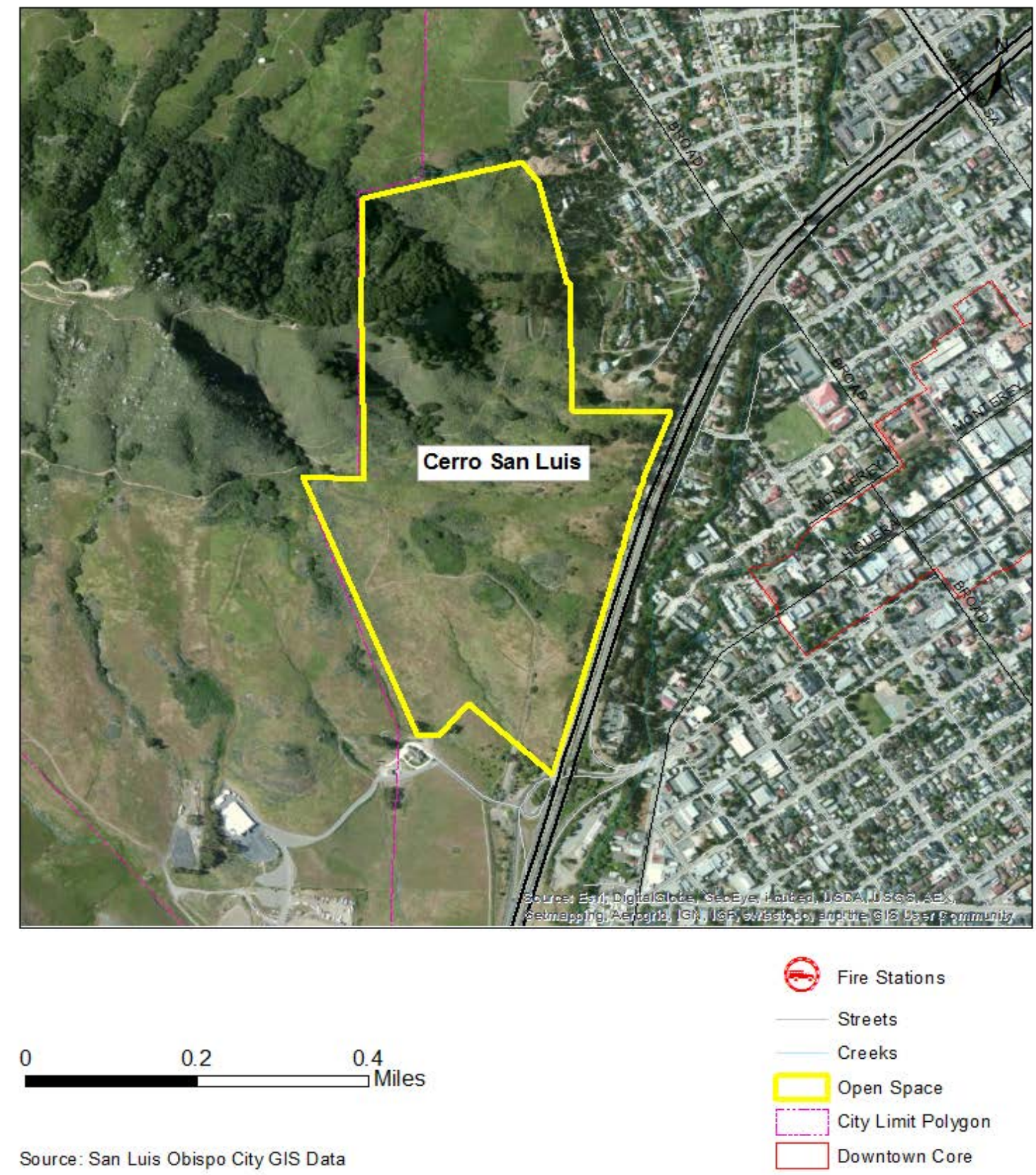

Source: San Luis Obispo City GIS Data

Figure 7. Cerro San Luis Aerial Map. 


\section{Description}

\section{Location}

Cerro San Luis Natural Reserve is about 118 acres, north of the Marsh Street on-ramp on the Southbound US Highway 101, with US Highway 101 bordering the area to the east.

Closest Fire Station: Fire Station 2

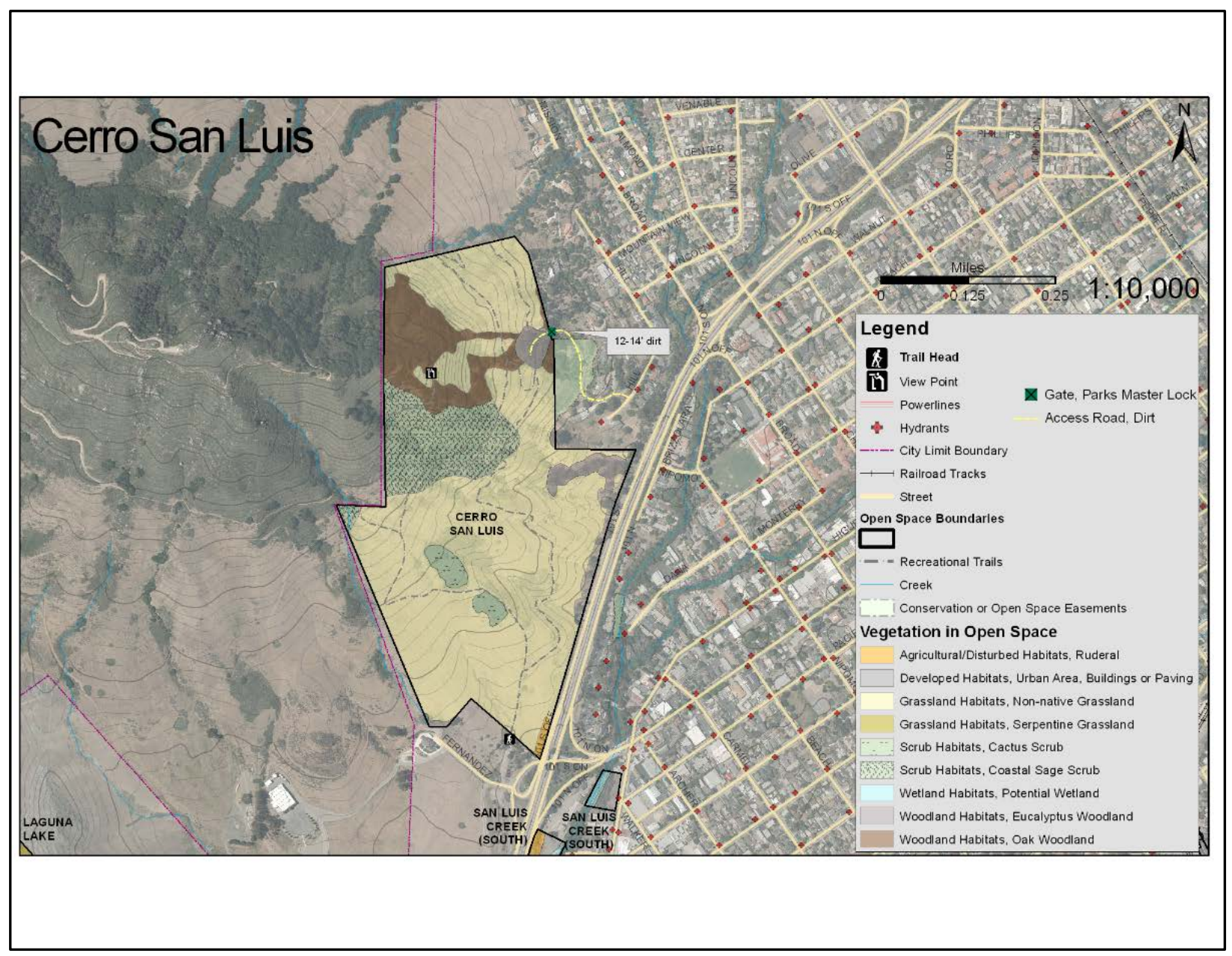

Figure 8. Cerro San Luis Map. 


\section{Cerro San Luis Natural Reserve Vegetation Map}

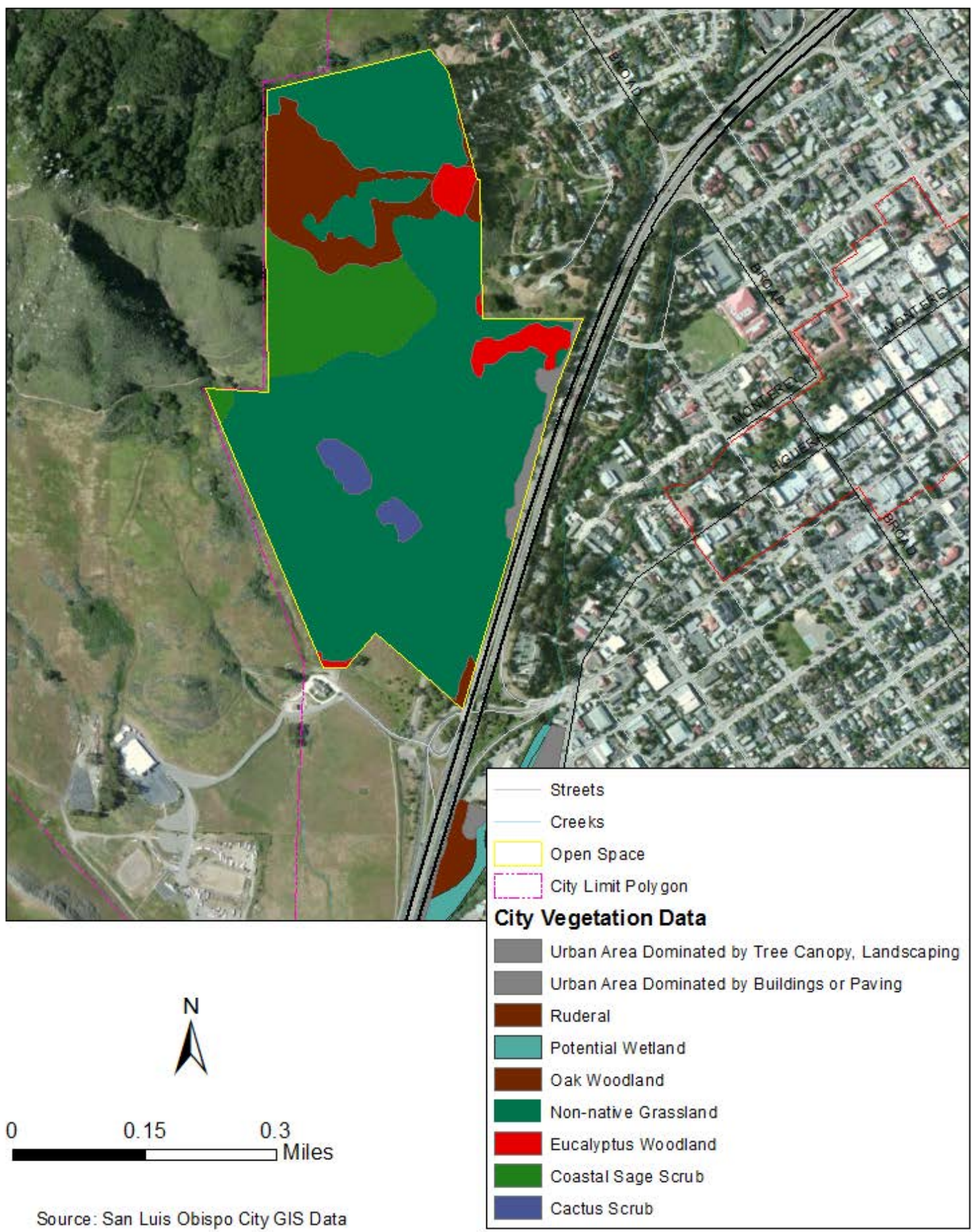

Figure 9. Cerro San Luis Vegetation Map. 


\section{Fuel/Vegetation}

Mostly Non-native Grassland, covering about 76 acres on the middle and lower slopes of Cerro San Luis

Oak Woodland covers about 12 acres near the northwest boundary

About 14 acres of Coastal Sage Scrub in the northwest

A few patches of Eucalyptus Woodland on the east side and southernmost boundary, totaling approximately 4 acres

About two acres of Cactus patches.

\section{Topography}

Generally moderate to steep slopes and elevations range from about 190 feet along the US Highway 101 easement to about 920 feet along the western boundary (City of San Luis Obispo Natural Resources Protection Program, 2005).

\section{Assets at Risk/Structures}

- Sensitive Habitats: Immediately south of Cerro San Luis Natural Reserve is a roosting site for monarch butterflies.

- The " $M$ " on the hillside facing downtown has been determined as historic or cultural significance to the community by the City's Cultural Heritage Committee.

- Two archeological sites are located on the open space.

- The northeast and eastern section is bordered by developed residential neighborhoods.

- Adjacent neighborhoods in the northwest

\section{Access}

Turn right onto Fernandez Road just before the southbound 101 Marsh Street on-ramp.

For maintenance use: there is a common driveway serving private residences at 663,665 , and 667 Hill Street. There is a 12-14' dirt access road off of Hill Street.

\section{Water Supply}

Hydrants are located at the end of Hill Street at the northeastern access.

\section{Evacuation Routes}

From the Fernandez road access point, exit from Fernandez Road onto the southbound 101 Marsh Street on-ramp.

From the southern access point of Hill Street, head North on Hill and then East on Lincoln. From the northern part of Hill Street, head south on Hill and east on Mountain View. 


\section{Historical Data}

There is no history of major fires at this open space.

\section{Predominant Risk Exposure}

This area is frequented often by recreational users, increasing risk of human caused ignition. It is also located in close proximity to homes and HWY 101.

\section{Wildfire Preparedness Plan}

\section{Fire Hazard Severity Zone}

Moderate Fire Hazard Severity Zone

\section{Current Pre-Fire Plan}

As per the "Cerro San Luis Natural Reserve Conservation Plan," there are three areas designated to fire management:

Fuel Management Area - area adjacent to the urban/wildland interface that couldn't be safely burned in a controlled manner. These areas require active pruning, mowing and/or other active management of the vegetation (including livestock grazing) to reduce fuel loads adjacent to developed properties. This includes most of the grassland areas of Cerro San Luis, and especially for the eucalyptus plantation on the easterly boundary near Hill Street. The city has an easement to access the Eucalyptus groves for thinning.

Active Firefighting Area - areas acting as a buffer between the surrounding urban developments and the pristine habitat. Active firefighting techniques such as the use of heavy machinery and cutting of fuel breaks can be utilized to protect property from an advancing wildfire.

These areas have also been identified because the physical resources and topography are conducive to successful restoration efforts following a wildfire.

Passive (habitat sensitive) firefighting area - Areas of important wildlife habitat, mostly on steep hillsides. These areas are also somewhat removed from urban development. They are particularly sensitive to aggressive firefighting techniques such as the use of heavy machinery. Therefore, wherever practicable, firefighting strategies in these areas should be limited to low impact, habitat friendly methods. (Havlik \& Clarke, 2005, p. 32).

Additionally, there is Livestock Grazing through Madonna Construction, Inc., which uses a rotational grazing system. Grazing is monitored annually and is permitted throughout the year, but the south pasture is avoided from December through February and avoided in the north pasture from December through March. (Havlik \& Clarke, 2005, pp. 32-34). 


\section{Priority Ranking: High}

This area is located in a Moderate Fire Hazard Severity Zone, with hazardous vegetation such as patches of eucalyptus, and there are numerous assets to protect on and near the property.

However, there is continuous vegetation management through grazing and thinning that takes place, which keeps the fire hazard low. There are no proposed fire management projects for this open space, other than continuous management that is already taking place through thinning and active grazing to reduce fuel loads and continue to keep the hazards to a minimum. 


\section{Terrace Hill Open Space Aerial Map}
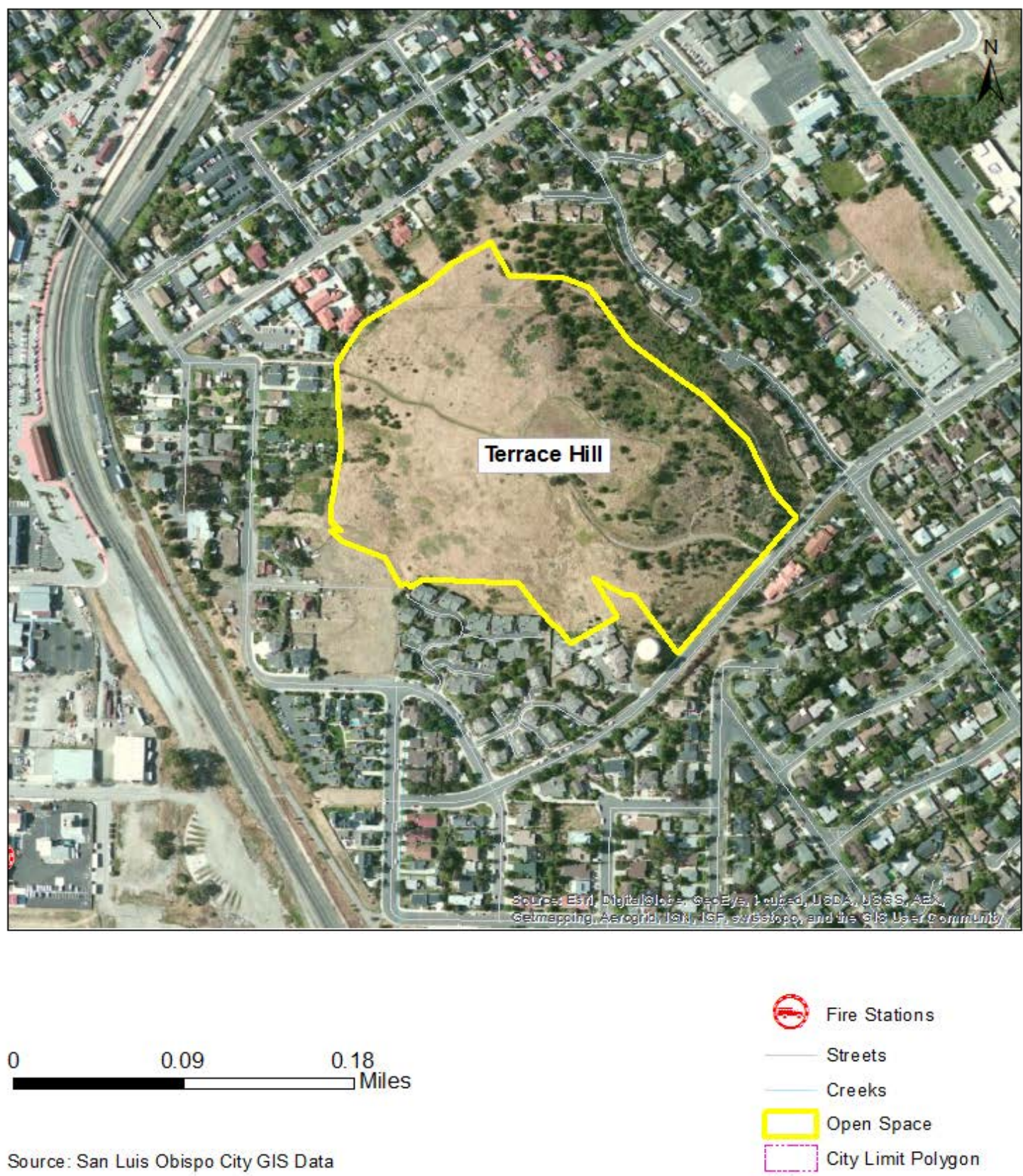

Source: San Luis Obispo City GIS Data

Figure 10. Terrace Hill Aerial Map. 


\section{Description}

\section{Location}

Terrace Hill is 22 acres and located on the east side of the city, between the Railroad Recreation Train to the west, Johnson Avenue on the east side, Ella Street on the north side and Bishop Street on the south side.

Closest Fire Station: Fire Station 1

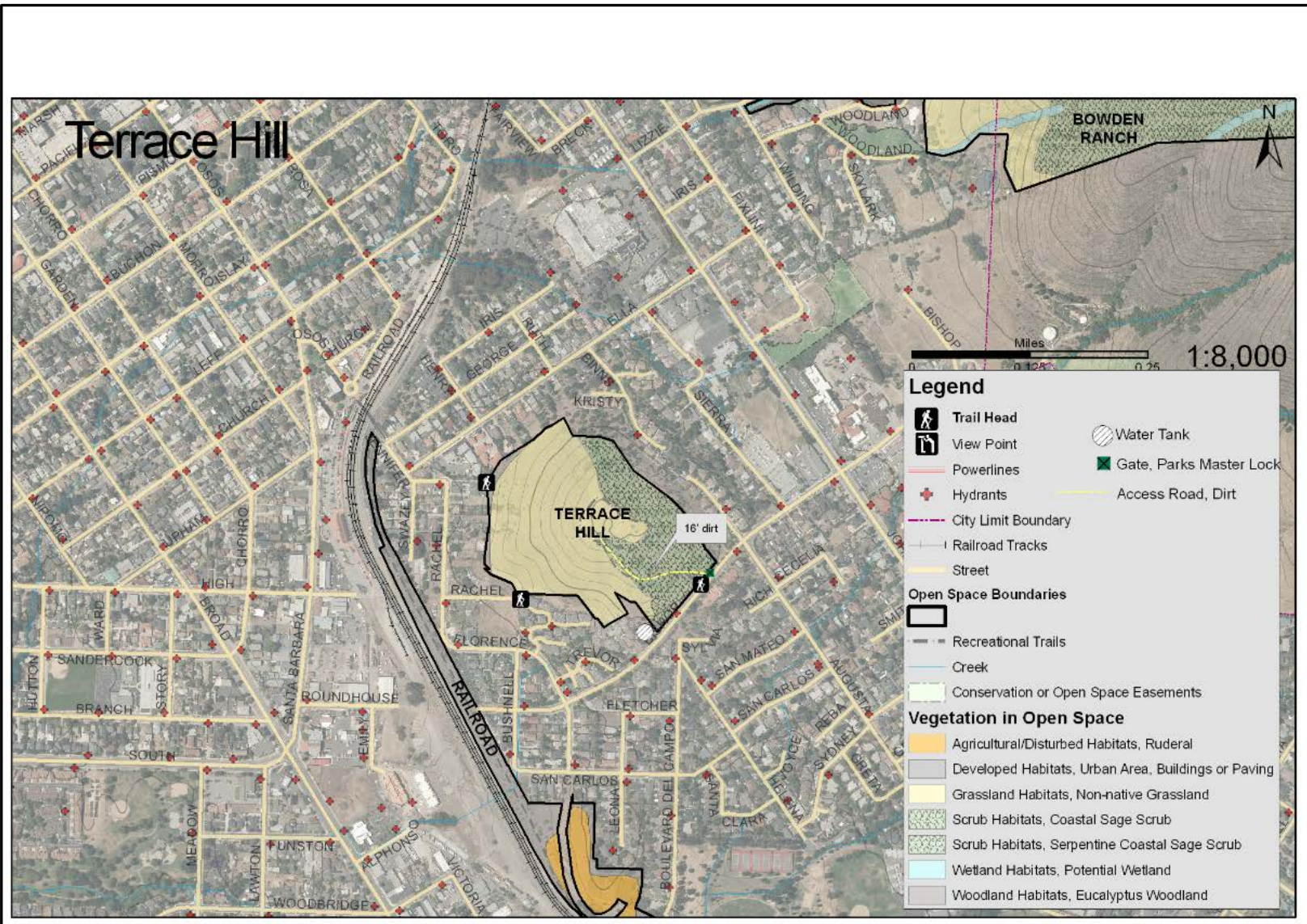

Figure 11. Terrace Hill Map. 


\section{Terrace Hill Vegetation Map}

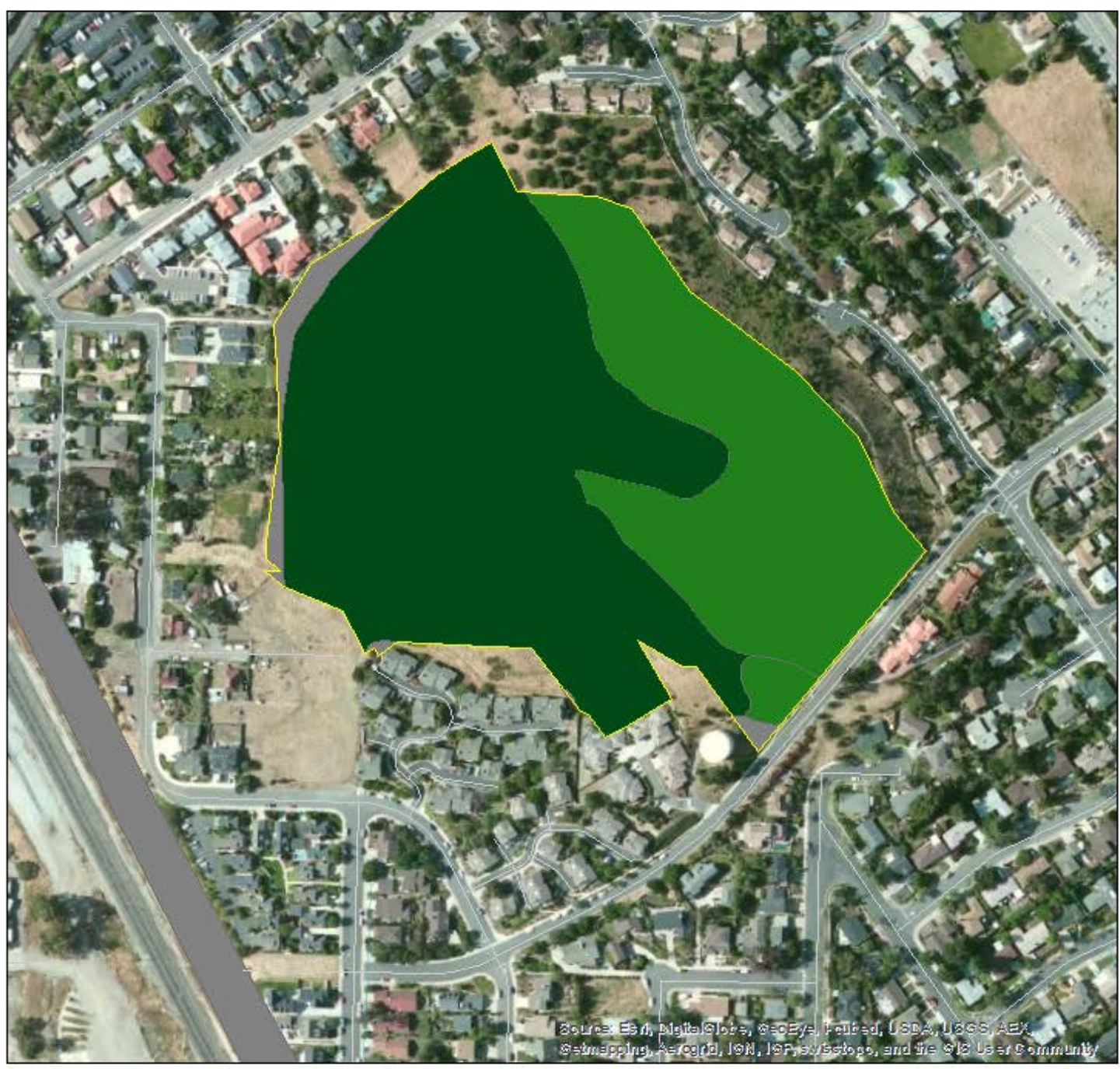

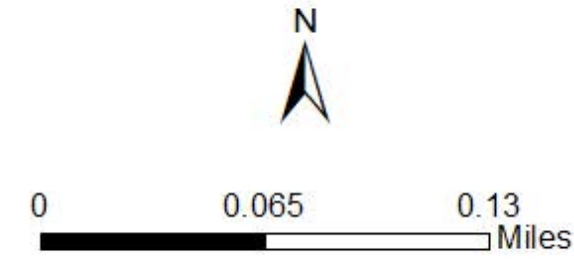

Source: San Luis Obispo City GIS Data

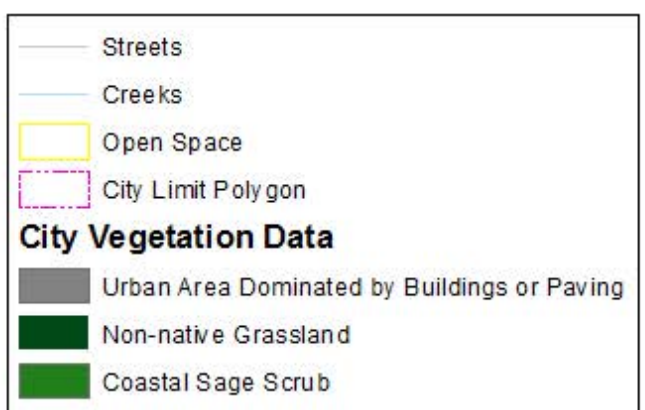

Figure 12. Terrace Hill Vegetation Map. 


\section{Fuel/Vegetation}

There is about 14 acres of Non-native Grassland on the west side and about 7 acres of Coastal Sage Scrub on the east side.

\section{Topography}

The elevation of Terrace Hill goes from approximately $300 \mathrm{ft}$. to $500 \mathrm{ft}$.

\section{Assets at Risk/Structures}

- The area is surrounded by residential property.

- There is also a water tank located south of the property.

\section{Access}

Trailhead is located on Bishop Street off of Johnson Avenue. There is a $16^{\prime}$ dirt access road off of Bishop Street.

There is also limited access from Binns Court, off of Ella Street from Johnson Avenue, as well as limited access from Augusta Court north of Bishop Street off of Johnson Avenue.

\section{Water Supply}

There are fire hydrants located along Bishop Street, as well as on Binns Court and Augusta Court.

\section{Evacuation Routes}

Evacuation would be northeast on Bishop Street and south on Johnson Avenue. Also, Northeast on Ella St and North on Johnson Avenue.

\section{Historical Data}

There is no history of major fires at this open space.

\section{Predominant Risk Exposure}

Terrace Hill is surrounded by residential areas, which could pose a risk for human caused fires.

\section{Wildfire Preparedness Plan}

\section{Fire Hazard Severity Zone}

Terrace Hill is not located in a Fire Hazard Severity Zone

\section{Current Pre-Fire Plan}

- There is currently mowing on top of the hill

- There is also mowing behind housing that comes up the property

- East side of the property should be doing its own weed abatement 


\section{Future Considerations}

The side slopes are at about a 30\% grade, making it too steep for mowing. Potential for livestock grazing of goats or sheep, granted that a contractor would be confident the livestock wouldn't escape or if there were fencing put in place.

\section{Priority Ranking: Low}

Terrace Hill is mostly grassland and scrub, and not a high fire hazard, especially considering there is continuous mowing. This should be continued. 


\section{Irish Hills Natural Reserve Aerial Map}
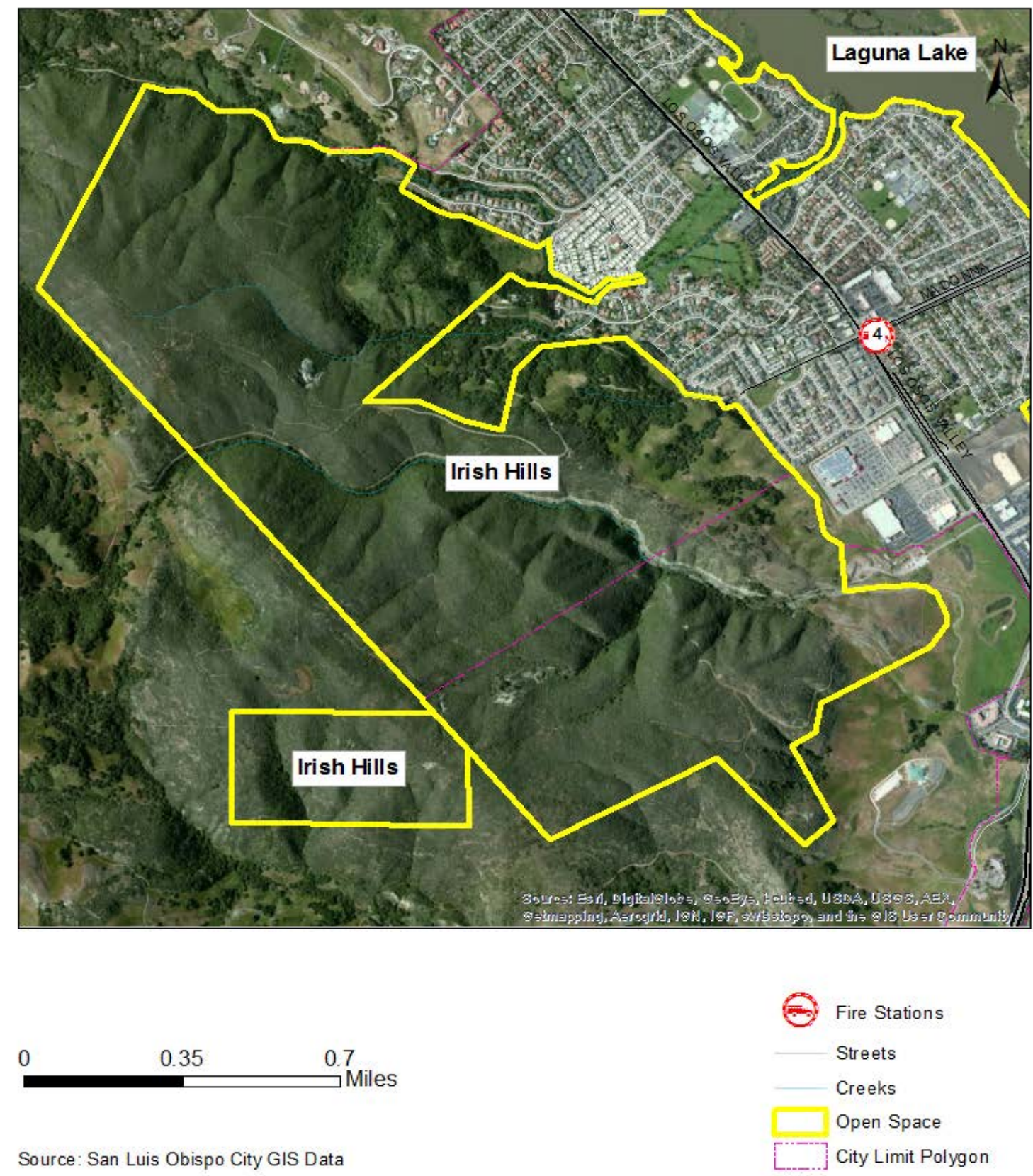

Figure 13. Irish Hills Aerial Map. 


\section{Description}

\section{Location}

Irish Hills Natural Reserve is about 1,110 acres, located west of Los Osos Valley Road, south of Prefumo Canyon Road.

\section{Closest Fire Station: Fire Station 4}

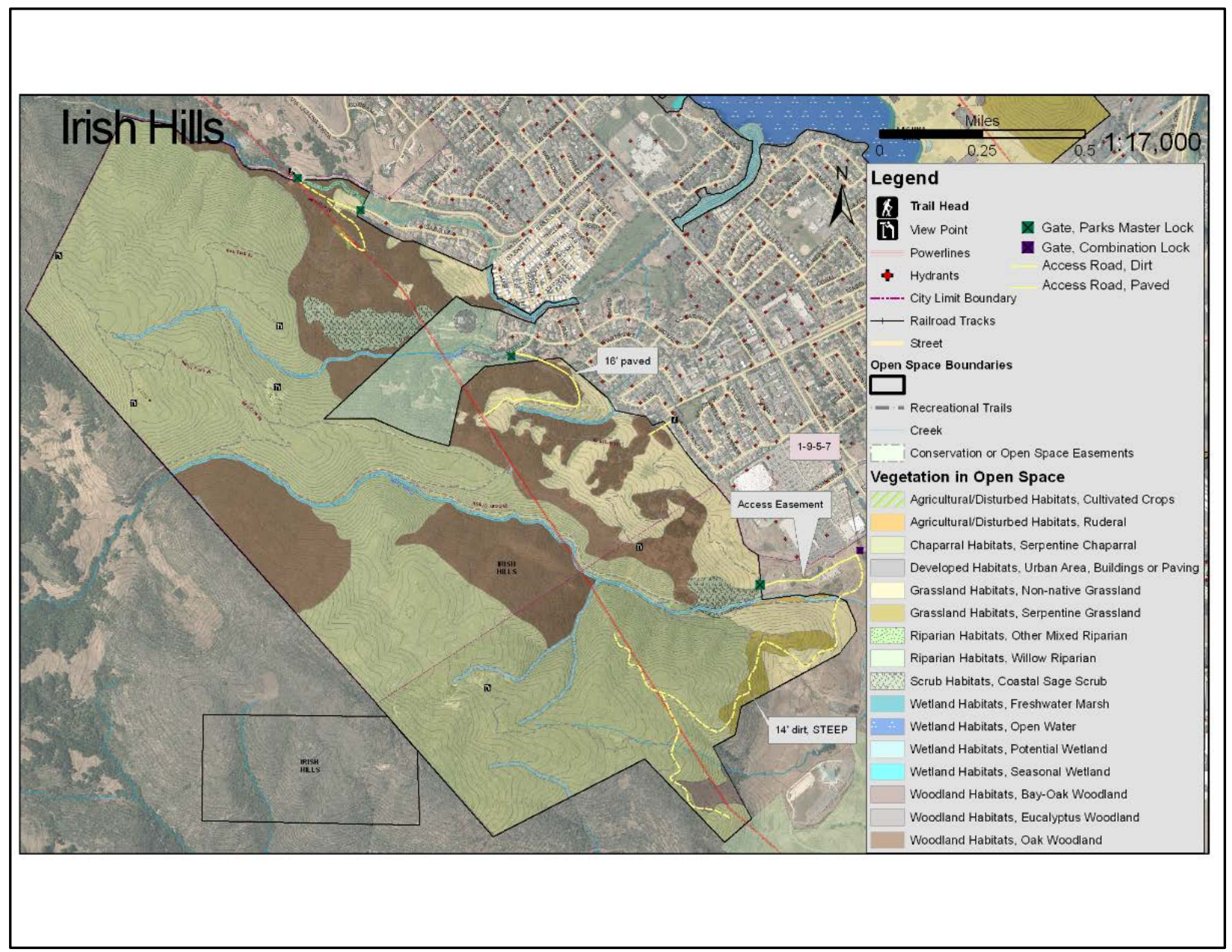

Figure 14. Irish Hills Map. 


\section{Irish HIlls Natural Reserve Vegetation Map}

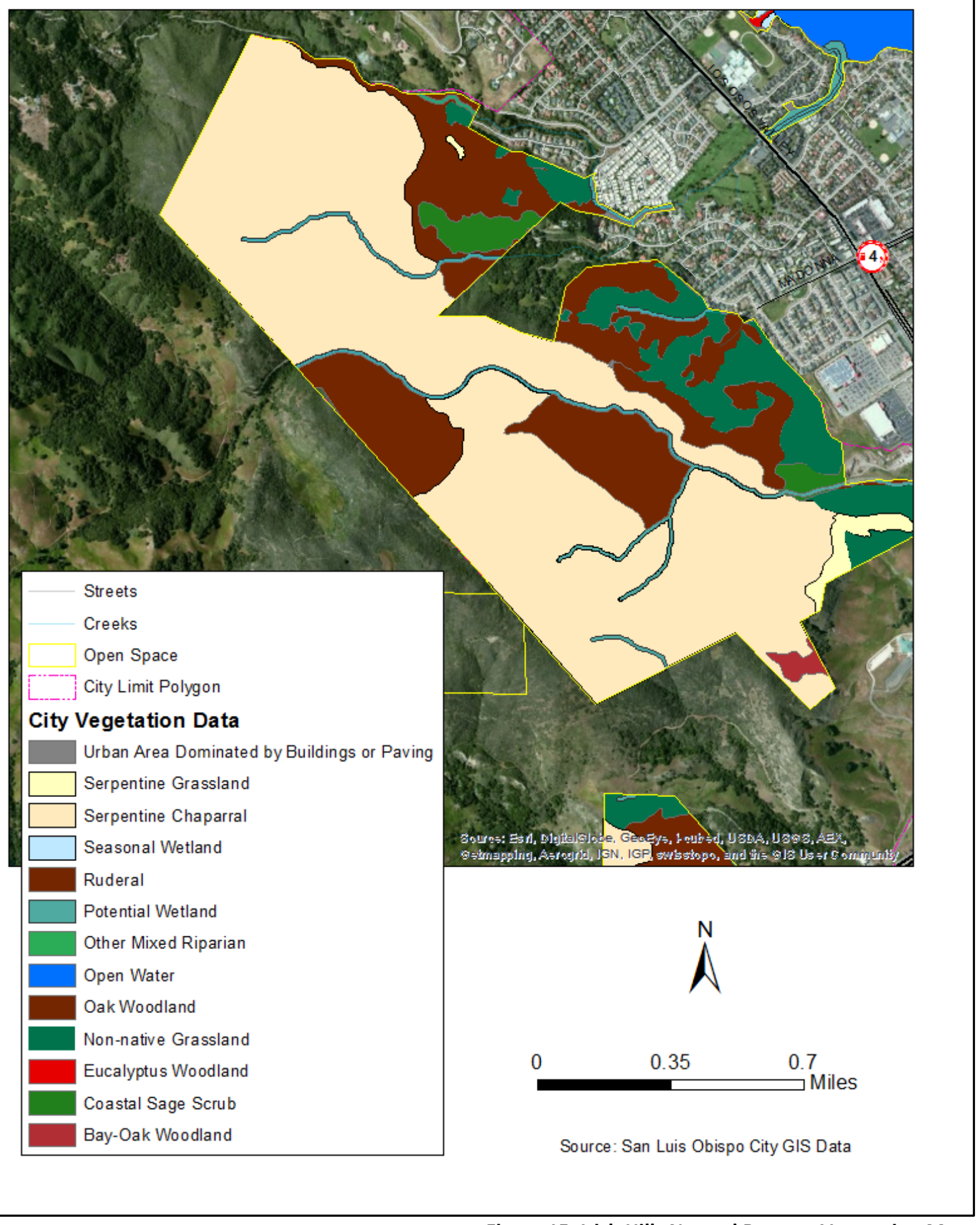

Figure 15. Irish Hills Natural Reserve Vegetation Map. 


\section{Fuel/Vegetation}

A majority of the property is covered in Serpentine Chaparral, totaling about 630 acres

Oak woodland covers about 234 acres, mostly along hillsides that face north or northeast and around riparian areas.

There are about 95 acres of Non-native Grassland along the eastern boundary

There are about 13 acres of Serpentine Grassland in the southeast corner

There are also some Potential Wetland and Riparian Habitats, covering approximately 30 acres, lining the stream banks of Perfumo Creek, Froom Creek, and the tributary of Perfumo Creek which flows past Sterling Drive.

\section{Topography}

Ranging from 140 feet to a peak elevation of 1,160 feet. There are canyons along Froom Creek and Perfumo Creek.

\section{Assets at Risk/Structures}

There are important features noted in the "Irish Hills Natural Reserve Conservation Plan Update:"

Natural Features

- Threatened Steelhead trout in the two streams

- Endangered Plant Species (Chorro Creek Bog Thistle)

- Several rare plant and animal species

- Chaparral, Oak Woodland, and Grassland on Serpentine Soils

- Four former mine sites

- Large tracts of intact, high quality wildlife habitat

Built Features

- High-tension power lines and towers owned by PG\&E

- Mines from the early 1900's. (Havlik, Otte, \& Riley, 2011, p. 2)

\section{Access}

Prefumo Canyon Trailhead: From Highway 101, take Los Osos Valley Road north towards Los Osos. Turn left onto Prefumo Canyon Road. Follow this road for one mile and the trailhead will be on the left after and bridge crossing.

Madonna Road Trailhead: From Highway 101, take Los Osos Valley Road north towards Los Osos. Turn left on Madonna Road. Follow the street to the end. There is a 16' paved access road. 
There is a paved road at the end of Sterling Drive, and it is about 14-16' wide and about 1.2 miles long and there is a steep, unpaved stretch. This access road is in need of continuous maintenance.

There is another dirt access road at the end of Isabella Way.

There is an Access Easement on the eastern part of the property and a 14' wide very steep dirt road past a combination lock.

\section{Water Supply}

Near Perfumo Canyon: At the end of Perfumo Canyon Drive there is a hydrant. There are also hydrants located along Isabella Way and at the end of Jane Drive.

Sterling Drive and Madonna Road Access: There is a hydrant located at the end of Sterling Drive, which leads to an access road. There is also a hydrant at the end of Royal Way, Partridge Drive, Quail Drive, and along Devaul Ranch Drive on the opposite side of the street and along the Park. There are also hydrants behind Costco and Home Depot.

\section{Evacuation Routes}

From Perfumo Canyon: Perfumo Canyon to Los Osos Valley Road, Del Rio Avenue to Perfumo Canyon to Los Osos Valley Road. Via Laguna Vista to Diablo Drive to Los Osos Valley Road.

From Sterling Drive and Madonna Road access: Exit Sterling Drive to Royal Way to Los Osos Valley Road. Exit Partridge Drive to Royal Way to Los Osos Valley Road. Exit Quail Drive to Royal Way north to Los Osos Valley Road. Exit Eto Circle to Madonna Road to Los Osos Valley or Madonna Road. Exit Spooner Drive or Madonna Road to Los Osos Valley Road of Madonna Road. Exit DeVaul Ranch to Los Osos Valley Road.

\section{Historical Data}

There is no history of major fires at this open space.

\section{Predominant Risk Exposure}

This area is very high risk, particularly due to the fact that there is hazardous fuel and no significant fire history. It is also located along multiple properties with risk of man-made fires from homes or visitors to the property. 


\section{Wildfire Preparedness Plan}

\section{Fire Hazard Severity Zone}

Very High Fire Hazard Severity Zone

\section{Current Pre-Fire Plan}

As per the Irish Hills Conservation Plan, there are four areas identified for wildfire preparedness:

Potential prescribed burning area - area that has a high load of vegetative fuel that could be reduced by burning.

Fuel management area - adjacent to urban/wildland interface that will require active pruning, mowing, and/or other active management of the vegetation to reduce fuel loads adjacent to developed areas.

Active firefighting area - areas acting as a buffer between the surrounding urban developments and the pristine habitat lying to the west of IHNR. Heavy machinery and cutting of fuel breaks can protect life and property from advancing wildfire.

Passive (habitat sensitive) firefighting area - areas of important wildlife habitat and are somewhat removed from urban development. Strategies in these areas should be limited to low impact methods. The city will conduct annual mowing in grassland areas behind homes on Isabella, Partridge, Eto, and DeVaul Ranch Drives at width of 20-30 feet. The city will also continue to mow the meadow at the North end of Isabella Street on an annual basis as well as conduct regular brush abatement every $5+$ years in the previously stated areas behind homes up to a distance of 200 feet from homes as deemed necessary. (Havlik, Otte, \& Riley, 2011)

Pre-fire plan would include fuel breaks, mowing, weed-whacking and clearing brush against houses. There are also peripheral shaded fuel breaks that need to be maintained.

\section{Future Considerations}

Perfumo Creek has Scotch Broom that needs to be removed.

\section{Priority Ranking: High}

Irish Hills is the most intensive fire hazard. It has both natural and man-made assets, steep slopes, as well as hazardous vegetation on the property. This open space also does not have any fire history, which could pose a higher threat. Without property vegetation management and clearance, if there were to be a wildland fire it has potential to be much more severe. 


\section{Laguna Lake Open Space Aerial Map}
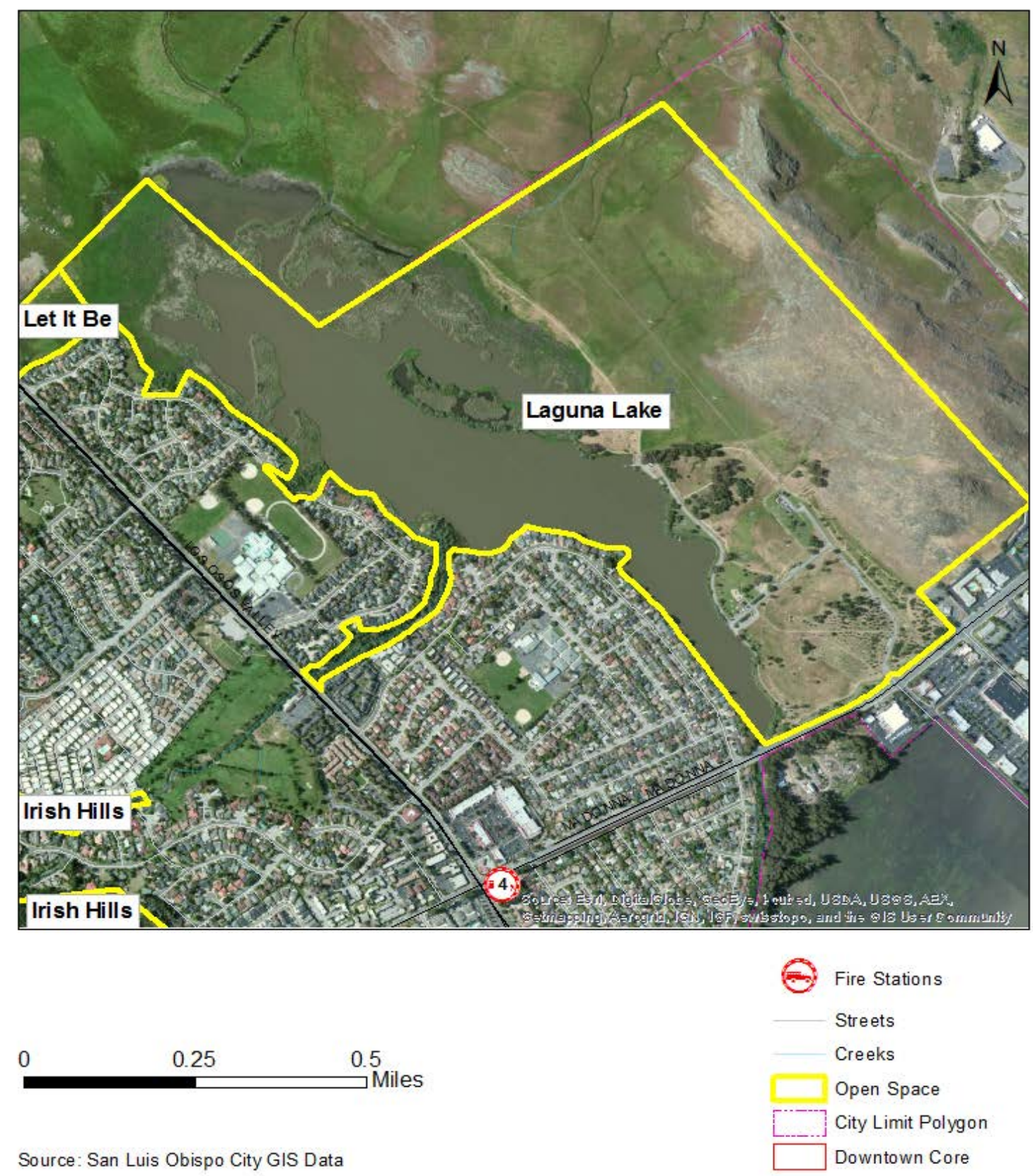

Figure 16. Laguna Lake Aerial Map. 


\section{Description}

\section{Location}

Laguna Lake is about 360 acres, the entrance is at the corner of Madonna Road and Dalidio. It is north of Madonna Road, east of Laguna Middle School and west of Dalidio.

Closest Fire Station: Fire Station 4

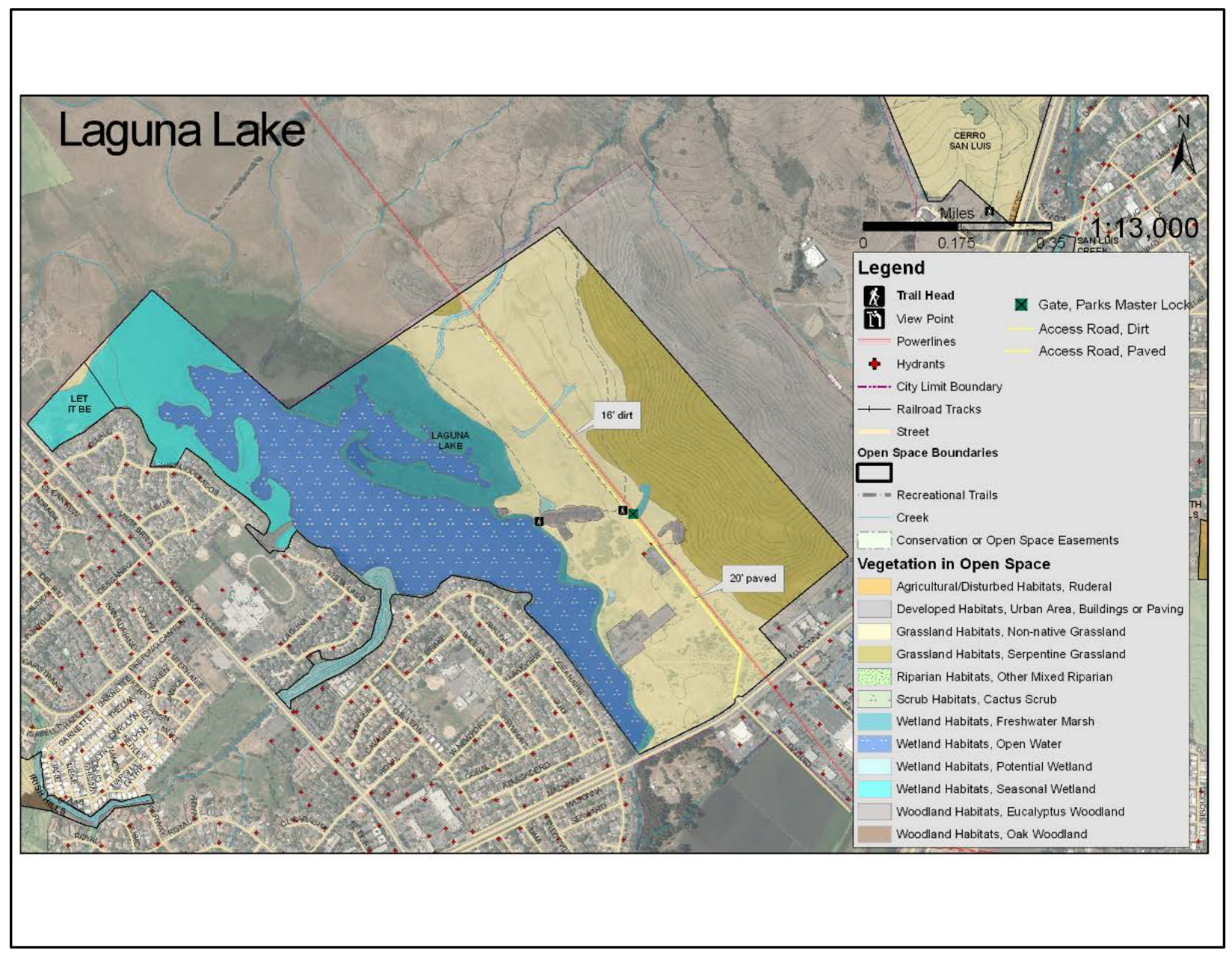

Figure 17. Laguna Lake Map. 


\section{Laguna Lake Vegetation Map}

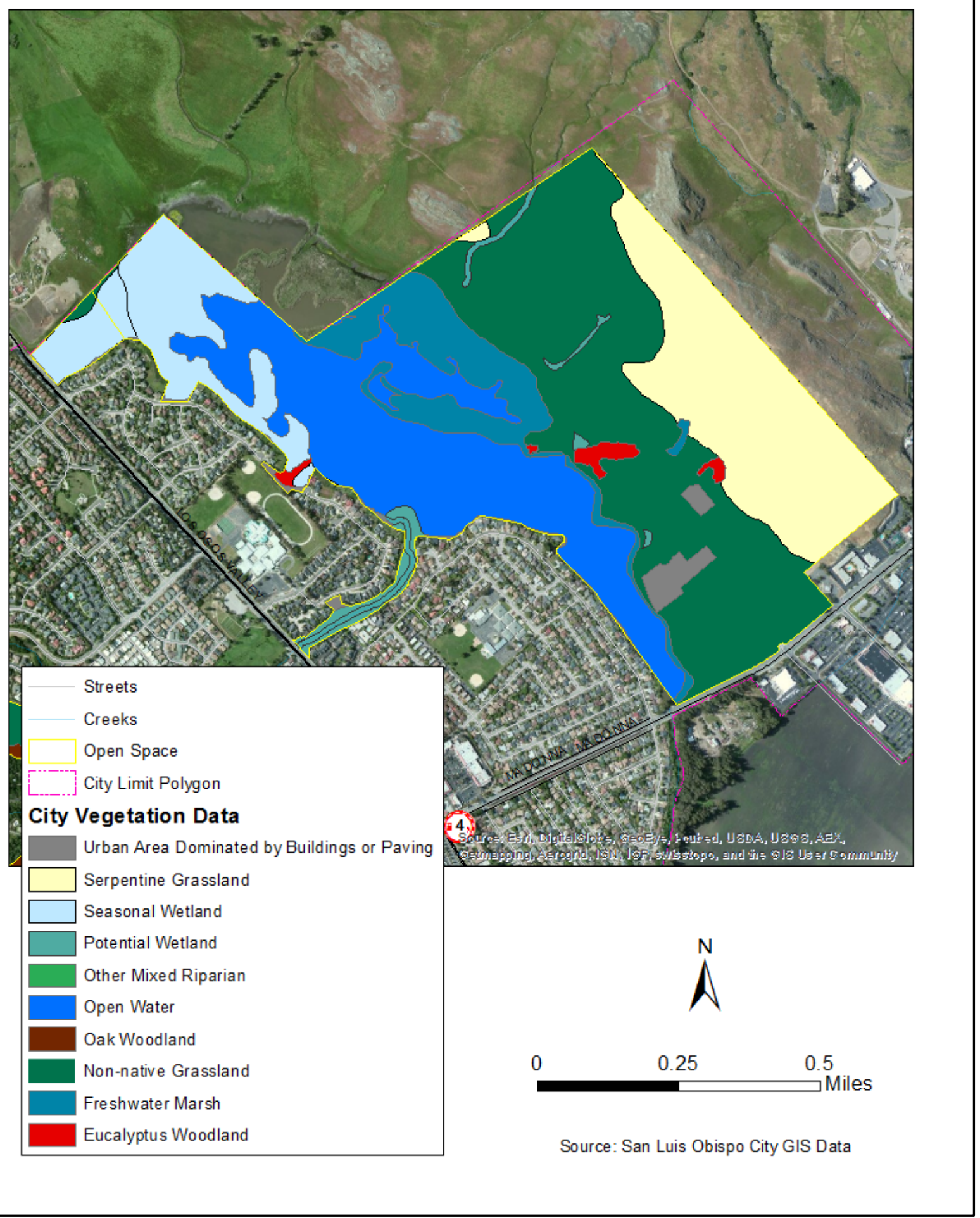

Figure 18. Laguna Lake Vegetation Map. 


\section{Fuel/Vegetation}

The western half of Laguna Lake open space is about 100 acres of open water, 35 acres of freshwater marsh, and 7 acres of potential wetland and about 42 acres of seasonal wetland.

The other half of Laguna Lake is about 203 acres of Non-native Grassland and 77 acres of Serpentine Grassland, with a few patches of Eucalyptus Woodland, totaling about 4 acres.

\section{Topography}

Elevation changes from 120-200 feet, with the hilly area on the eastern portion of the property.

\section{Assets at Risk/Structures}

- Some endangered plants are found in the open space

- Nearby residential properties, separated from the vegetation by a lake

- Hotels on the south side of the open space along Madonna Road

Access

Heading west on Madonna Road, turn right on Dalidio Drive into Laguna Lake Park.

There is an access road from Dalidio that is $20^{\prime}$ wide and paved, which leads to a locked gate and connects to a $16^{\prime}$ wide dirt road. There is also access along the lake on the east side, connecting from Dalidio Drive.

\section{Water Supply}

There are two hydrants located at the end of Dalidio before the gate access to the dirt road. Additionally, the lake could be used for helicopter access to water if necessary.

There are also hydrants located along the roads adjacent to Laguna Lake on the western side.

Lastly, there are hydrants located along Madonna Road behind the hotels adjacent to the southeastern boundary.

\section{Evacuation Routes}

Evacuation would take place from the main driveway out of Dalidio to Madonna Road.

\section{Historical Data}

There is no history of major fires at this open space.

\section{Predominant Risk Exposure}

There is a high risk of human caused ignition on this property. There is also potential for ignition from the power lines that cross the open space. 


\section{Wildfire Preparedness Plan}

\section{Fire Hazard Severity Zone}

There is a Moderate Fire Hazard Severity Zone nearby, however, there is no overlap.

\section{Current Pre-Fire Plan}

There is no prescription for Laguna Lake Open Space, as it isn't an immediate threat or a high priority. The Parks and Recreation Department is responsible for mowing, and there is weed whacking which takes place behind the hotels. There is also a limited grazing regime to reduce the heights of the grasses in the meadow.

\section{Future Considerations}

The areas with larger trees in the riparian areas as well as the eucalyptus trees near the peninsula should be monitored and managed to reduce fuel hazards. Lastly, the area adjacent to the boat launch should be mowed in the spring and early summer as well as any dead or downed trees should be removed.

\section{Priority Ranking: Low}

The grassland vegetation which is a majority on this property does not pose a high risk, so long as there is continued monitoring and managing of the larger trees and eucalyptus, as well as continuous annual mowing and weed whacking to the meadow and the power lines are maintained properly. 


\section{South Hills Open Space Aerial Map}
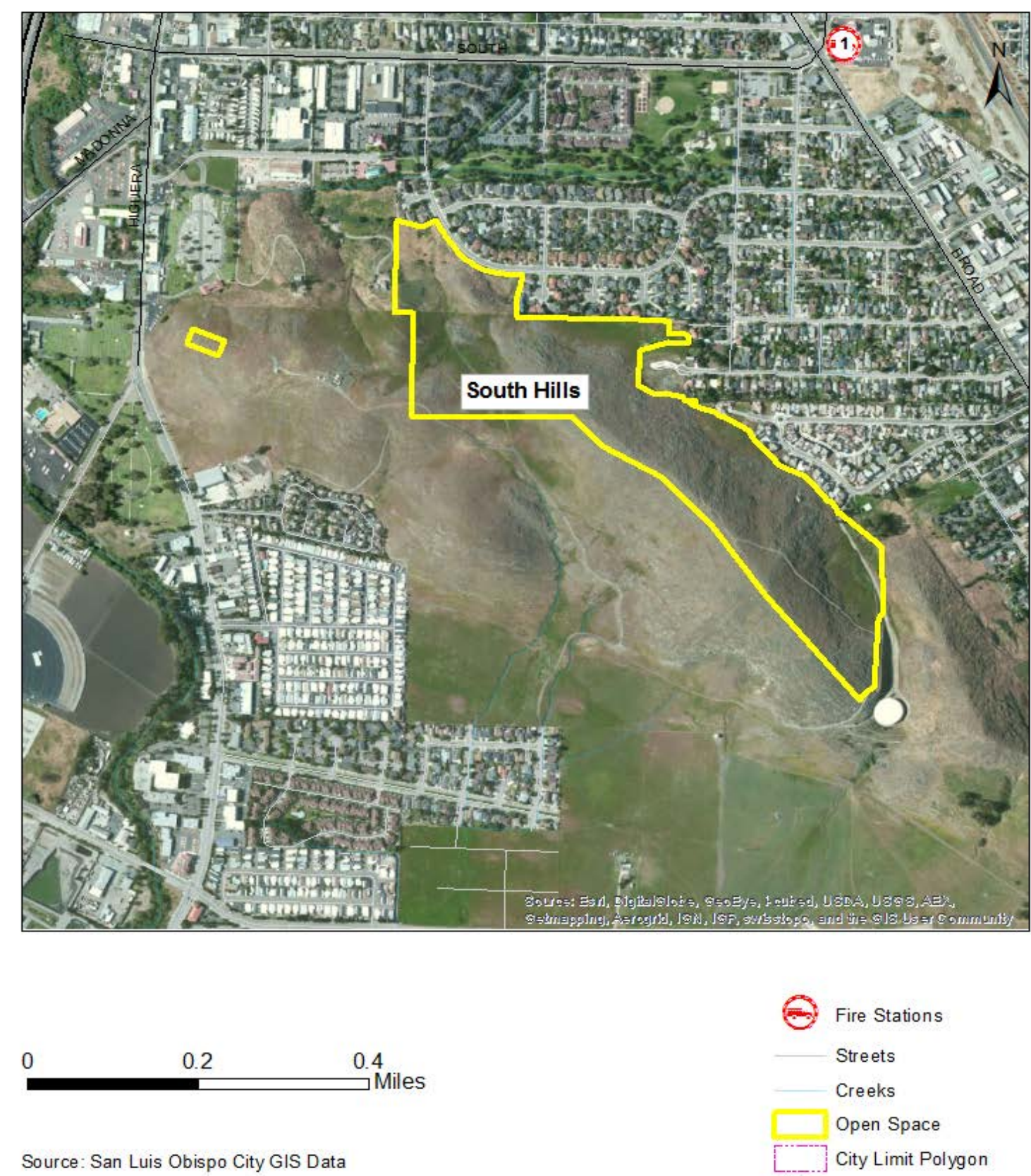

Figure 19. South Hills Aerial Map. 


\section{Description}

\section{Location}

South Hills Natural Reserve is approximately 131 acres bordered by the Woodbridge and Stoneridge developments to the north and the new Margarita Area Development will boarder along the south.

Closest Fire Station: Fire Station 1

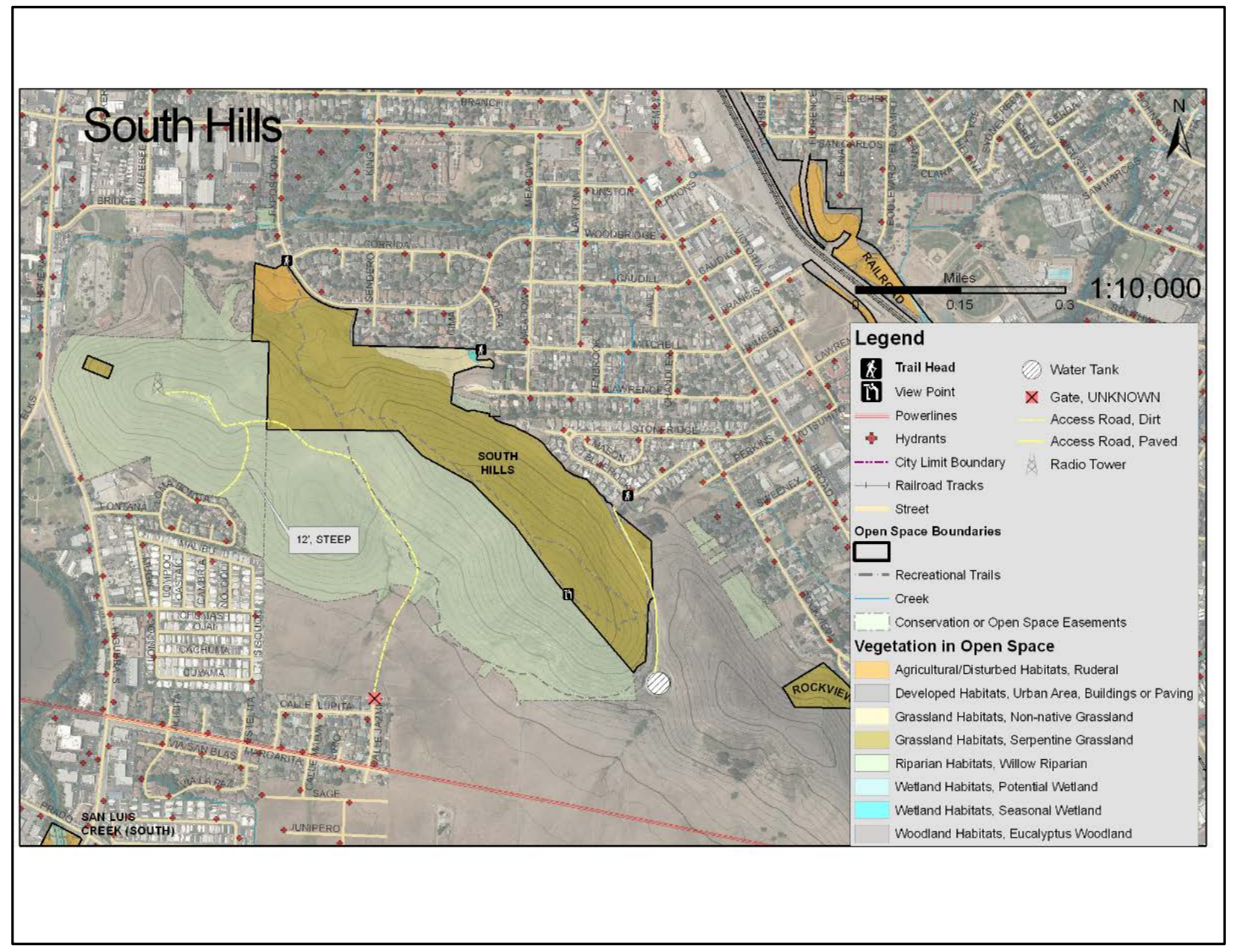

Figure 20. South Hills Map.

*Note: "UNKNOWN" gate is a Parks Master Lock 


\section{South Hills Vegetation Map}

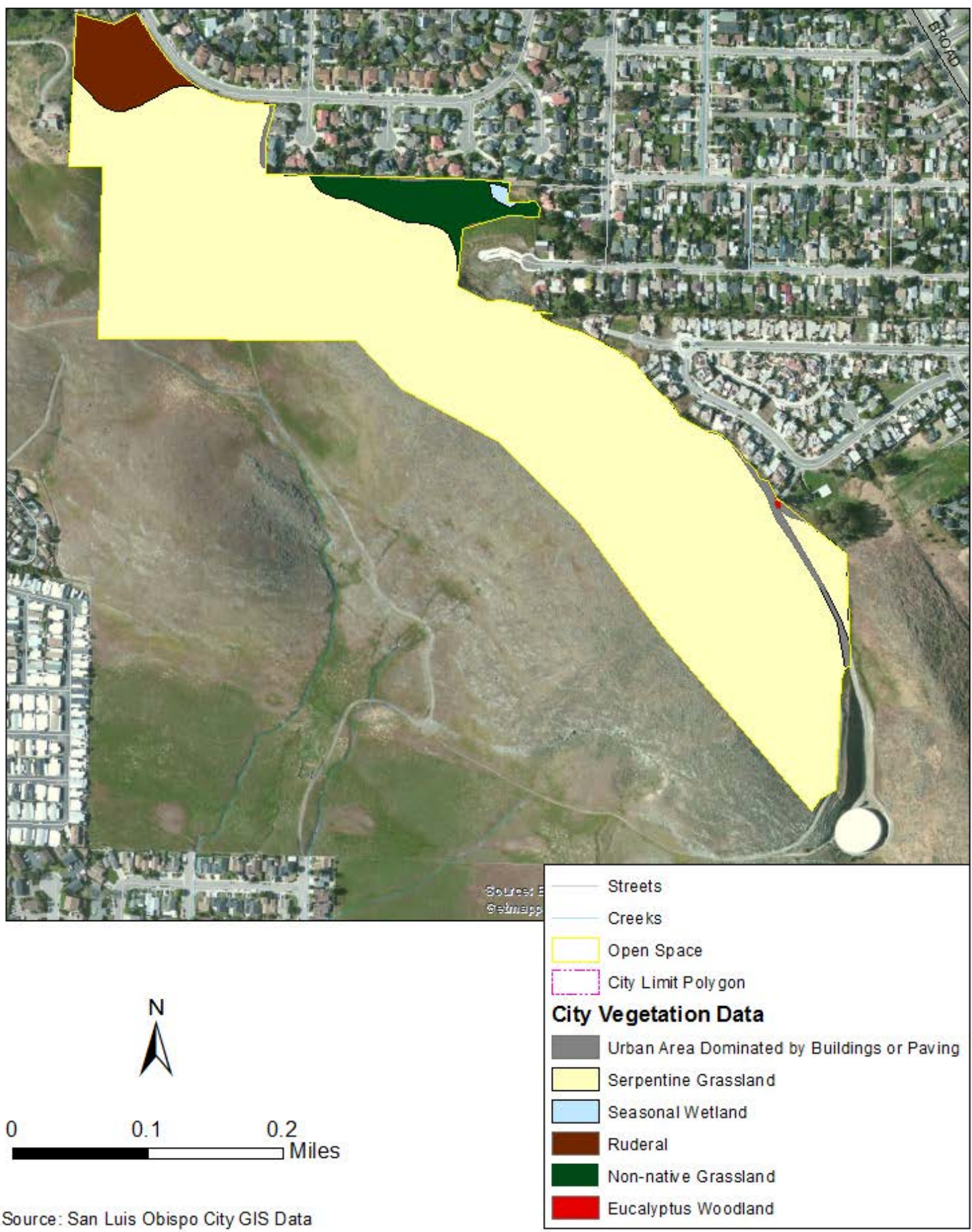

Figure 21. South Hills Vegetation Map. 


\section{Fuel/Vegetation}

South Hills is mostly serpentine grassland and annual grasslands.

Serpentine Grassland covers about 58 acres. Non-native Grassland is about 3 acres. The northernmost section of property of 3 acres is Agricultural/Disturbed habitats. There is also a small seasonal wetland on the eastern edge adjacent to the non-native grassland. There are a few small patches of Eucalyptus woodland on the eastern edge and southeast edge of the property.

\section{Topography}

Elevation ranges between 200 and 575 feet. It's a series of short ridges of serpentine running in a northwest-southeast direction with a saddle area in between the two ridges.

\section{Assets at Risk/Structures}

- Surrounding neighborhoods adjacent to the property

- Communication towers on the western summit

- Water tank southeast of the property

\section{Access}

Woodbridge Trailhead: Take South Street east and turn right onto Exposition Drive. Go straight and the road turns into Woodbridge Street. The trailhead is on the right.

Bluerock Trailhead: Taking Broad Street south, turn right onto Stoneridge Road. Go through a round-about and turn left onto Bluerock Drive. Trailhead is located just behind the Stoneridge Park on the right. This serves as a maintenance road for the City's water tank and for emergency vehicle access. There is an unpaved fire road that breaks off the paved road to the water tank and bisects the property to serve as an access road to the communication site located on the ridge above the "saddle" area on private property (Havlik \& Otte, 2007).

There is also 4wd access on Calle Yasmine to the South.

There are two more access points proposed with the approved development.

There is access at Fontana to the south, leading to the radio and cell towers.

\section{Water Supply}

Hydrants are located at Calle Jazmin at Calle Lupita at the south access, Across from Stoneridge Park on Bluerock at the east access, along Woodbridge on the north, and along South Higuera and Loma Bonita on the west access. 


\section{Evacuation Routes}

Margarita west to South Higuera; Woodbridge east to Meadow to South Street; Woodbridge west to Exposition to South Street; Bluerock and Stoneridge to Broad Street; Bridge (not accessible for Engine, only auto) to west to Higuera.

\section{Historical Data}

There is no history of major fires at this open space.

\section{Predominant Risk Exposure}

Major risks of ignition to this property would be from adjacent residential property, human causes, or from power lines which are south and run parallel to the Open Space.

\section{Wildfire Preparedness Plan}

\section{Fire Hazard Severity Zone}

Not located in a Fire Hazard Severity Zone

\section{Current Pre-Fire Plan}

As stated in the "South Hills Natural Reserve Conservation Plan:"

Since there is basically no brush to be controlled or modified for fire protection purposes at SHNR, wildfire preparedness will concentrate on ensuring that emergency access designated in the Conservation Plan will be able to serve those needs, and that a minimum 20 foot mowed buffer will be maintained on the perimeter of the Reserve where it is adjacent to developed property. Some adjacent developments are already required to do such work, but in some places this requirement is not in effect, and City staff will ensure that this program is carried out in those areas. (Havlik \& Otte, 2007, p. 18).

There is currently weed whacking the northern border. Additionally, cell phone towers on private property through a conservation easement.

\section{Future Considerations}

Margarita Specific Plan is on the southern boarder; once this comes in there should be a fence constructed. There is currently livestock permitted since the Open Space is not fenced off from the private property on the south. Eventually, livestock grazing will no longer be permitted.

\section{Priority Ranking: Low}

South Hills Natural Reserve is comprised of mostly flashy fuels without an imminent fire threat and can be maintained. Management, such as maintaining emergency access roads and a buffer, should be continued. 


\section{Bishop Peak Open Space Aerial Map}
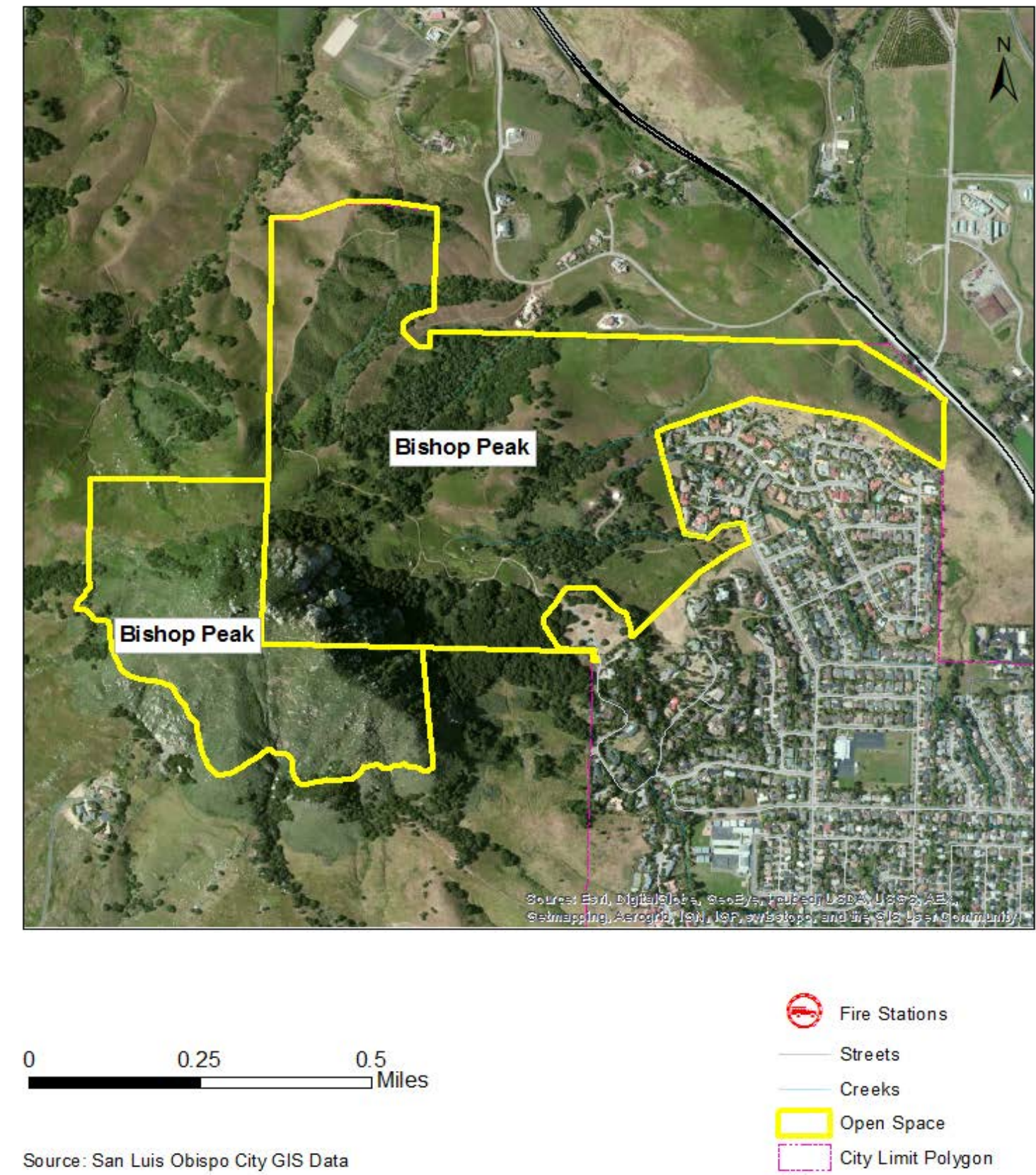

Figure 22. Bishop Peak Aerial Map. 


\section{Description}

\section{Location}

Bishop Peak Natural Reserve is 352 acres. It is in both the City and County Limits in the northwest portion of San Luis Obispo. It is south of Highway 1 and north of Foothill Boulevard, with Patricia Drive on the east side.

\section{Closest Fire Station: Fire Station 2}

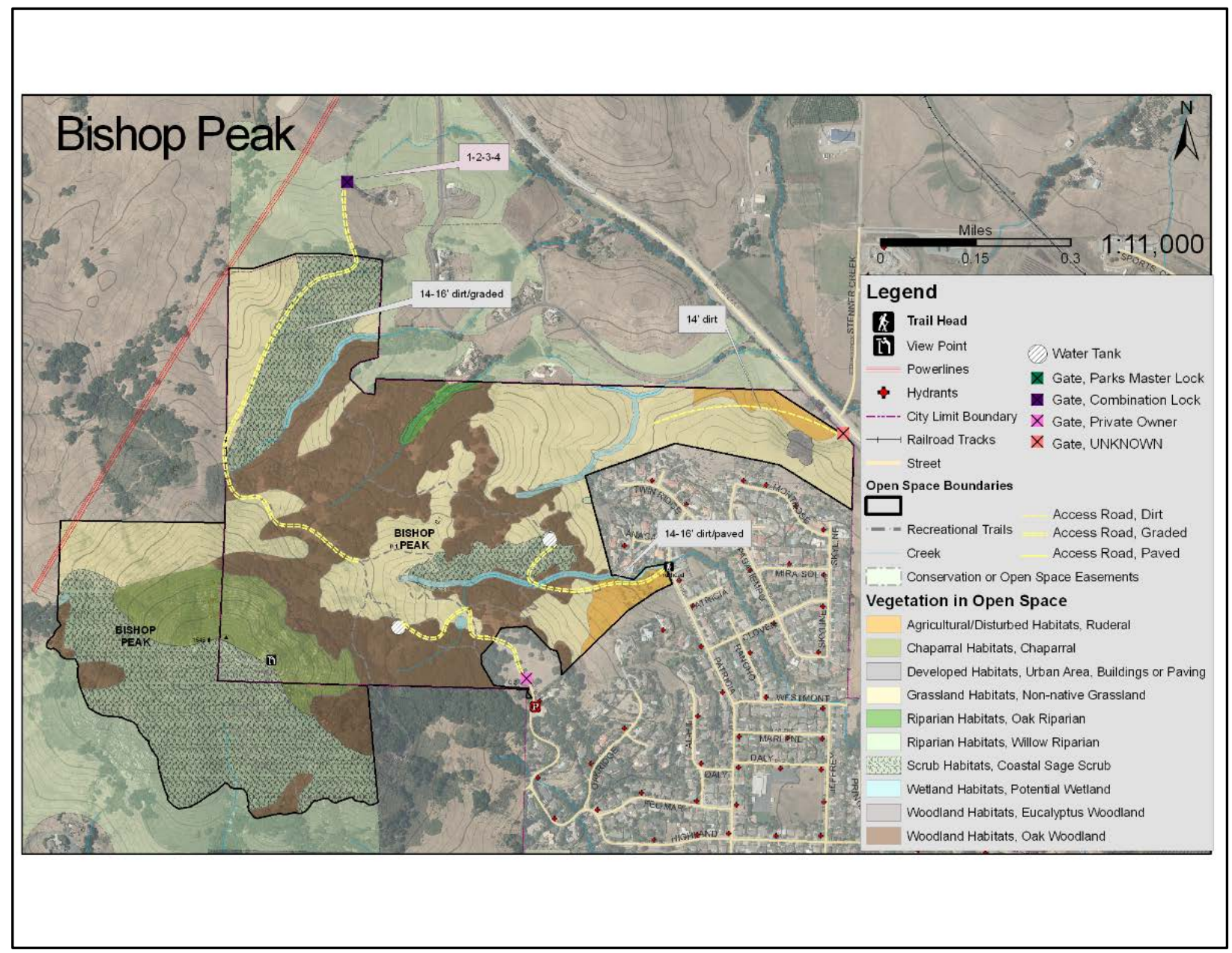

Figure 23. Bishop Peak Map. *Note: "Unknown Gate" is a Parks Master Lock 


\section{Bishop Peak Vegetation Map}

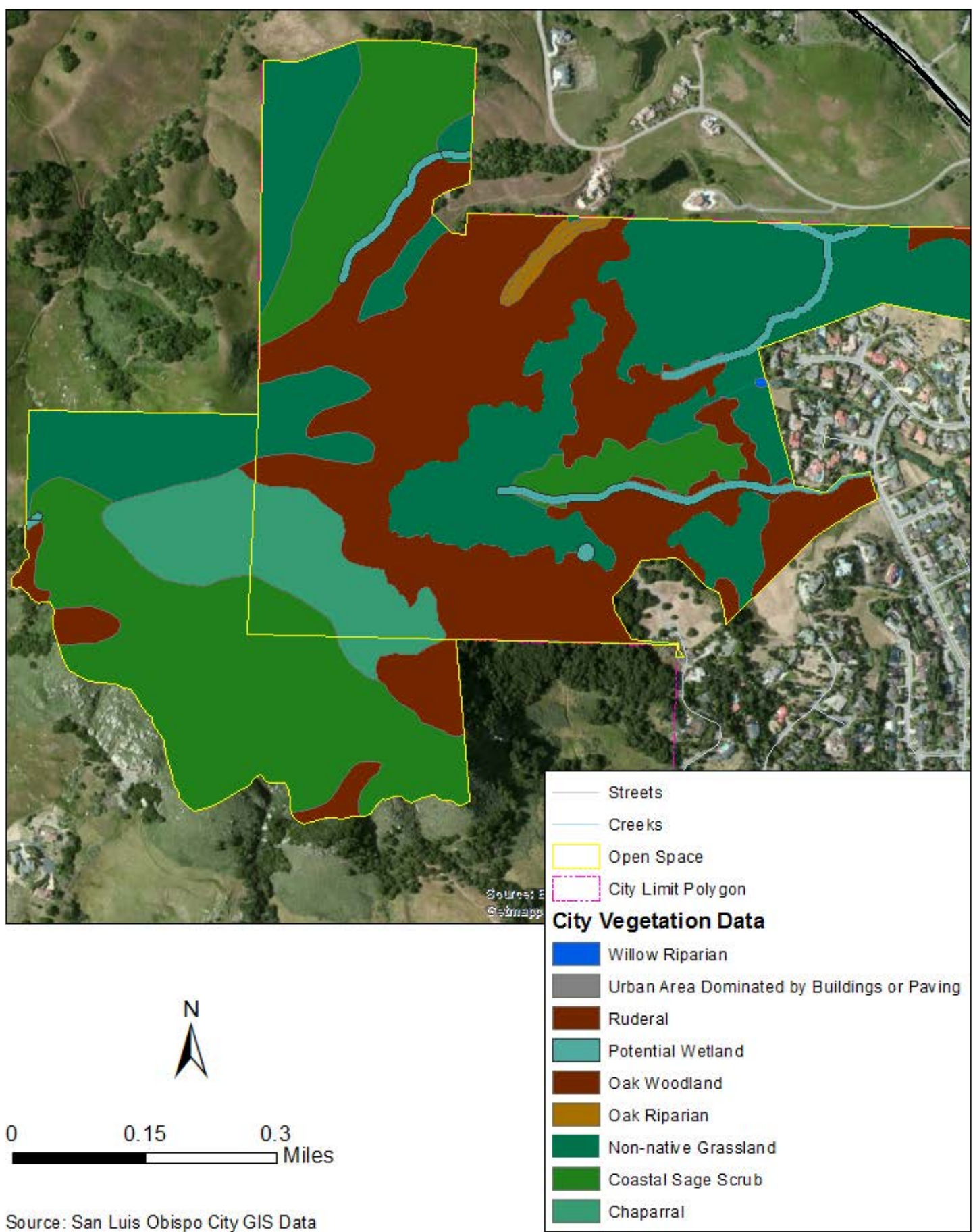

Figure 24. Bishop Peak Vegetation Map. 


\section{Fuel/Vegetation}

Oak Woodlands cover about 100 acres in the center of the property, on the north and east facing hillsides and swales.

There are about 101 acres of Non-native Grasslands.

Coastal Sage Scrub is found in the northern, southern, and western areas, totaling about 83 acres.

Chaparral covers 25 acres.

Potential Wetlands run on the eastern portions of the property along creeks, totaling about 6 acres.

Topography

Elevation from about $550 \mathrm{ft}$. to $1559 \mathrm{ft}$. at the peak

Assets at Risk/Structures

- Neighborhoods north and east of the Open Space

- Two water tanks located on the property

\section{Access}

Patricia Avenue: Heading west on Foothill Boulevard, turn right onto Patricia Drive. Follow Patricia Drive and just after Patricia Court is the trailhead on the left. 14-16' dirt and paved road leading up to a water tank. Used for maintenance or emergency services.

Highland Drive: Heading west on Highland Drive up to Brittany Circle leads to an as an access road which leads up to a water tank.

Highway 1 gate: Emergency services access and cattle access only. Private Owner Gate to a $14^{\prime}$ wide dirt road.

Bishop Peak Ranch Northern Gate: Not open to the public. Emergency and maintenance. 14-16' dirt/graded road.

Bishop Peak Ranch Southern Gate: Not open to the public. Movement of cattle, pedestrian emergency services and maintenance.

Bishop Peak Ranch Middle Gate: Not open to public. Movement for cattle, pedestrian emergency services and maintenance. 


\section{Water Supply}

There are hydrants located on Brittany Circle off of Highland Drive as well as along Patricia, including near the trailhead south of Anacapa Circle.

There is a hydrant at the end of Anacapa Circle, and at the corner of Twin Ridge Drive and Twin Ridge Court to the north. There are also hydrants located along Montrose Drive.

Another hydrant is located at the end of Clover Drive off of Patricia Drive.

\section{Evacuation Routes}

From the north, take Patricia Drive South, then east on Highland Drive.

From the south, take Brittany Circle south, then east on Highland Drive.

Take Oakridge Drive south to Highland Drive east.

\section{Historical Data}

Colony Fire, 2003

Bishop Peak Fire, July 16, 2013

\section{Predominant Risk Exposure}

Bishop peak is a highly active recreation site, with high risk of human cased ignition. It also has power lines that run along the western portion of the property. Lastly, it is adjacent to numerous residential properties to the east and north.

\section{Wildfire Preparedness Plan}

\section{Fire Hazard Severity Zone}

High Fire Hazard Severity Zone

Moderate Fire Hazard Severity Zone on the boarder of the property

\section{Current Pre-Fire Plan}

As per the "Bishop Peak Natural Reserve Conservation Plan," five areas have been identified for vegetation management procedures:

Potential Prescribed Burning Area - areas identified as supporting a high load of vegetative fuel that could be safely reduced by burning under prescribed weather and wind conditions.

Fuel Management Area - areas adjacent to the urban/wildland interface that could not be safely burned in a controlled manner. These areas will require active pruning, 
mowing, and/or other active management of the vegetation (including livestock grazing) to reduce fuel loads adjacent to developed properties

Active Firefighting Area - areas acting as a buffer between the surrounding urban developments and the pristine habitat lying to the west but still within the BPNR. Active firefighting techniques such as the use of heavy machinery and cutting of fuel breaks can be used to isolate property from an advancing wildfire. These areas have also been identified because the physical resources and topography are conducive to successful restoration efforts following a wildfire.

Passive (habitat sensitive) firefighting area - areas of important wildlife habitat, mostly on steep hillsides. These areas are also somewhat removed from urban development. They are particularly sensitive to aggressive firefighting techniques such as the use of heavy machinery. Therefore, wherever practicable, firefighting strategies in these areas should be limited to low impact, habitat friendly methods.

Construction of continuous emergency maintenance road - at the present time, vehicular access to portions of BPNR which experience high maintenance and occasional emergency access is poor. This is particularly problematic in the area of the pond. A $1 / 4$ mile of new jeep road connecting to the upper Bunnel Road to the road from Brittany Court (Highland Drive), which reaches Highway 1, will be constructed. This will create a continuous emergency/maintenance road access across the property. Due to two recent fires on the open space and the level of heavy use the area receives, City staff believe that construction of this portion of the access road is essential ensure the continued safety of people using the reserve (Havlik \& Clarke, 2004, pp. 35-36).

This has been constructed for the most part, but the entire alignment has not been made.

Additionally, there is annual mowing treatment, and areas adjacent to residential properties require active mowing, thinning, and reduction of fuel loads.

There is a fire break that needs to be maintained on the Felsman Loop back bridge.

\section{Future Considerations}

The continuous emergency management road should be completed in the future.

The fire break on the Felsman Loop back bridge also needs to be maintained in the future.

Livestock grazing could also be utilized, as per the Conservation Guidelines for Bishop Peak Natural Reserve (BPNR). This would be permitted on the Ferrini Open Space portion and will be divided by fencing into upper and lower pastures. The upper pasture will allow livestock grazing during the growing season from March 15 to around June 15. The lower pasture will allow 
livestock grazing from approximately March 15 to November 1 . Therefore, there will be no livestock grazing from approximately November 1 to March 15. (Havlik \& Clarke, 2004).

\section{Priority Ranking: High}

Due to Fire History, assets at risk, vegetation on the property such as chaparral, steep slopes, and minimal escape routes from the property, Bishop Peak is a High priority ranking. 


\section{Reservoir Canyon Natural Reserve Aerial Map}
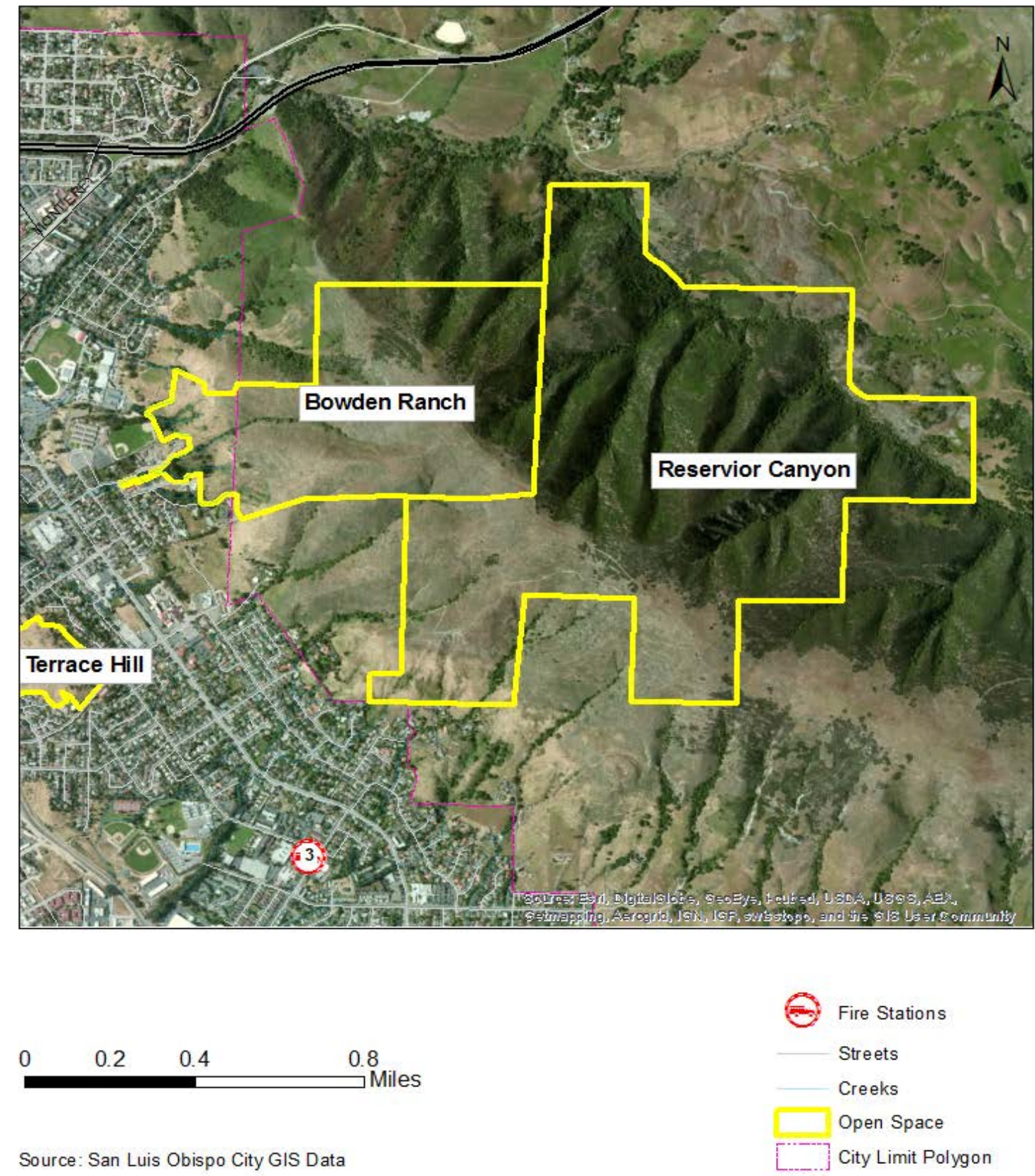

Figure 25. Reservoir Canyon Natural Reserve Aerial Map. 


\section{Description}

\section{Location}

Reservoir Canyon Natural Reserve is about 800 acres, located off Highway 101 northeast of the city. It contains Reservoir Canyon Open Space on the east and Bowden Ranch Open Space on the West. It is owned by the city, yet located in the County's jurisdiction.

Closest Fire Station: Fire Station 3

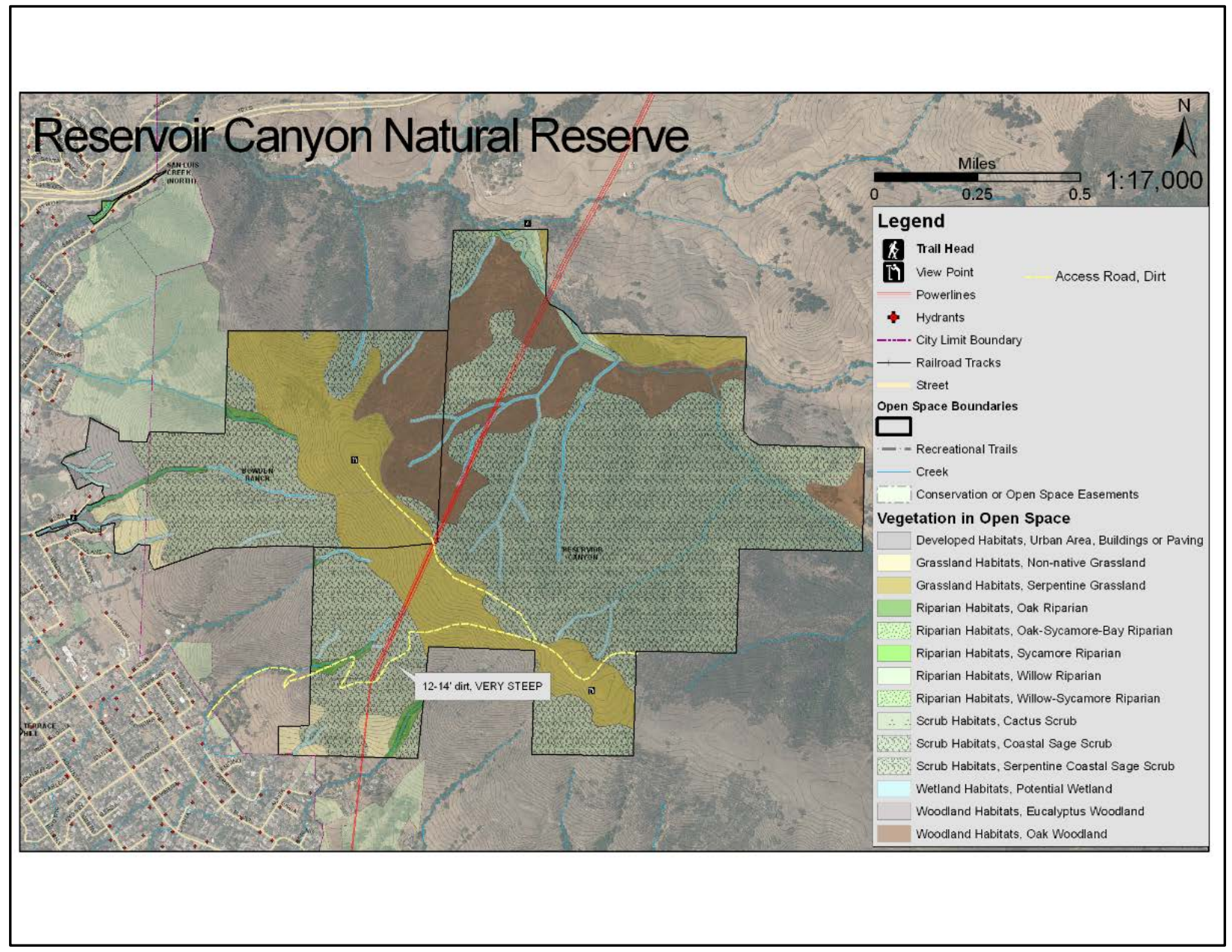

Figure 26. Reservoir Canyon Natural Reserve Map. 


\section{Reservoir Canyon Natural Reserve Vegetation Map}

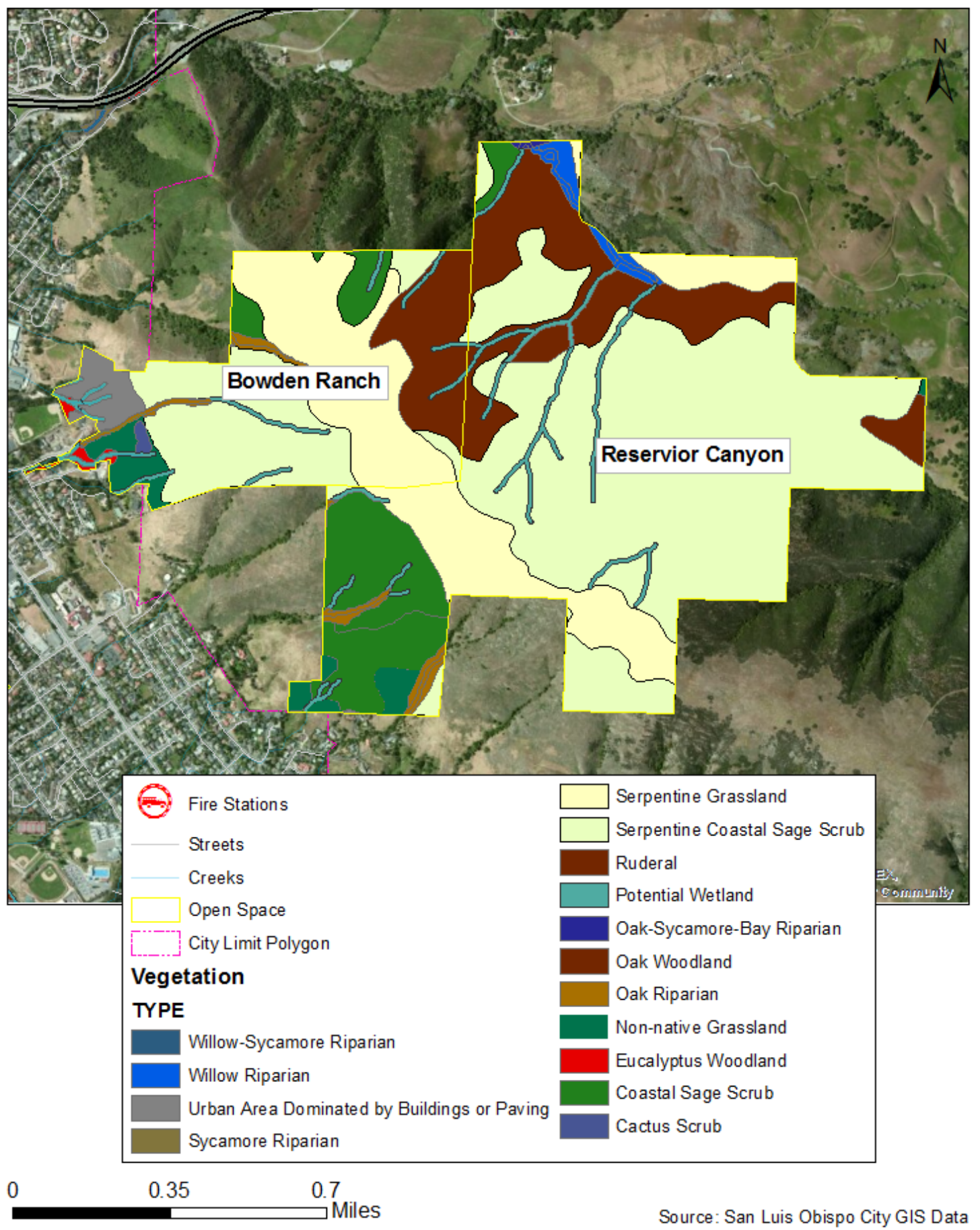

Figure 27. Reservoir Canyon Natural Reserve Vegetation Map. 


\section{Fuel/Vegetation}

There are a few habitats found in the Reservoir Canyon Natural Reserve, including Serpentine Coastal Sage Scrub, Oak Woodland, Serpentine Grassland, and Coastal Sage Scrub.

A majority of both properties is Serpentine Coastal Sage Scrub, covering about 400 acres.

There is also about 75 acres of Coastal Sage Scrub, found at the northern portion of both Open Spaces, as well as the southwestern portion of Reservoir Canyon Open Space.

About 110 acres of Oak Woodland is found in the northern part of the canyon, with Willow Riparian and other potential wetland habitat following the creeks.

There are two perennial creeks which are fed by springs and seeps along the ridge, which leads to riparian habitats at the bottom of the canyon (Havlik, Hill, Otte, \& Provenzale, 2013). These Riparian habitats and Potential Wetlands lead to about 2 acres of Eucalyptus Woodlands.

There are about 140 acres total of Serpentine Grassland, which runs along the northern portion of Bowden Ranch and down through to the southeastern portion of Reservoir Canyon, as well as the northern portion of Reservoir Canyon above the Oak Woodlands.

Coastal Sage Scrub takes up approximately 75 acres in the southwestern part of Reservoir Canyon as well as a few patches in the northern portions of Bowden Ranch and Reservoir Canyon.

In the western portion of Bowden Ranch, there are almost 10 acres of Non-Native Grassland Habitat and about 8 acres of Oak Riparian Habitat and Potential Wetlands. Lastly, there is about an acre of Cactus Scrub habitat.

\section{Topography}

Ranges from 400 feet to 1,715 feet of mostly steep terrain.

\section{Assets at Risk/Structures}

- Lizzie St. Neighborhood

- Surrounding neighborhoods to the west and south of the Open Space

- La Loma Adobe has historical significance and is proposed to be included in the Reservoir Canyon Natural Reserve

\section{Access}

Access at the north entrance is from Reservoir Canyon Road, one mile north of the City of San Luis Obispo limits, east off of Highway 101.

There is another access point off of the top of Lizzie Street through the Bowden Ranch Open Space entrance. 
There is a $12-14^{\prime}$ very steep dirt access road from the end of Sydney Street.

\section{Water Supply}

There are hydrants located on Lizzie Court, Woodland Court, and Woodland Drive. There are also hydrants located along Flora Street, Sunset Drive, and at the end of Sydney Street.

\section{Evacuation Routes}

Lizzie Court west and then north on Johnson Avenue, Woodland Court to north on Wilding Lane and west on Lizzie Street.

Head southwest on Sydney Street and north on Johnson Avenue.

\section{Historical Data}

Las Pilitas Fire in July of 1985 , burned a total of 75,000 acres in the county

Highway 41 in 1994

Highway 58 in 1996

Johnson Fire, 2007 (Bowden Ranch)

Bowden Ranch Fire, August 27, 2013 (Bowden Ranch)

\section{Predominant Risk Exposure}

There are power lines which traverse through the Natural Reserve, which is a risk for potential ignition. Additionally, Highway 101 is located northwest of the property, with risk for ignition from motor vehicles. Lastly, there are residential properties against the property as well as the risk from humans.

\section{Wildfire Preparedness Plan}

\section{Fire Hazard Severity Zone}

Very High Fire Hazard Severity Zone

High Fire Hazard Severity Zone

Moderate Fire Hazard Severity Zone

\section{Current Pre-Fire Plan}

As stated in the Reservoir Canyon Natural Reserve Conservation Plan, the Natural Reserve is owned by the city, yet mostly in County Jurisdiction. Additionally, most of the land is in the State Responsibility Area. The City's primary responsibility area is the portion of the boundary which contains Eucalyptus groves near the Bowden Ranch entrance to the property. The Conservation Plan also states that "these groves will continue to be managed with safety pruning and selection removal over time in order to allow younger oak trees light and space to grow, while maintaining the tree canopy of the larger eucalyptus trees that provide the character and backdrop to the neighborhood. These activities will be undertaken outside of 
nesting bird season and with notice to neighbors unless an imminent safety hazard is determined" (Havlik, Hill, Otte, Provenzal, 2013, p. 23)

There should be continuous thinning behind homes as needed, especially in the Eucalyptus grove behind Taylor Field with access through school district property.

Access is limited to some of the property; therefore more fire suppression would potentially be from the air.

\section{Future Considerations}

There is a shaded fuel break at Bowden Creek which gets maintained every three years and is going to be continued in the winter of 2014-2015.

Continued thinning behind homes, especially in the Eucalyptus grove behind Taylor Field.

There should also be a focused outreach with the Lizzie Street neighborhood to address concerns with vegetation management and educate the community on ways to manage risks and steps that the City is taking to ensure public safety and natural resources protection.

\section{Priority Ranking: High}

Due to the fire hazard, fire history, assets at risk, and steep topography of the area, Reservoir Canyon Natural Reserve is a High priority for the City to manage. 


\section{Stenner Springs Open Space Aerial Map}
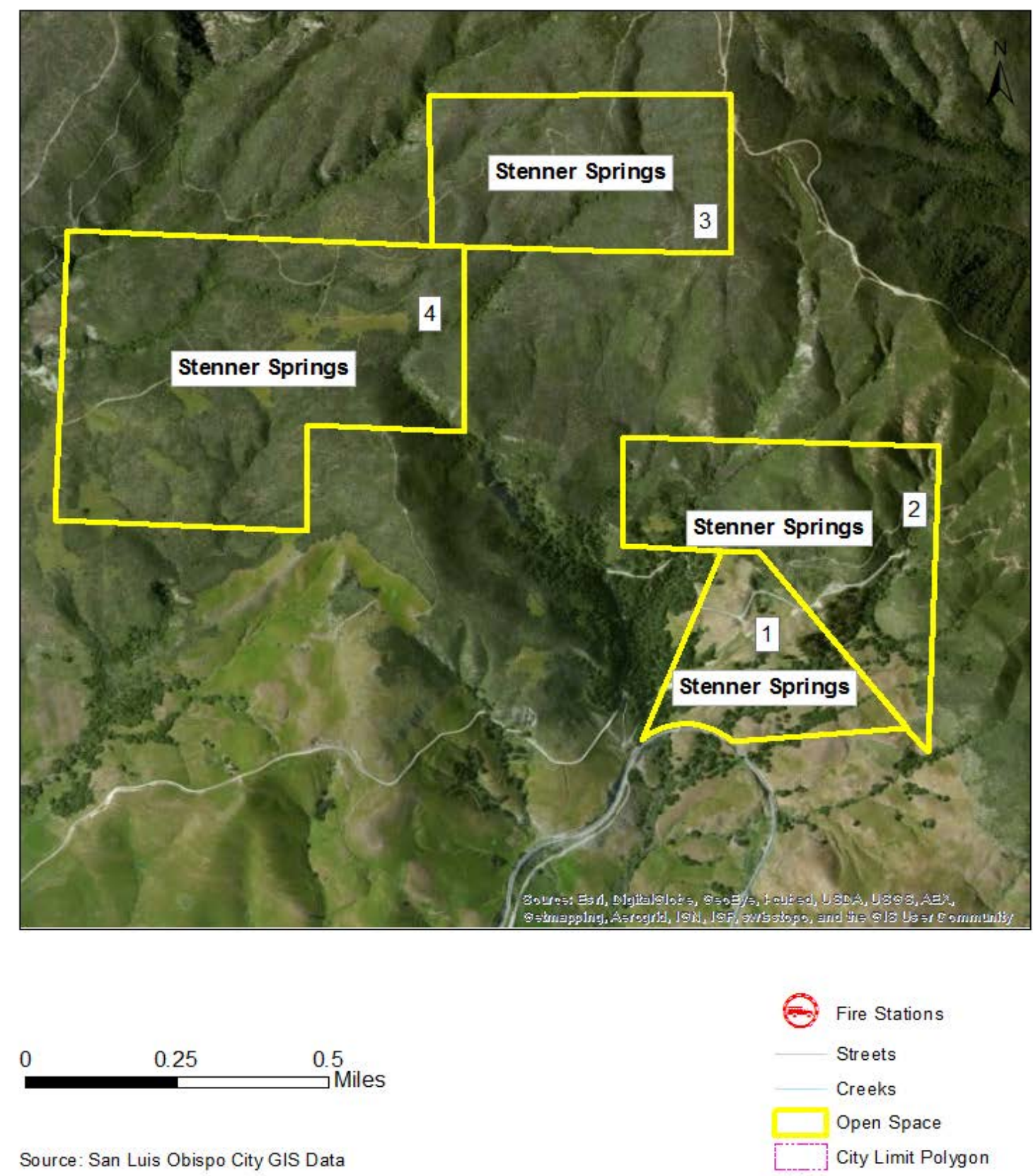

Figure 28. Stenner Springs Aerial Map. 


\section{Description}

\section{Location}

Stenner Springs is about 365 acres divided into four parcels, located partially within and partially adjacent to Los Padres National Forest in Stenner Creek Canyon, about four miles north of the City of San Luis Obispo. It's bordered by the US Forest Service, Cal Poly, Camp San Luis Obispo, and a private property known as Stenner Ranch. The property is about four miles north of the City of San Luis Obispo.

\section{Closest Fire Station: Fire Station 2}

Ownership: two sections are Conservation Easements held by the Land Conservancy; one parcel is $50 \%$ ownership with the state of California

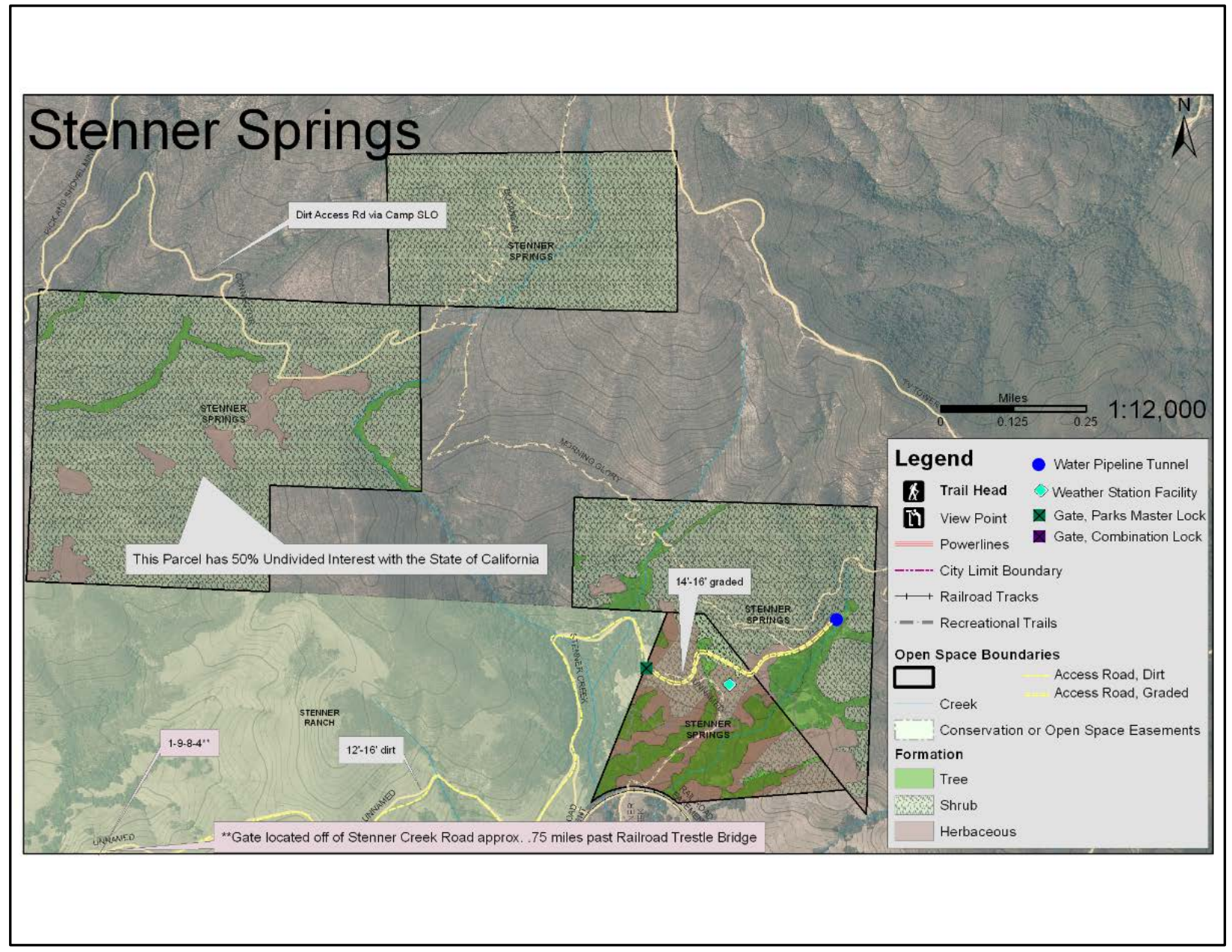

Figure 29. Stenner Springs Map. 


\section{Stenner Springs Vegetation Map}

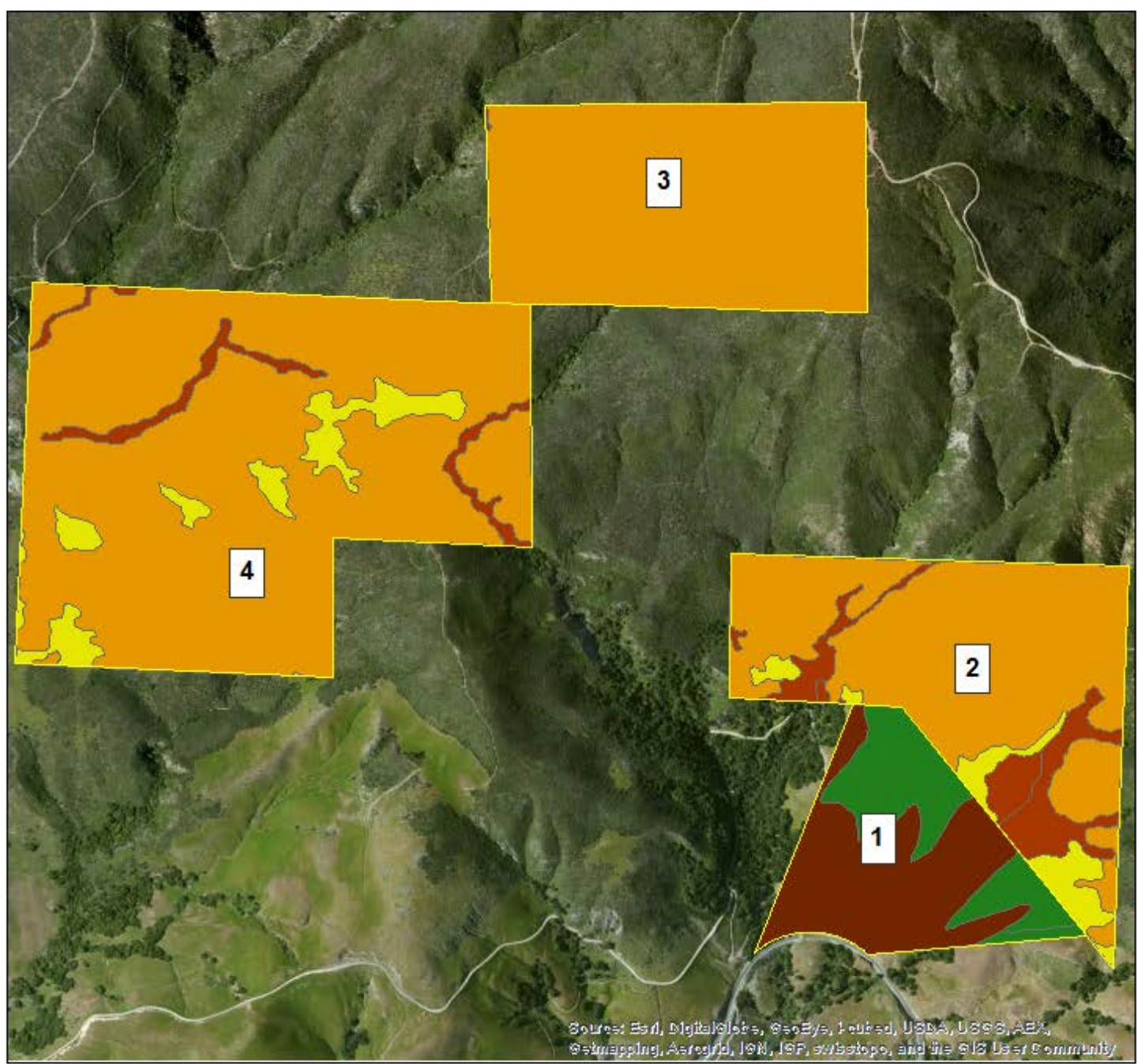

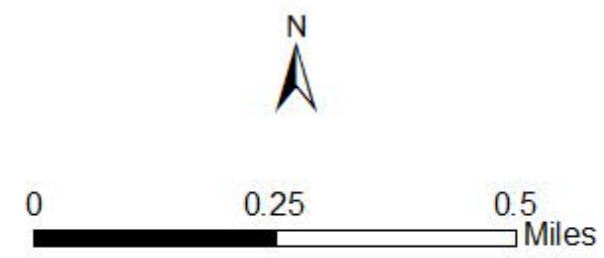

Source: San Luis Obispo City and County GIS Data

\begin{tabular}{|l|l|}
\hline Streets & \multicolumn{1}{c|}{ County Vegetation File } \\
Creeks & Forest \& Woodland \\
\hline Open Space & Mixed Chaparral \\
\hline City Limit Poly gon & Coastal Grassland \\
City Vegetation File & \\
Oak Woodland \\
Coastal Sage Scrub
\end{tabular}

Figure 30. Stenner Springs Vegetation Map. 


\section{Fuel/Vegetation}

The City GIS Data was not available for the entire section of Stenner Springs, therefore the County GIS Vegetation Data and information from the Stenner Springs Conservation Plan was used for analysis.

A majority of the properties are shrubland and grassland, which is specified in the Conservation Plan as chaparral and coastal scrub.

There are also some patches of coastal grassland, or serpentine bunchgrass found on parcels 2 and 4.

There are also oak woodlands occurring along waters and in lower elevations of the parcels.

There are two planted eucalyptus groves which cover about four acres, and that have a dense understory.

Wetlands of springs and waterways with Sargent Cypress are found on parcels 3 and 4. A much larger strand of Sargent Cypress is on the National Forests Land directly north of parcel 3.

\section{Topography}

Elevations range from 900 to 2200 feet above sea level

\section{Assets at Risk/Structures}

- Multiple sensitive and rare plant and animal species, such as the endangered California Red-legged frogs

- City and state water and a water pipeline tunnel

- Weather station facility

- Fire Communication

\section{Access}

Eastern access: take US Highway 101 north from San Luis Obispo to the top of Cuesta Grade. Head west on TV Tower Road about one mile to mountain bike train "Shooters" and 2.5 miles to hiking trails "Morning Glory" and "Botanical."

Southern access: head west out of San Luis Obispo on Highway 1 towards Morro Bay, slightly less than a mile outside of town turn right onto Stenner Creek Road. Follow Stenner Creek Road for about 2.5 miles to the end. There is a gate located off of Stenner Creek Road approximately 0.75 miles past Railroad Thistle Bridge, which leads to a 12-16' dirt access road up to Stenner Springs Property in the southern parcel. There is another Gate and a 14-16' graded access road which leads to the Water Pipeline Tunnel.

Vehicular access for maintenance purposes is available through Camp San Luis Obispo on a dirt access road from the west. 


\section{Water Supply}

There are no fire hydrants located in close proximity to Stenner Springs.

\section{Evacuation Routes}

TV Tower Road east to US Highway 101 north or south.

Stenner Creek Road south to Highway 1.

\section{Historical Data}

Unnamed fire in 1939.

HWY 41 Fire was a major fire in 1994, but the health of the vegetation is considered very good and almost in full recovery.

\section{Predominant Risk Exposure}

Major risks to this area are from recreational users, railroad tracks, and power lines.

\section{Wildfire Preparedness Plan}

\section{Fire Hazard Severity Zone}

Very High Fire Hazard Severity Zone

Moderate Fire Hazard Severity Zone

\section{Current Pre-Fire Plan}

Livestock grazing is currently permitted from the adjacent Cal Poly lands to the south.

As noted in the Wildfire Preparedness Plan section of the Stenner Springs Conservation Plan, this property "is located in such a remote location without an immediate wildland urban interface, therefore management is deferred to the county and a specific Wildfire Preparedness Plan isn't necessary. However, access for fire and safety vehicles should be maintained" (Havlik, Otte, \& Lloyd, 2007, p. 24).

\section{Future Considerations}

Interagency coordination is necessary for this property, especially considering its proximity to other agency's responsibility areas.

\section{Priority Ranking: Medium}

Stenner Springs has chaparral, oak woodland, and eucalyptus groves, which are hazardous, as well as risk from nearby vehicular traffic, recreational users, and risk from the railroad and power lines. Stenner Springs is a high priority when taking into account critical infrastructure and fire hazards. There is significant potential for loss of property. However, from a Wildland Urban Interface perspective, this area is not a high priority due to its separation from urban 
areas. Additionally, this Stenner Springs is found in a State Responsibility Area, and CAL FIRE can use fees for fuel breaks in this area, and projects should be collaborated on with City staff. Therefore, Stenner Springs is considered a High Priority to manage, but the management should be done through interagency coordination and the City should initiate interagency projects. 


\section{Priority Raking of Open Spaces}

The City should address Open Spaces that are seen as a High Priority first, and determine the best management plans, utilizing a master timeline of projects for each Open Space. It would be ideal to create a timeline of projects that should take place and potential costs far in advance of fire season. It would also be beneficial to be prepared for potential setbacks such as waiting for obtainment of grant resources or environmental considerations such as nesting season.

Open Spaces with a High Priority Ranking:

- Johnson Ranch

- Cerro San Luis

- Irish Hills

- Bishop Peak

- Reservoir Canyon

Open Spaces with a Medium Priority Ranking:

- Stenner Springs

Open Spaces with a Low Priority Ranking:

- Terrace Hill

- Laguna Lake

- South Hills

\section{Community Outreach Suggestions}

All of the wildfire preparedness plans that are ongoing and that have been proposed through Open Space Conservation Plans have gone through considerable community outreach and received public input. However, it is still important to communicate with local residents, especially those who use the areas for recreation and those who live adjacent to the property. When projects such as trimming or removal of trees or chemical management are utilized, it is necessary to inform and educate local residents on the necessity of the project and precautions that have been taken to ensure that both the public and natural resources are protected. Some suggested methods of outreach could be informational brochures provided for residents at their homes, holding informational meetings, or having an active website that addresses vegetation management projects that are occurring in their neighborhood. 


\section{Fiscal Statement}

There are costs associated with each project for the vegetation management. Natural Resources Program has funds in its operating budget. Ranger Services also has funds available in its operating budget. Parks and Maintenance (Public works) has some funds in its budget. City Fire Department has money in fire budget, as well as FireSafe Council grants, and as well as Mutual Aid Resources though CAL Fire. 
The City Fire Department can effectively manage the risk of wildland fires in the City Open Space Property through pre-fire planning and vegetation management, therefore reducing the risk of loss of life, property, and resources from wildland fires. There are necessary precautions that should be taken into account such as nesting season and sensitive biological species, and projects should be done in collaboration with the City of San Luis Obispo Natural Resources Department.

The next step would be to secure funding for projects and develop a master timeline of projects which includes every open space, based upon this management plan. It is important to simultaneously be communicating with and informing local residents on large-scale projects.

The City should update this Plan as necessary, and reflect and evaluate effectiveness of the vegetation management projects that are implemented, subsequently revising procedures as best seen fit. 


\section{References}

Blonski, K., Miller, C., \& Rice, C. L. (2010). Managing fire in the wildland interface. Point Arena, California: Solano Press Books.

CAL FIRE. (2013). [Map of fire history in San Luis Obispo County May 28, 2014]. Fire History Data from San Luis Obispo County GIS Data. Retrieved from Shape File: CF_FIRE_HISTORY.

California Department of Forestry and Fire Protection (2000, April). Property Inspection Guide. Retrieved from CAL FIRE:

http://cdfdata.fire.ca.gov/pub/fireplan/fpupload/fppguidepdf38.pdf

City of San Luis Obispo. (2014). San Luis Obispo Municipal Code. Code Publishing, Inc. San Luis Obispo, CA. Retrieved from http://www.codepublishing.com/ca/sanluisobispo/

City of San Luis Obispo. (2014). City of San Luis Obispo draft local hazard mitigation plan. Retrieved from website: http://slocity.org/cityclerk/agendas/2014/020414/ph4localhazardmitigationplan.pdf

City of San Luis Obispo. (2010). City of San Luis Obispo Zoning Regulations. City of San Luis Obispo Community Development Department. Retrieved from http://www.slocity.org/communitydevelopment/download/Zoning\%20Code\%202010Complete\%20Document.pdf

County of San Luis Obispo. (2008). [Map of vegetation for the County of San Luis Obispo]. Vegetation Shape File from San Luis Obispo County GIS Data. Retrieved from Shape File: PLN_VEG_SLOCO_2007

Havlik, N. \& Clarke, M. (2005). Cerro San Luis Natural Reserve Conservation Plan. City of San Luis Obispo Natural Resources Protection Program. San Luis Obispo, CA.

Havlik, N., Hill, R.A., Otte, F., \& Provenzale, B.. (2013). Reservoir Canyon Natural Reserve Conservation Plan. City of San Luis Obispo Natural Resources Protection Program. San Luis Obispo, CA.

Havlik, N., Otte, F., Riley B. (2011). Irish Hills Natural Reserve Conservation Plan Draft 2011 Update. City of San Luis Obispo Natural Resources Protection Program. San Luis Obispo, CA. 
Havlik, N., Otte, F., Lloyd, J. (2007). Stenner Springs Natural Reserve Draft Conservation Plan. City of San Luis Obispo Natural Resources Protection Program. San Luis Obispo, CA.

Havlik, N. \& Otte, F. (2008). Conservation Plan for the Johnson Ranch Open Space. City of San Luis Obispo Natural Resources Protection Plan. San Luis Obispo, CA.

Havlik, N. \& Otte, F. (2007). South Hills Natural Reserve Conservation Plan. City of San Luis Obispo Natural Resources Protection Plan. San Luis Obispo, CA.

United States Department of Agriculture, Forest Service. (2002). Vegetation management planning guide: Planning and implementation for developed sites in region 2. Retrieved from website: http://www.fs.usda.gov/Internet/FSE_DOCUMENTS/fsbdev3_038983.pdf 


\section{Discrepancies in Data}

\section{GIS Data for City Vegetation}

The data has been clipped to the open space. When figuring out acreage of an area of vegetation that runs outside the open space boundaries, the amount of acres states the total of that section, not necessarily the section within the boundary of the open space. Therefore, there was a column added to the attribute table and the acres were recalculated based on the boundaries of the Open Spaces. However, it is important to note that these acres were sometimes off and exact estimates should be used with discretion.

Another inconsistency in the data was that some of the Conservation Plans explained the vegetation for certain Open Spaces based upon the County GIS Vegetation Data, which is not as accurate or specific as the City GIS Vegetation Data. In an effort to make the most accurate portrayal of the vegetation, the City GIS Vegetation Data was used wherever possible. The discrepancies and inconsistencies are as follows:

- Johnson Ranch Open Space Conservation Plan has Vegetation Communities based upon 2007 data from the County GIS shape file. For the purposes of this plan, the City GIS Vegetation shape file was used.

- Additionally, there were discrepancies in the amount of acres of vegetation in certain open spaces from GIS data and Conservation Plans information. For example, Irish Hills Natural Reserve Conservation Plan Update has different acres of the vegetation than found on the City GIS Data. The plan states that serpentine Chaparral covers most of the property, covering 832 acres, and the GIS data has 631 acres. The plan also states that Oak Woodland habitat covers approximately 166 acres, and GIS data said 234 acres. Lastly, Non-native Grassland covers approximately 74 acres based on the Conservation Plan, and the GIS Data stated it was about 96 acres. These inconsistencies could be a variation from the GIS data or from analysis from different years, as vegetation can change over time. There is also the possibility that one vegetation survey is more accurate than another.

It is recommended that the City maintain consistency in the future with analysis of vegetation and note where the information is being obtained. 